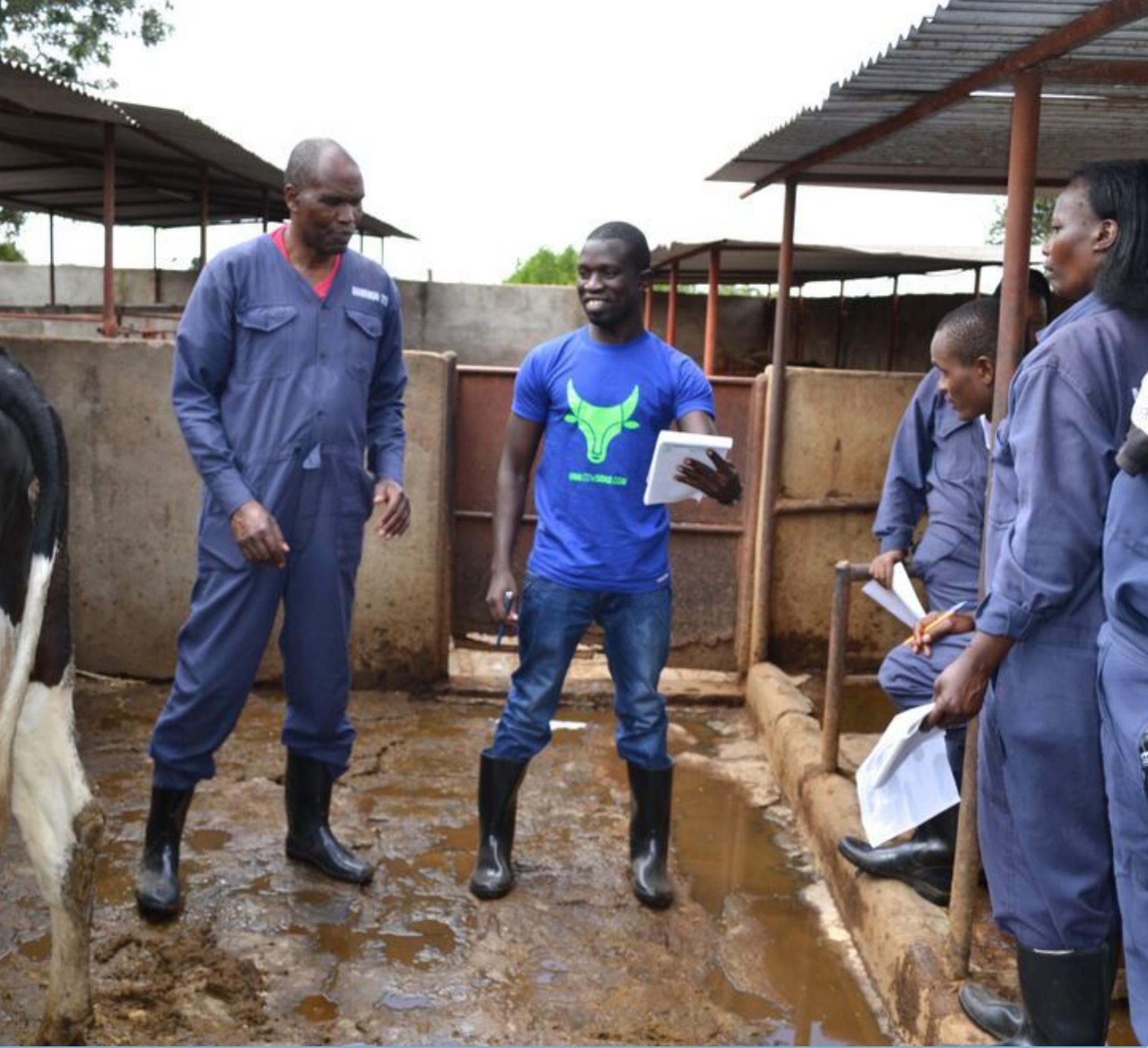

Emerging private extension and advisory services models in the Kenyan agrifood sector: Selected case studies 



\section{Emerging private extension and advisory services models in the Kenyan agrifood sector: Selected case studies}

Gerald Mutinda Katothya ${ }^{1}$, Catherine W. Kilelu ${ }^{2}$, Gregory Sikumba ${ }^{3}$ and Jan van der Lee ${ }^{4}$

1.Jomo Kenyatta University of Agriculture and Technology

2.3R Kenya project coordinator, African Centre for Technology Studies

3.Dicova Africa Group Consulting Limited

4. Wageningen Livestock Research 
Katothya, Gerald Mutinda, Kilelu, Catherine W., Sikumba, Gregory and van der Lee, Jan. 2020. Emerging private extension and advisory services models in the Kenyan agrifood sector: Selected case studies. 3R Kenya Report 013, Wageningen Livestock Research Report 1258, Wageningen UR, Wageningen.

Photo credits frontpage: Victor Otieno/CowSignals

\section{Summary}

The role of the private sector in delivering agricultural extension and advisory services (AEAS) is of interest in relation to agrifood systems transformation in most developing countries. This study examined four private AEAS models that have emerged in the Kenyan agrifood sectors toward sustainable commercialisation with a focus on dairy and horticulture. The study assessed the design and operational features of the models and how they perform as agri-service enterprises, in contributing to farm improvements and financial sustainability of the focal firms' core businesses. The findings highlight both similarities and differences in design and operationalization features of the models. The assessment shows mixed results in terms of their performance in delivery and uptake of extension services with some attention to being inclusive, revenue generation and financing, and benefits of extension to the focal firms' core business and farmers. Stimulating market demand for the services and getting the financing model right are identified as the most critical success factors in establishing and scaling such models.

This report can be downloaded for free at https://doi.org/10.18174/523776 or at www.wur.nl/livestock-research (under Wageningen Livestock Research publications).

\section{(C) 2020 Wageningen Livestock Research}

P.O. Box 338, 6700 AH Wageningen, The Netherlands, T +31 (0)317 483953 , E info.livestockresearch@wur.nl, www.wur.nl/livestock-research. Wageningen Livestock Research is part of Wageningen University \& Research.

All rights reserved. No part of this publication may be reproduced and/or made public, whether by print, photocopy, microfilm or any other means, without the prior permission of the publisher or author.

Wageningen Livestock Research is NEN-EN-ISO 9001:2015 certified.

All our research commissions are in line with the Terms and Conditions of the Animal Sciences Group. These are filed with the District Court of Zwolle. 


\section{Table of contents}

$\begin{array}{ll}\text { Table of contents } & 3\end{array}$

$\begin{array}{ll}\text { Abbreviations and acronyms } & 6\end{array}$

$\begin{array}{ll}\text { Acknowledgements } & 7\end{array}$

$\begin{array}{ll}\text { Executive summary } & 9\end{array}$

$1 \quad$ Introduction $\quad 11$

$\begin{array}{lll}1.1 & \text { Background } & 11\end{array}$

$\begin{array}{ll}1.2 & \text { Analytical framework } \\ & 12\end{array}$

1.3 Methodology 13

2

Case 1: Mazao Safi private extension services model 15

$\begin{array}{lll}2.1 & \text { About the business } & 15\end{array}$

2.2 Design of Mazao Safi private extension services model $\quad 15$

2.3 Evaluating performance of the model from the supply- side (business model) $\begin{array}{ll}\text { perspective } & 18\end{array}$

2.4 Evaluating performance of extension services from the demand-side perspective

2.5 Conclusions and recommendations on MS model 23

$\begin{array}{lll}3.1 & \text { About the business } & 25\end{array}$

3.2 Design of Instaveg's outgrower embedded extension model 25

3.3 Evaluating performance of Instaveg's extension service from the supply-side $\begin{array}{ll}\text { perspective } & 29\end{array}$

3.4 Evaluating performance of Instaveg's extension services from the demand-side perspective $\quad 30$

3.5 Conclusions and recommendations on the Instaveg model 34

4.1 About the business $\quad 35$

4.2 Design of PAL's private dairy advisory services model 35

4.3 Evaluating performance of PAL's advisory services from the supply-side $\begin{array}{ll}\text { perspective } & 39\end{array}$

4.4 Evaluating performance of PAL's advisory services from the demand-side perspective

4.5 Conclusions and recommendations on the PAL model $\quad 45$

5.2 Design of the NKCC milk supply chain-embedded advisory model 46

5.3 Evaluating performance of the NKCC model from the supply-side perspective 50 
5.4 Evaluating performance of the NKCC dairy advisory model from the demand-side $\begin{array}{ll}\text { perspective } & 52\end{array}$

$\begin{array}{lll}5.5 & \text { Conclusions and recommendations } & 55\end{array}$

6.1 Design and operationalisation features $\quad 57$

6.2 Performance from the focal firms' business perspective 59

6.3 Performance from farmer clients' perspective 59

$\begin{array}{lll}6.4 & \text { Recommendations } & 59\end{array}$

\section{References}

\section{Tables}

Table A: Key characteristics of AEAS models studied and fieldwork regions $\ldots \ldots \ldots \ldots \ldots \ldots \ldots \ldots \ldots . \ldots$

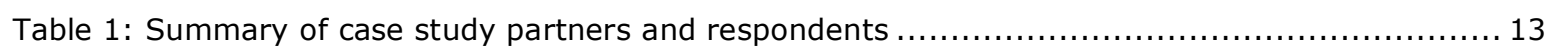

Table 2: A profile of Mazao Safi's services package, costing and delivery approaches ................... 16

Table 3: Profile of technical advisors based at the Mazao Safi Embu field hub .......................... 17

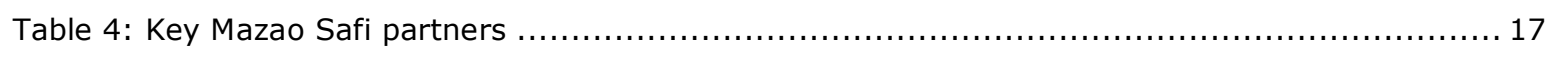

Table 5: Key lessons learned on the design and operationalisation of the MS model $\ldots \ldots \ldots \ldots \ldots \ldots \ldots$

Table 6: Revenue projections and interim performance experiences - Mazao Safi ....................... 19

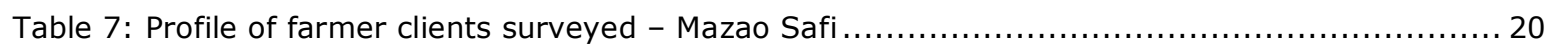

Table 8: Negative attributes about main sources of farming advice and information - Mazao Safi..... 21

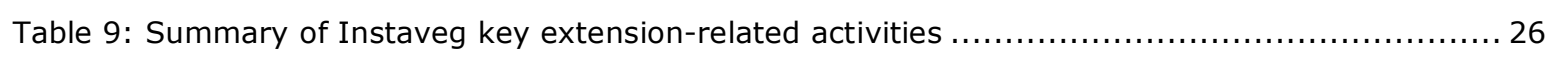

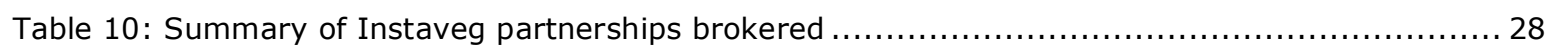

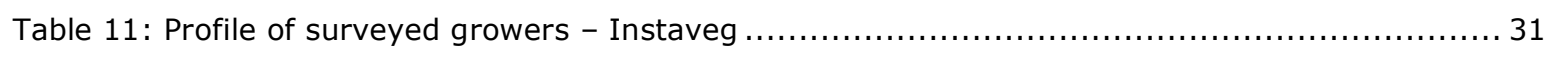

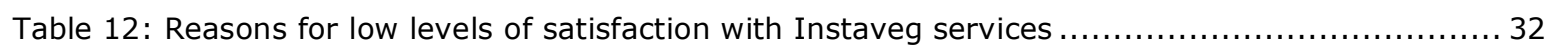

Table 13: Profile of the main commercial segment advisory products offered by PAL ..................... 36

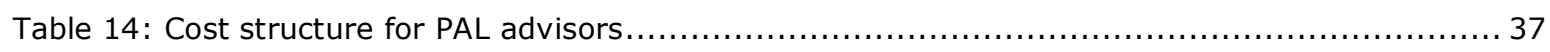

Table 15: Summary of main public and private partnerships established by PAL ....................... 38

Table 16: How assessment of PAL's advisory products has influenced service modifications ............40

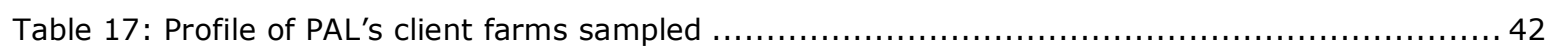

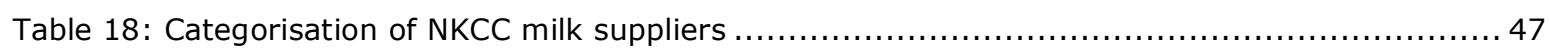

Table 19: NKCC service package, client targeting and business development aspects $\ldots \ldots \ldots \ldots \ldots \ldots 48$

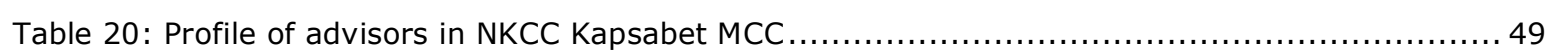

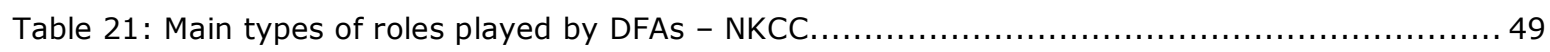

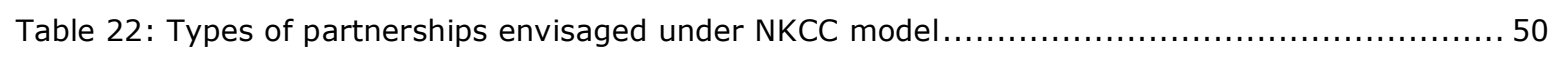

Table 23: Performance in milk intake by volume and number of suppliers - NKCC Kapsabet MCC.... 51

Table 24: Advisor costs vs. milk intake required to meet them - NKCC Kapsabet MCC................52

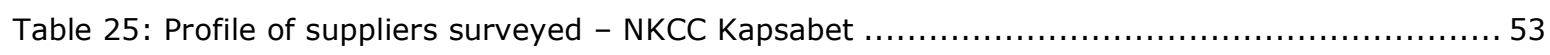

Table 26: Negative attributes about key providers of dairy advice - NKCC Kapsabet ................5 53

Table 27: Comparative analysis of design features and performance of the four models................58 


\section{Boxes}

Box 1. About the 3R Kenya project

\section{Figures}

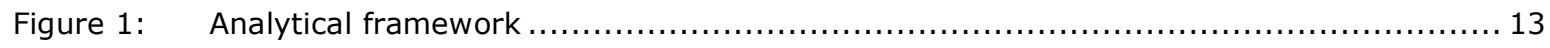

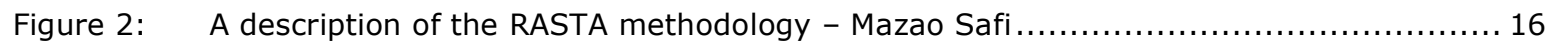

Figure 3: $\quad$ Farmers main sources of farming advice and information- Mazao Safi....................21

Figure 4: $\quad$ Farmers adoption of improved practices linked to MS support- Mazao Safi $\ldots \ldots \ldots \ldots \ldots 22$

Figure 5: $\quad$ Farmers constraints to adoption of improved practices - Mazao Safi $\ldots \ldots \ldots \ldots \ldots \ldots \ldots . \ldots . \ldots . \ldots 22$

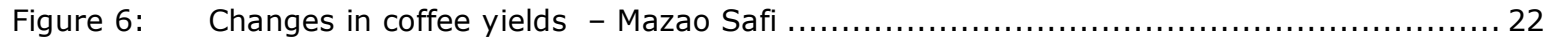

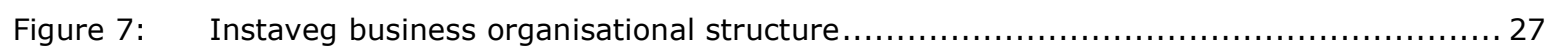

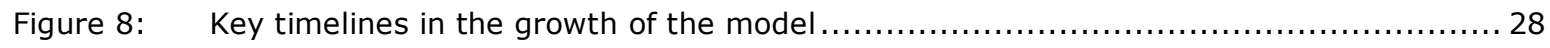

Figure 9: $\quad$ Main market outlets for leading commercial crops by percentage - Instaveg .............. 30

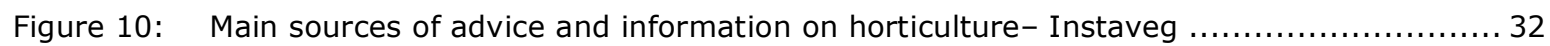

Figure 11: Farmers adoption of improved farm practices - Instaveg ............................. 33

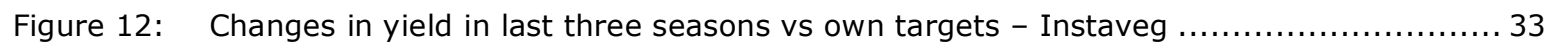

Figure 13: Trends in uptake of selected advisory service products per year - PAL $\ldots \ldots \ldots \ldots \ldots \ldots \ldots \ldots \ldots$

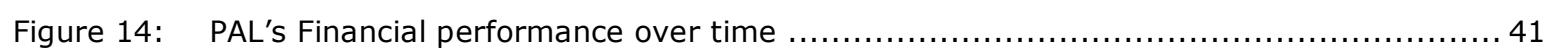

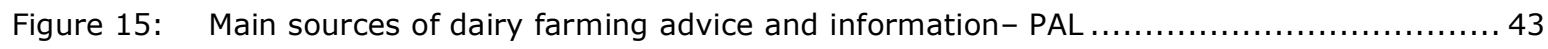

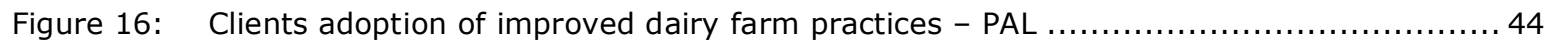

Figure 17: Types of investments made to improve the dairy farms - PAL $\quad$ T.......................44

Figure 18: Performance in average daily liters per cow vs. own targets - PAL ....................44

Figure 20: Performance on linkages with inputs and services by end of 2018- NKCC Kapsabet .....51

Figure 21: Farmers main sources of dairy advice and information- NKCC Kapsabet...............5 53

Figure 22: Percentage of suppliers adopting improved dairy practices - NKCC Kapsabet ...........54

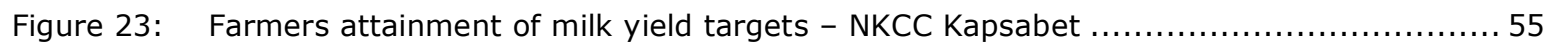




\section{Abbreviations and acronyms}

\begin{tabular}{|c|c|}
\hline AAK & Agrochemicals Association of Kenya \\
\hline ADI & Academy of Dairy Investors \\
\hline ADM & Academy of Dairy Managers \\
\hline AEAS & agricultural extension and advisory service \\
\hline AFA & Agriculture and Food Authority \\
\hline ATM & automated teller machine (milk-vending machine) \\
\hline COLEACP & Europe-Africa-Caribbean-Pacific Liaison Committee \\
\hline DFA & dairy farm assistants \\
\hline DFB & Dairy Farm Benchmarking \\
\hline DMP & Dairy Master Plan \\
\hline EA & Extension Agent \\
\hline EC & Extension Committee \\
\hline FIP & Farm Improvement Plan \\
\hline GAP & good agricultural practices \\
\hline $\mathrm{HCD}$ & Horticulture Crop Directorate \\
\hline IEC & Information, Education and Communication \\
\hline KEPHIS & Kenya Plant Health Inspectorate \\
\hline MCC & milk collection centres \\
\hline MRL & maximum residue limits \\
\hline MSF & medium-scale farms \\
\hline NGO & non-government organisation \\
\hline NKCC & New Kenya Cooperative Creameries \\
\hline OFC & On-Farm Coaching \\
\hline PCPB & Pests Control Products Board \\
\hline PCP & pest control product \\
\hline PES & private extension services \\
\hline QMS & quality management system \\
\hline RASTA & Register, Analyse, Sharing, Training, Adjust/Action \\
\hline SAP & Structural Adjustment Programme \\
\hline SNV & Netherlands Development Organisation \\
\hline SOPs & standard operating procedures \\
\hline TA & Technical Assistant (Extension Advisor) \\
\hline TMC & total monthly costs \\
\hline ToT & Trainers of Trainers \\
\hline TVET & Technical and Vocational Education and Training \\
\hline VP & value proposition \\
\hline $3 R$ & Robust, Reliable and Resilient agrifood sectors \\
\hline
\end{tabular}




\section{Acknowledgements}

This assessment was undertaken as part of the 3R Kenya project.

This research was conducted by the $3 R$ Kenya project, which is funded by the Embassy of the Kingdom of the Netherlands in Nairobi, Kenya, within the framework of the Agriculture and Food \& Nutrition Security programme.

The research was made possible through collaboration of the four case study partners: TradeCare Africa Ltd, Perfometer Agribusiness Ltd, New Kenya Cooperative Creameries Ltd and Instaveg. We are sincerely grateful to these partners for being involved and for the cooperation of their teams throughout the study. We would also like to thank the various stakeholders - including farmers, input providers and dairy cooperative representatives - for their cooperation in undertaking this study.

The $3 R$ Kenya project is funded by the Embassy of the Kingdom of the Netherlands in Nairobi, Kenya, within the framework of the Agriculture and Food \& Nutrition Security programme.

The authors 


\section{Executive summary}

The Kenyan agricultural extension and advisory services (AEAS) system has evolved over time. In the early 1990s it moved - as the structural adjustment programmes (SAPs) were implemented - from a public sector-dominated system to one that recognises plurality and diversity of actors, including those offering market-driven services. This rapid shift caused gaps in the financing and provision of AEAS as the government scaled down its roles and resources allocated to them (Muyanga \& Jayne, 2008). The shift also coincided with an intensified global debate on the effectiveness and impact of AEAS. In 2001 a New Agricultural Extension Policy was formulated that sought to address the negative effects of previous top-down modalities by introducing participatory and demand-driven approaches. In 2012 the policy was revised to focus on promoting modalities for an effective pluralistic system (GoK, 2012).

Within this context, market-driven private sector AEAS models have emerged to exploit the opportunities of the transforming Kenyan agrifood systems. These opportunities come from growing urbanisation, with shifting dietary patterns linked to increased demand for more nutritious and safe foods, coupled with concerns for sustainable production. Consequently, value chain actors who wish to remain competitive and meet the shifting demands must continually innovate, which means that production is becoming a knowledge-intensive and technologically dynamic occupation. Commercially oriented farmers must therefore seek out the requisite technical and managerial (innovation) support through AEAS. This is driving a market for private AEAS and complementary services (Kabasa et al., 2015; Kilelu et al., 2011). Emerging models include those that focus on training and extension services - primarily training centres - and independent and chain-embedded services. However, little is documented about these private AEAS models emerging in developing countries, including Kenya (Veldhuizen et al., 2018; Zhou, 2015).

In this context, the 3R Kenya project conducted a study on selected private sector-led AEAS models in the Kenyan agrifood sector. The study sought to understand design and operationalisation features of the models; their performance from both supply- and demand-side perspectives; and their financial sustainability, scalability and contribution to inclusiveness. Applying a multiple case study design, four models were assessed. They were selected based on their spread across different model types and agricultural subsectors - dairy and horticulture/industrial crops (see Table A). Data were collected between February and May 2019 in selected regions (see Table A) through key informant interviews $(n=22)$ and a household survey of farmer clients $(n=144)$. Where available, secondary data for the cases was analysed, including business reports and data.

Table A: Key characteristics of AEAS models studied and fieldwork regions

\begin{tabular}{llll}
\hline Selected model & Model characteristics & Subsector focus & Fieldwork regions \\
\hline Mazao Safi & $\begin{array}{l}\text { Independent (farm- } \\
\text { enterprise focus) }\end{array}$ & $\begin{array}{l}\text { Horticulture/industrial } \\
\text { crops (avocado, bananas } \\
\text { macadamia, coffee) }\end{array}$ & Embu \\
Instaveg & $\begin{array}{l}\text { Chain-embedded (farm } \\
\text { enterprise focus) }\end{array}$ & $\begin{array}{l}\text { Horticulture (export and } \\
\text { domestic) }\end{array}$ & Kirinyaga and Nyeri \\
Perfometer & $\begin{array}{l}\text { Independent (commodity } \\
\text { focus) }\end{array}$ & Dairy & Various regions across the \\
NKCC & $\begin{array}{l}\text { Chain-embedded } \\
\text { (commodity focus) }\end{array}$ & Dairy & $\begin{array}{l}\text { Kapsabet milk collection } \\
\text { centre catchment (Nandi) }\end{array}$ \\
\hline
\end{tabular}

Mazao Safi (MS) is a social enterprise established in 2017 to support small- and medium-scale commercial farmers to increase productivity, quality and access to markets. MS uses a farmenterprise/multiple commercial crops approach. The design uses continuous farm data registration, analysis and sharing with clients to support performance decisions and action (RASTA methodology). MS has adapted a hub-and-spoke delivery model, whereby a field hub - resourced with advisors, agriinput store and mini soil lab - is established in a region (subcounty) and through which services are deployed to subregions (wards and villages) as the spokes. By 2018, MS had registered 731 (37\% females) clients and deployed four field advisors (at a ratio of 1:150 farmers) in the Embu pilot hub. Clients pay a standard monthly fee, initially set at KES 150. 
Instaveg Limited, established in 2013, is a new entrant in the Kenyan horticultural export industry. Instaveg uses an outgrower business model in which AEAS are embedded. The firm's AEAS support growers to produce multiple fresh vegetables - French beans, baby corn, green soya, green peas and courgette - for export to Europe and recently for domestic markets. By 2018, 300 small- and mediumscale growers had been contracted individually or via groups from Kirinyaga and Nyeri counties. The role of Instaveg's production (extension) team of three members is to coordinate production to match end-market demand and to supervise and provide decision support to meet stringent standards for niche market segments. Extension costs are internalised in the core business.

Perfometer Agribusiness Limited (PAL) is an independent dairy advisory firm registered in 2013. The firm targets medium-scale dairy farms (MSF) as a potential niche market segment for private and independent advisory services. Its business development was incubated by SNV's Kenya Market-led Dairy Programme (KMDP). The value proposition of PAL is to improve professionalism and profitability of dairy farms. The model develops distinct but connected advisory products and tools that are benchmarked against content and approaches from advanced dairy knowledge systems (e.g. the Dutch). By 2018, with a core team of 12 Nairobi-based advisors, PAL had developed seven main advisory products and served 205 MSFs across 14 counties in Kenya. MSF clients pay per product, with prices ranging from KES 30,000 to KES 400,000.

New Kenya Cooperative Creameries (NKCC) Limited is a state corporation and is among the oldest and leading dairy processors in Kenya. NKCC sources raw milk from small-, medium- and largescale dairy farms that operate individually or in groups. In response to increased competition for consistent supply of high-quality raw milk in Kenya, NKCC embedded a dairy advisory services component in its milk procurement strategy in 2012/13. The model was rolled out in all 18 milk collection centres targeting about 54,000 farmers. It is financed by a voluntary levy of KES 50 cents per litre of milk delivered by suppliers who sign the long-term supplier contract package. The package provides for other incentives such as linkages for complementary services and premium milk prices.

\section{Highlight of key findings, conclusions and recommendations}

The assessment confirms that different models of private-sector driven AEAS models emerge in response to agrifood sectors transforming towards sustainable commercialisation. The diversity is seen in terms of design and operationalisation. Common features are that the models: target entrepreneurial farmers, have ambitious (low) advisor:farmer ratios, and deploy personalised and regular farm visits as dominant delivery methods for AEAS. These delivery features limit outreach and raise the cost of service provision. The models differ in how they facilitate access to complementary inputs and services, costing and value capture strategies, the range of commodities supported, profiles and roles of advisors, farmer targeting and decision support.

The assessment shows mixed results in terms of their performance: delivery/uptake of extension services, revenue generation/financing, and benefits of extension to the focal firms' core businesses and farmers. On advice uptake and implementation as well as the resultant outcomes, some models are limited by lack of clearly defined performance goals, while for others AEAS are internalised in the core businesses of the firms in a manner that makes it difficult to distinguish their costs and benefits. Efforts to leverage digital technologies to improve advisory services were yet to bear the envisioned benefits.

The costing of AEAS and the design of an accompanying financing model seem to be critical yet challenging areas. Even the independent services models, which have a clear costs and pricing structure, faced challenges relying on the commercial segment and have to explore other alternative sources of financing (mainly donor funding and private partnerships) to be able to recover full costs of AEAS delivery. This is an important issue to consider when moving forward, as financial sustainability is a key factor informing scalability. Regarding inclusiveness, we find that the models have a business policy of excluding farmers who do not meet set criteria. Also, they do not explicitly target women and youth as categories of farmers facing higher exclusion risks in access to AEAS. However, in some models, women and youth constitute over $30 \%$ and $15 \%$ of clients respectively. This suggests the need for more nuanced understanding of inclusion and exclusion.

Other broader observations are that the (re) design of the models seem not to rely much on robust analytics and diagnostics. Second, linkages to stable and gainful output markets is a key condition underpinning feasibility of the models. Third, there are broader challenges that require a proactive public sector primarily in policy and regulation, human resource development and co-financing mechanisms. Fourth, the findings vouch for structured rather than one-off financial and technical support from development partners. 


\section{Introduction}

\section{$1.1 \quad$ Background}

The Kenyan agricultural extension and advisory services (AEAS) system has been evolving over time. Overall, three main distinct phases have spanned three eras: colonial (early 1900s to 1963), postindependence (1964-1990s) and post-Structural Adjustment Programmes (SAPs) (since the early 1990s). The revised National Agricultural Sector Extension Policy of 2012 (GoK, 2012) is the most decisive step taken by the Kenyan government to provide policy direction in a pluralistic AEAS landscape. The policy articulates and recognises the shift from public sector domination - which characterised the colonial and post-independence eras - to a post-SAPs era of plurality and diversity of actors, in the financing and/or provision of AEAS.

The role of the private sector in delivering AEAS is of interest in relation to agrifood systems transformation in most developing countries such as Kenya. Transforming agrifood systems are linked to global economic and demographic trends of increasing population and urbanisation, a growing number of middle class consumers, changing dietary and consumption patterns and growing concern about quality and safety of food and how it was produced (Haggblade, 2011; McCullough, Pingali, \& Stamoulis, 2008). In Kenya, these trends present opportunities, challenges and risks not only to farmers but also to the array of value chain actors involved in food systems. Farmers face higher demand for nutritious foods that require increased productivity and fewer negative effects on environmental sustainability. This is linked to increasingly formalised market systems with high demand for consistent and reliable supply of food that is safe, of high quality and adheres to good agricultural practices (GAPs) during production and post-harvest handling (McCullough, Pingali, \& Stamoulis, 2008). Agrifood systems are therefore becoming increasingly knowledge-intensive and technologically dynamic as value chain actors who wish to remain competitive are compelled to continually innovate to address challenges and take up new opportunities (Kabasa et al., 2015; Kilelu et al., 2011; McCullough, Pingali, \& Stamoulis, 2008).

At the production level, producers who aspire to be part of this transformation must become more entrepreneurial and seek out the requisite technical and managerial support services for sustainable and competitive farming enterprises. For farm produce output aggregators and processors, it has become a compelling business case to invest in providing knowledge and technology support to their suppliers as part of developing and securing a reliable supply base for high-quality raw produce. This has put a spotlight on AEAS and on the growing role of private sector businesses in delivering AEAS and complementary services. These services, also referred to as innovation support services (Kilelu et al., 2011; Faure et al., 2018) seek to provide demand-driven, innovative market-based solutions to entrepreneurial farmers. Several private sector AEAS business models are emerging in this dynamic and transforming Kenyan agrifood system. These include those that focus on training and extension services - primarily training centres - and independent and chain-embedded models.

While these private providers are emerging and experimenting with new institutional and organisational arrangements to offer market-led AEAS, assessments on other AEAS models in Kenya have revealed mixed experiences. First, the public sector models have generally been perceived as ineffective and slow in coping with the dynamic demands of modern agriculture (Gautam \& Anderson, 1999; Zhou, 2015); or they have faced systemic inefficiencies in resource allocation and coordination in the wake of pluralism (Poulton \& Kanyinga, 2014). However, recent pilots on publicly fundedprivately provided partnerships have been found to be viable if farmer cooperatives are strengthened (Bebe et al., 2016). Second, private-sector provision effectively fills the public subsystem gaps, though their services are perceived to be skewed towards high-value agricultural enterprises. Third, the value of non-profit civil society AEAS models (NGOs and faith-based organisations) in reaching the poor, remote and subsistence-oriented producers is acknowledged, though outreach has been observed to be limited (Muyanga \& Jayne, 2008). Overall, the prominent role being taken up by private sector AEAS models in Kenya is increasingly recognised (DLEC, 2019; Zhou, 2015). However, little is documented about these private AEAS models emerging in developing countries, including Kenya (IDH, 2016; IFC, 2014; Veldhuizen et al., 2018; Zhou, 2015).

It is therefore timely to assess these models and draw lessons and insights from them. The 3R Kenya project conducted a study on selected private sector-led AEAS models in the Kenyan agrifood sector in 
2019. The study sought to understand the design and operationalisation features $f$ the AEAS models; their performance both as businesses and from the perspectives of the farmer clients; and their financial sustainability, scalability and contribution to inclusiveness.

The outline of the report is as follows: Chapter 1 presents the study background and methodology; Chapters 2-5 present the findings, conclusions and recommendations for each of the four AEAS model studies; and Chapter 6 provides a synthesis of the four models.

Box 1: About 3R Kenya Project

The 3R Kenya (Resilient, Robust, Reliable - from Aid to Trade) project is a learning initiative supported under the Agriculture and Food \& Nutrition Security (FNS) programme of the Embassy of the Kingdom of the Netherlands. 3R Kenya seeks to assess evidence and lessons from FNS and other related programmes that support competitive, market-led models in spurring agricultural development. It focuses on the aquaculture, dairy and horticulture sectors. 3R Kenya is executed at a time when the Dutch government's bilateral relations in Kenya are transitioning from a focus on Aid to Trade to enhance the development of agrifood sectors. Through evidence generation and stakeholder dialogue, 3R seeks to contribute to an understanding of effective conditions for sustainable inclusive trade for transforming resilient, robust and reliable agrifood sectors.

\subsection{Analytical framework}

In this assessment, "private sector models" refer to AEAS that are driven by for-profit firms or agribusinesses. We distinguish them from other non-public AEAS models - such as those driven by non-profit actors and producer organisations - that are often categorised as part of the broader private sector AEAS subsystem as noted in literature (Birner et al., 2009; Feder et al., 2011; Veldhuizen et al., 2018; DLEC, 2019). This literature analyses an AEAS model through its various design features and performance parameters, including the distinct organisational arrangements in private extension service delivery and the private and public modalities through which these services are financed. We then integrated these perspectives with business organisation literature that has advanced the thinking on business models innovation and offers other lens for understanding these emerging private sector AEAS models. The concept of business models describes how an organisation or firm creates, delivers and captures value through products and services they offer to specific customer segments to solve customers' particular problems (Osterwalder \& Pigneur, 2010; Rosca et al., 2016; Teece, 2010). The emphasis in this literatures is that a business creates and delivers value to customers (value creation) and has a related architecture of revenues, costs and profits associated with what it offers (value capture). The architecture also entails building partnerships or an innovation ecoystem of multiple actors that is a prerequisite for delivering the businesss value proposition (Talmar et al., 2018; Teece, 2010). A strong business model is one that creates balance between creation, delivery and capture of value. From these combined perspectives, we developed an analytical framework to apply to this study (Figure 1).

The key research questions of the study were:

1. What are the design features of the selected private sector AEAS models emerging in the Kenyan agrifood sector?

2. How are the models performing from the supply-side perspective?

3. How are the models performing from the demand-side perspective? 


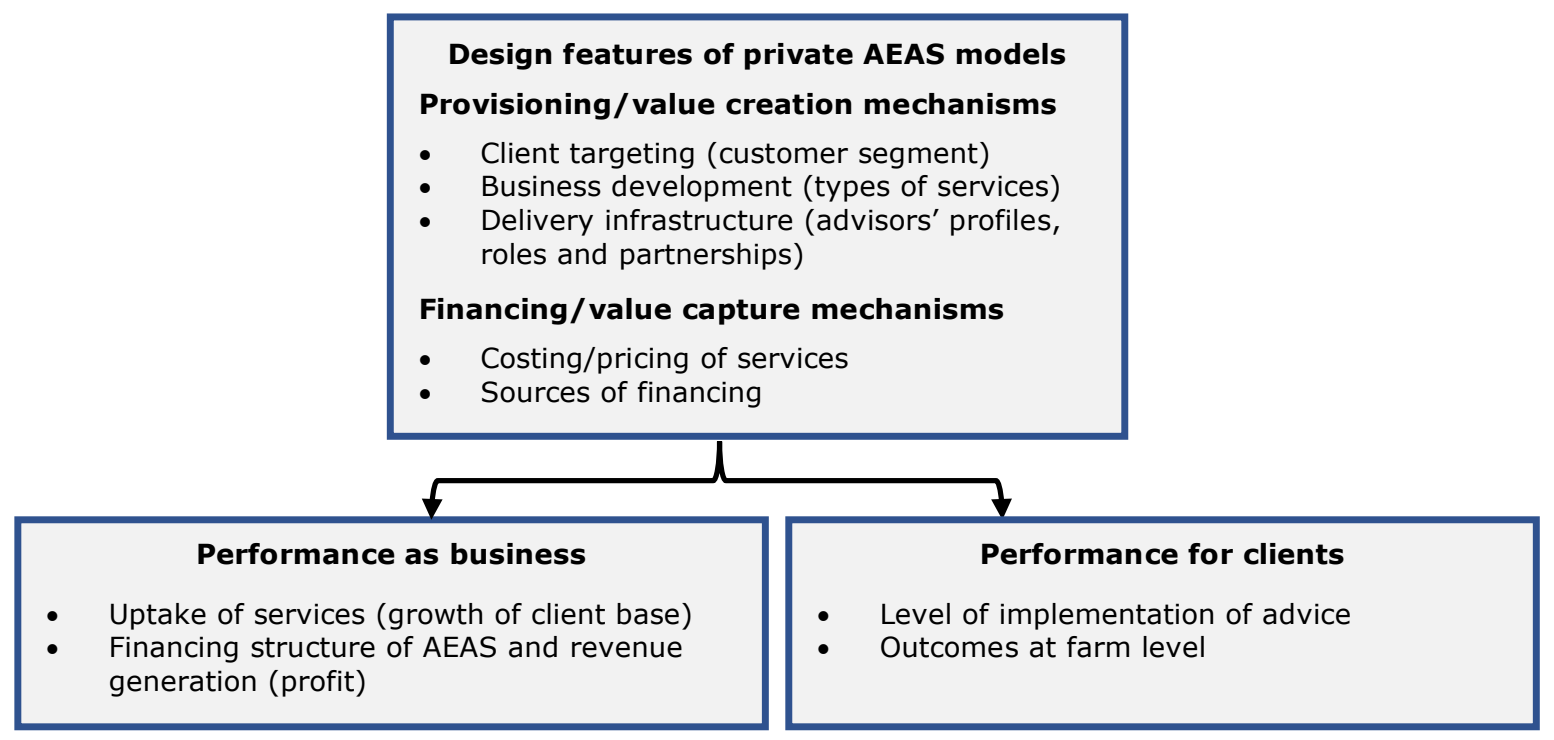

Figure 1: Analytical framework

Sources: Authors expounded from literature (Birner et al., 2009; Feder et al., 2011; Veldhuizen et al., 2018; Osterwalder \& Pigneur, 2010; Rosca et al., 2016; Teece, 2010)

\subsection{Methodology}

The research used a multiple case study design (Yin, 2009). Four cases were purposefully selected based on the innovative character of their business models, potential for scalability, and spread across types of models and agricultural subsectors - dairy and horticulture crops. These were two of the sectors of focus for the 3R Kenya project under which the study was undertaken.

To begin the study, a one-day seminar was organised in December 2018 with three of the selected case study partners to get preliminary insights about their models and discuss the study design. A fourth model, Instaveg, was identified later in consultation with other actors in the sector.

Various data of interest as outlined in the analytical framework were collected between February and May 2019 using mixed methods (see summary in Table 1). These included a survey of farmer clients, interviews with key informants and a documents review.

The key informant interviews with the business managers and staff collected data on design and operational features and performance of the business models. These data were complemented by secondary data, including business reports and information. For the survey of farmer clients, we aimed to sample $10 \%$ of all the farmers reached by the business cases. However, this was not achieved for one of the cases (Perfometer) due to the spread of clients across 14 counties. The farmers were surveyed about their socioeconomic characteristics, their sources of AEAS and their perspectives on what effect the AEAS of the linked business case had on farm-level outcomes: to what level the advice was implemented and how yield changed based on set targets. The data were collected manually because of initial challenges with programming of electronic devices. The data were then digitised by the enumerators using CSPro.

All interviews were recorded, transcribed, coded and analysed guided by the analytical framework. The survey data were analysed in STATA, focusing on descriptive statistics.

Table 1: Summary of case study partners and respondents

\begin{tabular}{|c|c|c|c|c|c|c|}
\hline \multirow{2}{*}{$\begin{array}{l}\text { Selected } \\
\text { case study }\end{array}$} & \multirow{2}{*}{$\begin{array}{l}\text { Business } \\
\text { model type }\end{array}$} & \multirow{2}{*}{$\begin{array}{l}\text { Subsector } \\
\text { of focus }\end{array}$} & \multirow{2}{*}{$\begin{array}{l}\text { Fieldwork } \\
\text { location }\end{array}$} & \multirow{2}{*}{$\begin{array}{l}\text { Key in- } \\
\text { formants }\end{array}$} & \multicolumn{2}{|c|}{ Farmers survey } \\
\hline & & & & & Sampled & Population \\
\hline Mazao Safi & Independent & Horticulture & Embu & 8 & 34 & 450 \\
\hline Instaveg & $\begin{array}{l}\text { Chain- } \\
\text { embedded }\end{array}$ & Horticulture & $\begin{array}{l}\text { Kirinyaga/ } \\
\text { Nyeri }\end{array}$ & 4 & 47 & 300 \\
\hline Perfometer & Independent & Dairy & 9 counties & 4 & 17 & 205 \\
\hline NKCC & $\begin{array}{l}\text { Chain- } \\
\text { embedded }\end{array}$ & Dairy & Nandi & 6 & 46 & 300 \\
\hline
\end{tabular}




\section{Case 1: Mazao Safi private extension services model}

\subsection{About the business}

Mazao Safi (which means 'safe harvest' in Swahili) (MS) is a division of TradeCare Africa, (https://www.tradecareafrica.com) a social enterprise founded in 2008. It uses knowledge from global value chains to invest in services that can support workers and smallholder farmers in Africa. Other divisions work on consultancy in sustainable trade, third-party certification (React Cert), market development for traceable and certified fresh fruit and vegetables for the domestic market (Soko Safi), and domestic safety and green technologies (Boma Safi). The founder-director is a social entrepreneur interested in finding market-based solutions to global poverty.

MS, a recent division that started operations in 2016 at Embu County, is the farmer extension arm of the company. Its aim is to deliver high-quality extension services in Kenya. The value proposition is "to promote access to extension services for small- and medium-scale farmers through a composite decision support system in order to increase productivity, quality and access to markets". The Embu hub is the pilot where the MS model is being trialled as an innovative arrangement for delivering private, independent extension services. TradeCare expects to use the lessons from the Embu hub to inform plans of scaling up.

\subsection{Design of Mazao Safi private extension services model}

The interview with the TradeCare founder and the review of some MS business documents (Mazao Safi, 2019) reveal how the MS extension model is premised on a farm enterprise, rather than a single value chain or commodity approach. As most (smallholder) farmers integrate multiple commodities/crops on their farms, both temporally and spatially, it makes sense to provide comprehensive support to the farmer across a mix of commodities/crops. At the time of assessment in the first hub in Embu County, Makengi subcounty, the model was focusing on offering advisory services to farmers of four perennial crops - coffee, banana, macadamia and avocado - and was considering expanding to seasonal crops (e.g. tomato).

MS uses a hub-and-spoke model, where a field hub is established in a targeted farming (rural) community. The hub has an agro-input store and a field office for the extension team. The team comprises a hub coordinator and technical assistants (TAs), and the TAs are dispatched from the hub to villages/zones within a radius of about 5-7 km (i.e. the spokes) to deliver services. This approach seeks to promote availability, accessibility, affordability and quality of agricultural inputs and services.

The private extension services (PES) are delivered through an elaborate methodology called RASTA (Mazao Safi, 2019) which, according to the founder, was developed through an international collaborative partnership with several organisations working to develop market-led service delivery models (Figure 2). RASTA is a data-driven approach to delivering individualised farm advice and implementation support. It uses five steps: Register, Analyse, Sharing, Training, and Adjust Action. This means that a TA begins engagement with a new farmer client by collecting baseline farm data and collaboratively setting targets related to improved yield, quality and income.

\subsubsection{Client targeting, business development, costing and financing}

The founder noted that MS targets specific types of farmers as potential clients, with the eligibility criteria being: i) minimum land (at least 1 acre) allocated to the commodities of interest, or a minimum number of trees - coffee (100 trees), macadamia, avocado or banana (50 trees); ii) ease of access to the farm by motorbike; iii) proof of access to labour and presence of key farm structures, including irrigation water; and iv) farmers' positive attitude to implementing advice. Using these criteria, MS had registered 731 clients in Embu by the time of the study ( $37 \%$ of whom were female). 
Extension services are part of a bundle of services and inputs offered by MS. Review of business documents and interviews found four distinct but interrelated inputs and service products (Table 2). MS was in the process of introducing produce aggregation and marketing as another product to its clients to provide broader value chain support. The intention was to charge a $10 \%$ commission on produce marketed. The founder also saw analytics of aggregated farm data as of potential business value as it can be leveraged to influence both public policy (e.g. county governments) and business partnerships (e.g. with coffee cooperatives and macadamia-processing companies).

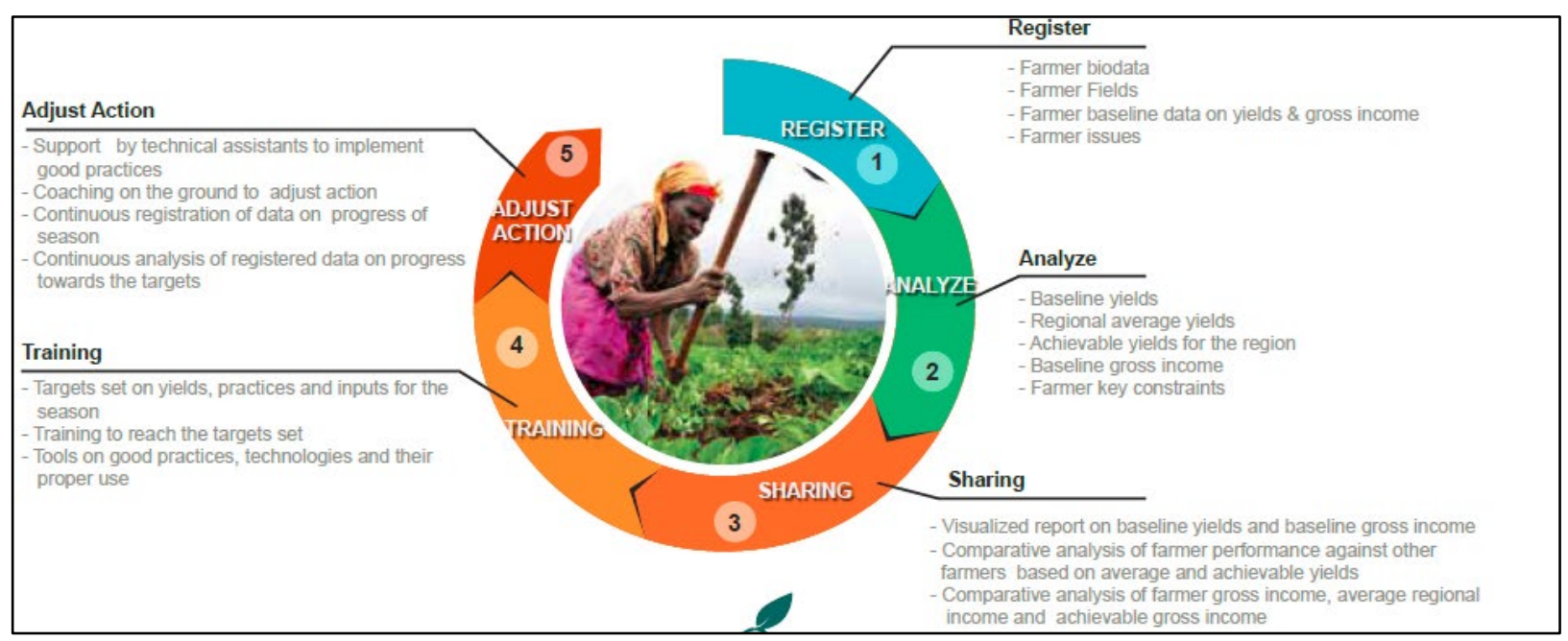

Figure 2: $\quad$ A description of the RASTA methodology

Source: Mazao Safi, 2019

Table 2: $\quad$ A profile of Mazao Safi's services package, costing and delivery approaches

\begin{tabular}{|c|c|c|}
\hline Product/service & Delivery and business development & Costing/pricing \\
\hline PES & $\begin{array}{l}\text { Each TA is assigned } 120-150 \text { farmers to offer } \\
\text { neutral and individualised extension support } \\
\text { through farm visits (twice per month). Farm data } \\
\text { is continuously collected and used to evaluate } \\
\text { uptake of advice and adjust where necessary } \\
\text { (RASTA approach; Figure } 1 \text { ). Farm visits are } \\
\text { supplemented by group training. Key support } \\
\text { tools include customised crop calendars and } \\
\text { enterprise reports. }\end{array}$ & $\begin{array}{l}\text { Clients pay a standard } \\
\text { monthly fee of KES } 300 \text {, but } \\
\text { this is initially discounted by } \\
100 \% \text { for the first six months } \\
\text { and then by } 50 \% \text { for a year } \\
\text { or so. }\end{array}$ \\
\hline $\begin{array}{l}\text { Soil testing and } \\
\text { amendment services }\end{array}$ & $\begin{array}{l}\text { The MS hub has a mini soil lab for rapid tests of } \\
\mathrm{pH} \text { and for the macronutrients nitrogen }(\mathrm{N}) \text {, } \\
\text { phosphorus }(\mathrm{P}) \text { and potassium }(\mathrm{K}) \text { to guide soil } \\
\text { improvement advice. All TAs are trained to collect } \\
\text { and test soil. Micronutrients are tested as an } \\
\text { additional service. }\end{array}$ & $\begin{array}{l}\text { Clients pay KES } 700-1,200 \\
\text { for macronutrient test. Clients } \\
\text { are advised to test soil after } \\
\text { every three years. }\end{array}$ \\
\hline $\begin{array}{l}\text { Curated farm inputs } \\
\text { services package }\end{array}$ & $\begin{array}{l}\text { MS shortlists (curates) recommended inputs } \\
\text { offered by different agro-input firms. The MS } \\
\text { input store sells some of these inputs, but clients } \\
\text { are at liberty to procure recommended inputs } \\
\text { elsewhere. MS store attendants embed advice in } \\
\text { the sale of inputs, including at farm delivery. MS } \\
\text { intends to gradually transition into organic } \\
\text { farming systems. }\end{array}$ & $\begin{array}{l}\text { Charges are based on inputs } \\
\text { purchased. MS generally } \\
\text { factors a } 10 \% \text { profit margin } \\
\text { onto the sale of inputs and } \\
\text { complementary services. }\end{array}$ \\
\hline Green technologies & $\begin{array}{l}\text { These technologies are accessible on credit to PES } \\
\text { clients, these include equipment, protective } \\
\text { clothing, solar lanterns and clean cookstoves. }\end{array}$ & $\begin{array}{l}\text { Charges are per technology } \\
\text { taken up. }\end{array}$ \\
\hline
\end{tabular}

Sources: MS secondary documents and interviews with director and advisors

\subsubsection{Advisors' profiles, roles and deployment}

Key informant interviews with the MS team provided an overview of the TAs' profiles and their roles. By the time of the study, the Embu hub had seven staff members (two females): the hub coordinator, four TAs, an input store assistant (akin to a TA), and a green technology assistant (Table 3). All were trained in agricultural courses at different levels. The TAs were aged 23-27. Their main role was to advise farmers on GAPs for the targeted crops. The TAs are backstopped by specialists (e.g. data analyst, senior agronomist) based in TradeCare's Nairobi office. 
The interviews suggest that technical/vocational (TVET)/diploma graduates had better fit for being TAs as they had a stronger practical orientation than their university peers.

The diploma training had a good balance between theory and practicals; we were involved in the school farm and at each stage (module) the exams included a component of a practical project in the farm ... and prepared us for field-based deployment. (Interview with a female TA)

Of course, my training (BSc. Agricultural Economics) did not prepare me well to play the technical roles of a TA; it was more of a managerial training, and I have had to catch up on my knowledge on crop science/agronomy. (Interview with a male TA, degree holder)

Initially we preferred experienced advisors with a background in out grower companies but realised they were not proactive and suitable. We experienced a high rate of attrition, then we changed tactic to scouting fresh graduates from local colleges through a three-month field attachment internship programme, upon which we offer employment to those who prove themselves.

(Interview with founder-director)

Advisors are kitted with a motorbike and a smartphone for communication and ease in data collection. They are also resourced with key standardised content messages, reference materials and guides. The TAs are expected to play other roles that include promoting other services offered by MS such as inputs and soil testing, delivering inputs, collecting soil samples for assigned clients, enforcing payments for extension services, and mobilising farmers for the planned produce aggregation and marketing product. TAs interviewed expressed tensions with some of these additional roles, especially considering that they were consequently incorporated in key performance metrics for TAs. The hub coordinator provides technical and administrative oversight and forging of partnerships with strategic actors. Continuous capacity development is provided for TAs through in-house orientation and induction, online courses (e.g. COLEACP ${ }^{1}$ ), and training and learning opportunities organised with experts from agrochemicals companies.

Table 3: $\quad$ Profile of technical advisors based at the Mazao Safi Embu field hub

\begin{tabular}{|c|c|c|c|}
\hline $\begin{array}{l}\text { Professional } \\
\text { qualification }\end{array}$ & Area of study & Training college & Age, gender, experience in MS \\
\hline $\begin{array}{l}\text { Diploma (3), } \\
\text { Degree (3), } \\
\text { Certificate } \\
\text { (1, the green } \\
\text { technology } \\
\text { assistant) }\end{array}$ & $\begin{array}{l}\text { The diplomas are } \\
\text { in General } \\
\text { Agriculture (3). } \\
\text { The degrees are in } \\
\text { Agricultural } \\
\text { Extension (1), and } \\
\text { Agricultural } \\
\text { Economics (2). }\end{array}$ & $\begin{array}{l}\text { Meru National } \\
\text { Polytechnic, National } \\
\text { Youth Service Yatta } \\
\text { School of Agriculture, } \\
\text { Rwika Technical } \\
\text { Institute, Moi } \\
\text { University, Chuka } \\
\text { University }\end{array}$ & $\begin{array}{l}\text { Age: } 23-29 \text { years } \\
2 \text { females, } 5 \text { males } \\
\text { The longest-serving TA had joined in } \\
\text { May } 2018 \text { (the pilot phase, so had not } \\
\text { served a crop season by the end of } \\
2018 \text { ). All are locals from Embu/Meru } \\
\text { willing to operate from the village hub. }\end{array}$ \\
\hline
\end{tabular}

Table 4: Key Mazao Safi partners

\begin{tabular}{ll} 
Partners by type & Areas of collaboration \\
\hline $\begin{array}{l}\text { Donor-funded programmes (e.g. IDH*, AFD*) } \\
\text { Research expertise from government agencies (CRI*, } \\
\text { KALRO*) }\end{array}$ & $\begin{array}{l}\text { Start-up support (financial and technical) } \\
\text { Content development and validation, capacity } \\
\text { development for advisors. }\end{array}$ \\
$\begin{array}{l}\text { Agro-chemical companies, commercial farms, } \\
\text { plantation management firms }\end{array}$ & $\begin{array}{l}\text { Content development and validation, input delivery, } \\
\text { capacity development for advisors. }\end{array}$ \\
Coffee cooperative societies & $\begin{array}{l}\text { Introduction to farmers, coordination for service } \\
\text { delivery and scaling. }\end{array}$ \\
Universities and TVETs* & Human resources (talent pool for TAs) \\
International agrifood businesses (COLEACP, & Capacity development, certification \\
GLOBALG.A.P) & \\
\hline IDH: The sustainable trade initiative; AFD: Africa Development Fund; CRI: Coffee Research Institute; KALRO: Kenya \\
Agricultural and Livestock Research Organization; TVET: Technical and Vocational Education and Training Institutes
\end{tabular}

\footnotetext{
${ }^{1}$ COLEACP is the Europe-Africa-Caribbean-Pacific Liaison Committee
} 


\subsubsection{Key partnerships and lessons learned in operationalising the model}

MS has diverse public and private sector actors as part of their business (innovation) ecosystem who contribute to the operationalisation of the business model's value proposition. The value addition of these actors includes content development and validation of extension resource materials and tools (e.g. crop calendars), capacity development for advisors, delivery of complementary inputs, and financial and other forms of technical support. Partners are both local and international, as well as both private and public (Table 4).

Though still at its formative stages, the model has generated some lessons. Interviews with advisors and field observations elicited some of these lessons, which can be related to the RASTA methodology (see Table 5).

Table 5: Key lessons learned on the design and operationalisation of the MS model

\begin{tabular}{|c|c|}
\hline $\begin{array}{l}\text { RASTA } \\
\text { element }\end{array}$ & Key lessons \\
\hline Register & $\begin{array}{l}\text { Based on interviews with the MS team: Identifying the farmers with more entrepreneurial } \\
\text { orientation and therefore with a positive attitude and willingness to implement advice on } \\
\text { improving farm outcomes is a critical process that should not be hurried. }\end{array}$ \\
\hline Analyse & $\begin{array}{l}\text { Based on interviews with the MS team: Farm-level data is a key element in designing and } \\
\text { delivering actionable and individualised advice and other services. As such, a well-thought-out }\end{array}$ \\
\hline Sharing & $\begin{array}{l}\text { data management and sharing strategy should be an integral part of the model at the design } \\
\text { stage. }\end{array}$ \\
\hline Training & $\begin{array}{l}\text { Based on field observations: The user-friendliness of enterprise calendars can be enhanced by } \\
\text { minimising technical jargon - active ingredients on information on pesticides and other } \\
\text { inorganic inputs; the calendars could be enlarged with high resolution pictures and graphic } \\
\text { elements; they could be laminated; they could incorporate elements of participatory enterprise } \\
\text { budgeting; they could include a guide to information that advisors need to collect in different } \\
\text { seasons; they could be revised periodically to reflect contextual experiences such as climate } \\
\text { change challenges. }\end{array}$ \\
\hline Adjust & Based on observations and interviews with the MS team: Experimenting with the most ideal \\
\hline Action & $\begin{array}{l}\text { advisor:farmer ratio and frequency of contacts requires closer monitoring since it has direct } \\
\text { effects on the model's effectiveness in service delivery and costing. }\end{array}$ \\
\hline
\end{tabular}

\subsection{Evaluating performance of the model from the supply- side (business model) perspective}

This section presents findings on the performance of the model from the supply-side perspective, where we examined i) uptake of AEAS and complementary services, and ii) financing and benefits of AEAS to the firm.

\subsubsection{Uptake of extension and other complementary services}

Interview data and document review provide insights about the uptake of extension and other related services, which are key performance indicators (KPIs) for MS. The model had registered 731 farmer clients ( $37 \%$ females) out of a target of 600 by the end of 2018 . However, only $82 \%$ were benefiting from extension services, as the TA team was short of one advisor. Each TA was expected to serve a maximum of 150 farmers. It was noted that expecting TAs to visit each farm client twice per month was difficult and likely to impair the quality of farmer-advisor interactions. Uptake of complementary services (e.g. soil testing and inputs) was noted to be below projections. According to three of the TAs interviewed, only 26 of the 450 farmer clients they were assigned had taken up soil testing services during the period May-December 2018. Yet under the model's projections, each TA was expected to broker on average 12 soil tests per month. The TAs attributed the low uptake to ambitious targets, limited appreciation about the value of farm-specific soil testing among farmers, and limited willingness to pay for a relatively new service.

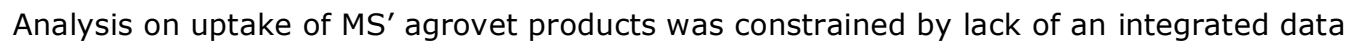
management system that could link extension clients and patronage of input store services and green technologies. 


\subsubsection{Financing AEAS and benefits of AEAS to the focal firm}

Profitable revenue generation is central to the MS business model. Each service product is offered on a commercial basis; that is, clients must pay for it. According to the founder-director, a TA costs on average KES 35,000 per month (salary and other operational costs); this means that a TA:farmer ratio of $1: 150$ with the current (introductory/discounted) monthly fee of KES 150 is insufficient even on cost-recovery basis, let alone profit-making. It was noted that farmers need to pay the full cost of KES 300 per month to allow for full cost recovery and a markup for the business. At the time of the study, we found that MS was not collecting the extension fees yet, although the first six-month free trial period had lapsed for most clients. From the survey, many farmers indicated willingness to start paying the KES 150 , but preferred this to be deducted from sales of their products.

Collection of the fees was a challenge noted by the TAs, and they felt that the role should be taken up by the hub coordinator while they focus on the technical issues. However, management did not agree with this position. Business strategy documents reviewed indicate that AEAS are expected to be a leading source of revenue for the business and its future growth (at $61 \%$ of MS's revenue annually), followed by soil analysis (20.4\%) and sale of inputs (14.7\%) between August 2019 and July 2020 (Table 6). These revenue projections are compared against a cost structure that has field hub staff as the most expensive resource, with $51.7 \%$ of total costs going to salaries and $15-34 \%$ to field operations (mobility, communication). Thus, for the model to be financially sustainable, an effective mechanism for collecting extension fees is imperative.

Overall, three observations can be made about this business model. First, costing and revenue generation strategies requires more attention to minimise chances of a false start. Second, MS has relied on its own capital and on donor support to set up the service delivery infrastructure and subsidise services in the start-up phase. Third, more effective value capture strategies are required to incentivise clients to remit AEAS fees.

Table 6: Revenue projections and interim performance experiences - Mazao Safi

\begin{tabular}{llll}
\hline $\begin{array}{l}\text { Revenue } \\
\text { streams }\end{array}$ & $\begin{array}{l}\text { Projected } \\
\text { contribution to } \\
\text { total revenue }\end{array}$ & $\begin{array}{l}\text { Targets for } \\
\mathbf{2 0 1 9}\end{array}$ & Performance experiences based on 2018 \\
\hline AEAS & $61.3 \%$ & $\begin{array}{l}50 \% \text { of clients } \\
\text { paying standard } \\
\text { monthly fee of } \\
\text { KES 150 }\end{array}$ & $\begin{array}{l}\text { Few clients had started paying after the lapse of six- } \\
\text { month initial free offer } \\
\text { Expectations that clients would pay cash upfront (as } \\
\text { the main value capture strategy for MS) was not } \\
\text { met }\end{array}$ \\
\hline Soil tests & $20.4 \%$ & $\begin{array}{l}\text { 12 soil tests per } \\
\text { TA per month }\end{array}$ & $\begin{array}{l}\text { Uptake was estimated at a total of 10 soil tests per } \\
\text { month in the run-up to 2019 (at KES 700- } \\
1,200 / \text { test) }\end{array}$ \\
\hline Input store & $14.8 \%$ & $\begin{array}{l}\text { Each TA to } \\
\text { broker inputs } \\
\text { worth } \\
\text { KES 300,000 per } \\
\text { month }\end{array}$ & $\begin{array}{l}\text { Average turnover was estimated at KES 10,000 } \\
\text { against the initial target of KES 20,000 per day } \\
\text { towards the end of 2018. The value capture strategy } \\
\text { is to retain a margin of 10\% }\end{array}$ \\
\hline Green technologies $3.7 \%$ & Not set & \\
\hline Sources: MS busing
\end{tabular}

Sources: MS business strategy documents (for data on revenue projections for eight upcoming hubs) and interviews with TAs, store attendant and hub coordinator (on targets and performance experiences).

\subsection{Evaluating performance of extension services from the demand-side perspective}

On the demand side we first analyse the profile of surveyed farmer clients, including their sources of farm advice and information, and reflect on the extent to which their characteristics match or do not with design features of the model - mainly client-targeting criteria and the value proposition (i.e. the relevance). We then evaluate how the farmers implemented the advice, and what changes in yield were seen on the farms. Generally, the limited period of engagement with farmer clients - average of nine months - did not allow for robust data that could be used to generate trends and patterns on these performance parameters. As such, the results should be interpreted as depicting preliminary performance of the model. 


\subsubsection{Characteristics of clients}

Thirty-four farmer clients were sampled, most of whom were male (56\%). The mean age was 55 years, with a minimum and maximum of 31 and 81 years (Table 7), which is consistent with findings from other studies (e.g. Minai et al., 2014; Ngeywo et al., 2015) in Kenya on the mean age of coffee farmers. A small number (03\%) were in the youth category.

The mean number of years in farming was 30 (coffee), 24 (macadamia) and 21 (dairy). This high mean age in farming perennial crops (coffee and macadamia) implies that most trees are likely to be aged and in need of rehabilitation or replacement. Most $(61.8 \%)$ clients have post-primary education (Table 7).

Table 7: $\quad$ Profile of farmer clients surveyed - Mazao Safi

\begin{tabular}{|c|c|c|c|}
\hline Class & Variable & Category & Per cent \\
\hline \multirow{10}{*}{$\begin{array}{l}\text { Profile of } \\
\text { respondents/clients }(n=34)\end{array}$} & Gender & Male & 55.9 \\
\hline & & Female & 44.1 \\
\hline & Age (years) & $\leq 35$ years & 2.9 \\
\hline & & $36-45$ years & 17.7 \\
\hline & & $46-60$ years & 41.2 \\
\hline & & $\geq 61$ years & 38.2 \\
\hline & Education level & No formal & 5.9 \\
\hline & & Primary & 32.4 \\
\hline & & Secondary & 47.1 \\
\hline & & Post-secondary & 14.7 \\
\hline \multirow{20}{*}{$\begin{array}{l}\text { Economic activities and } \\
\text { resources for clients' } \\
\text { households ( } n=34 \text { unless } \\
\text { otherwise indicated) }\end{array}$} & \multirow{3}{*}{$\begin{array}{l}\text { Percentage of farmers engaged in } \\
\text { main sources of income by } \\
\text { category. }\end{array}$} & On-farm & 100.0 \\
\hline & & Off-farm & 24.0 \\
\hline & & Remittances & 15.0 \\
\hline & Member of a farmer group & Yes & 100.0 \\
\hline & \multirow{3}{*}{$\begin{array}{l}\text { Percentage of clients engaged in } \\
\text { top three preferred commercial } \\
\text { commodities. }\end{array}$} & Coffee & 100.0 \\
\hline & & Macadamia & 88.2 \\
\hline & & Dairy & 52.9 \\
\hline & \multirow{4}{*}{$\begin{array}{l}\text { Accessible land by size (categories } \\
\text { informed by MS eligibility \& } \\
\text { targeting criteria) }\end{array}$} & $<1$ acre & 17.7 \\
\hline & & $1-1.5$ acres & 47.1 \\
\hline & & $<1.5-\leq 2$ acres & 8.8 \\
\hline & & $<2-6.5$ acres & 26.5 \\
\hline & \multirow{3}{*}{$\begin{array}{l}\text { Main land access rights } \\
\text { (multiple options apply for those } \\
\text { with more than one plot) }\end{array}$} & Inherited & 100.0 \\
\hline & & Purchased & 32.4 \\
\hline & & Leased & 8.8 \\
\hline & \multirow{3}{*}{$\begin{array}{l}\text { Scale of coffee plantation } \\
\text { (no. of trees). Categories informed } \\
\text { by MS eligibility \& targeting criteria } \\
(n=30)\end{array}$} & $100-200$ & 50.0 \\
\hline & & $201-500$ & 33.3 \\
\hline & & $501-900$ & 16.7 \\
\hline & \multirow{3}{*}{$\begin{array}{l}\text { Scale of macadamia plantation } \\
\text { (no. of trees). Categories informed } \\
\text { by MS eligibility \& targeting criteria }\end{array}$} & 0 & 20.6 \\
\hline & & $<50$ & 70.6 \\
\hline & & $50-100$ & 8.8 \\
\hline
\end{tabular}

Farming is the predominant economic activity undertaken by clients' households. The leading commercial commodities were coffee, macadamia and dairy. Avocado and banana were reported as alternative commodities gaining commercial orientation (Table 7). All households participated in a coffee cooperative. Further, clients have been exposed to international segments via local coffee cooperatives and processing companies and to national and local segments via local traders for macadamia and milk.

About $18 \%$ of clients have access to less than 1 acre of land, which is below the eligibility threshold for MS clients. The average accessible land is 1.8 acres, and the minimum and maximum were 0.25 and 6.5 acres respectively. Inheritance $(100 \%)$ is the dominant land access mechanism followed by purchase (32.4\%). Engagement with land rental market appears low, as only $8.8 \%$ had leased land for farming (Table 7). Overall, average accessible land per household is lower than the county level average, which is estimated at 2.7 acres (CGE, 2019).

Tree inventory data show that most clients either did not have $(20.6 \%)$ macadamia trees or operated at a scale below the 50 trees eligibility threshold (70.6\%) that MS has set for macadamia. All the surveyed clients who provided data on their coffee plantation meet the 100 trees threshold, and the majority (50\%) operate at a scale of 100-200 trees (Table 7). The average number of trees was 326 and 25 for coffee and macadamia respectively. The minimum and maximum were 110 and 900 trees 
(for coffee), and zero and 80 trees for macadamia trees (Table 7). A recent survey reports an average of 348 coffee trees per farmer in neighbouring Kirinyaga county (Minai et al., 2014).

\subsubsection{Main sources of farming advice and information}

According to the survey data (Figure 3), MS is cited as the leading source of information and advice about farming. Besides MS, other providers are cooperatives (mainly for coffee), agro-inputs suppliers, peers, produce buyers, county government, media and NGOs. Overall, the provider landscape indicates a plurality of providers dominated by private sector players. Most respondents $(95 \%)$ report access to farming advice to have been predominantly free. However, given the dominance of private sector players, it is likely that farmers perceive advice or information embedded in the purchase of produce or sale of inputs as free. Further, when asked what they dislike about their main sources of advice, most sentiments (see table 8 ) were related to services offered by MS, cooperatives and the county government. Use of mobile phones to access advice and information was reported to be low, mainly due to low access to smart phones and/or limited proficiency.

\begin{tabular}{|c|c|c|}
\hline Mazao Safi & 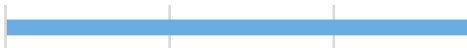 & 100 \\
\hline Cooperatives & \begin{tabular}{l|l|l} 
& $=$ \\
\end{tabular} & \\
\hline Inputs suppliers & 35 & \\
\hline Peers & \begin{tabular}{|l|l} 
& 29
\end{tabular} & \\
\hline Buyers-Processors/traders & 21 & \\
\hline County Government & 15 & \\
\hline Media-Radio/TV & 12 & \\
\hline NGOs & 9 & \\
\hline \multicolumn{3}{|c|}{ \% of respondent } \\
\hline
\end{tabular}

Figure 3: Farmers main sources of farming advice and information- Mazao Safi $(n=34)$

Table 8: $\quad$ Negative attributes about main sources of farming advice and information - Mazao Safi

\begin{tabular}{ll} 
Cooperatives and county government & Mazao Safi \\
\hline Irregularity or no longer available & Cost of implementing recommended actions \\
Weak on follow-up & Lack of credit plan for recommended inputs \\
Weak in linking advice to inputs access & Labour demand of recommended actions \\
Poor in practical orientation, new ideas & Unreliability of TAs to attend to hotline calls \\
\hline
\end{tabular}

On average, respondents had been clients of MS for nine months, with a minimum and maximum of five and 25 months respectively by January 2019. Most respondents ( $82.4 \%$ ) had been clients for less than 12 months. Considering the long cycle of perennial crops (especially in rehabilitating hitherto neglected trees, as was reported to be the case), most clients had short experience with the MS AEAS. Most respondents came to know of MS services via farm visits by MS TAs (68\%), then through their peers $(20 \%)$. The majority $(40.7 \%)$ cite the prospects of accessing extension services in general as the main reason for signing up (given that public extension officers have disappeared). Other reasons relate to the focus on increasing yields, personalised/individualised approach, practical advice based on farm visits, the focus on coffee, and regular follow-ups. All clients recall signing an agreement with MS about the provision of AEAS. However, about a quarter $(26.5 \%)$ could not recall the terms in detail. The majority (56\%) of respondents identified additional services they would like MS to consider in their service package, such as inputs on credit, crop-based advances, advice on additional farm commodities (e.g. dairy) and facilitation of produce marketing services.

\subsubsection{Implementation of advice}

All survey respondents reported to have made some improvements in their farm planning and management practices since partnering with MS, as summarised in Figure 4. Most of these practices require application of external inputs, mainly to improve nutrition and control pests and diseases. The main constraints to adoption of GAPs are limitations in financing and effects of erratic weather 
patterns (Figure 5). Farm operations cited as labour-intensive for coffee are harvesting, spraying, weeding, pruning and desuckering, fertilisation and manuring. Hiring casual seasonal labour is common practice but getting labour was a constraint for some farmers. Booking early and retaining a regular workforce was cited as a key strategy to ensure availability.

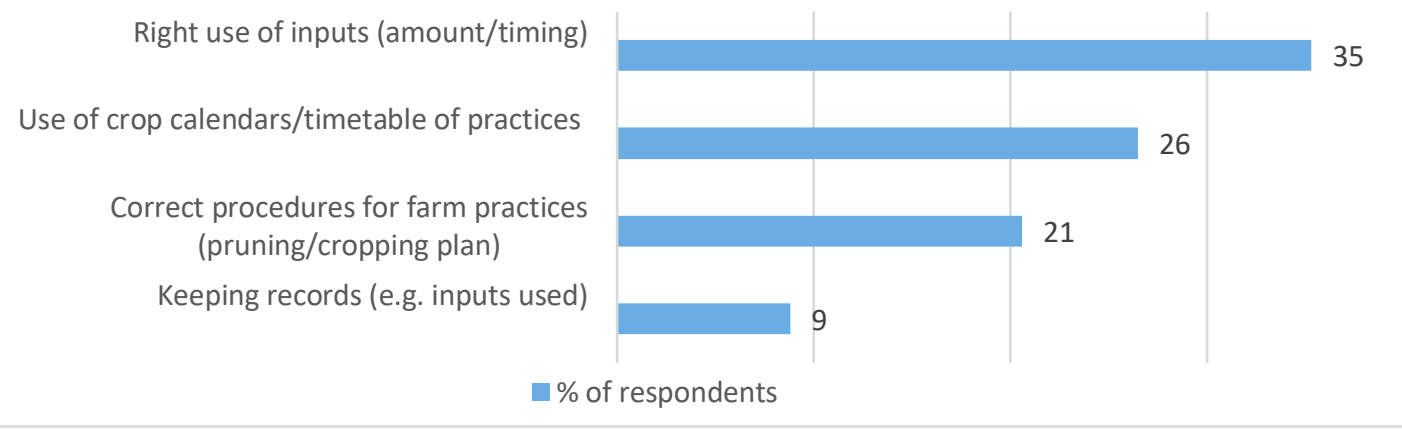

Figure 4: Farmers adoption of improved practices linked to MS support-Mazao Safi $(n=34)$

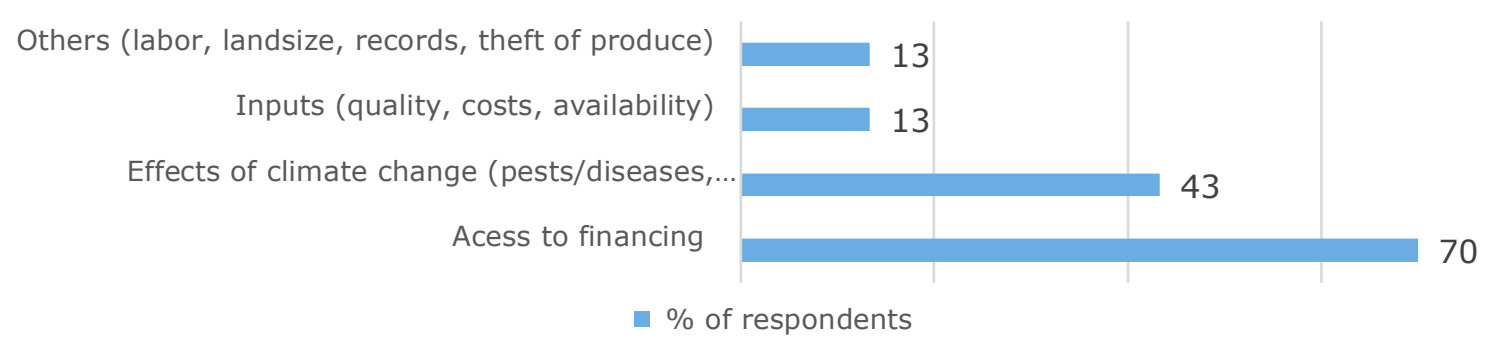

Figure 5: $\quad$ Farmers constraints to adoption of improved practices - Mazao Safi $(n=30)$

\subsubsection{Changes in coffee yield}

Most respondents registered for MS AEAS midway through the coffee crop season for 2018. It was therefore too early to evaluate changes in farm-level outcomes at the time of this assessment. Based on baseline survey data from the 2017 season $(n=555)$, MS recommended clients to target an average yield for coffee (cherries) of $10 \mathrm{kgs}$ per tree. Based on the average of $4 \mathrm{kgs}$ per tree reported at baseline (Boma Safi, 2019) this target requires a two-and half times increase in productivity per tree. However, the number of seasons required to achieve this medium-term target were not made explicit to clients. Survey data for this assessment $(n=31)$ shows that most respondents did not achieve the $10 \mathrm{kgs} /$ tree target for the 2018 crop season. The average yield per tree for 2018 season was estimated at $4 \mathrm{kgs}$, indicating no improvement relative to 2017 season as per MS baseline data. The lowest and highest yields per tree reported in the 2018 season survey are one and fourteen respectively (Figure 6). However, these average yields are higher compared to those reported in other studies. For example, Minai et al. (2014) and Ngeywo et al. (2015) report average yields of $2.3 \mathrm{~kg}$ and $1.8 \mathrm{~kg}$ per tree in Kirinyaga and Kisii counties respectively, against a optimal yield of 10 kilos. MS TAs and clients interviewed attributed the below expectation yield performance partially to the severe coffee berry disease outbreak experienced in the 2018 season. Payment for the 2018 crop had not been declared by time of this assessment.

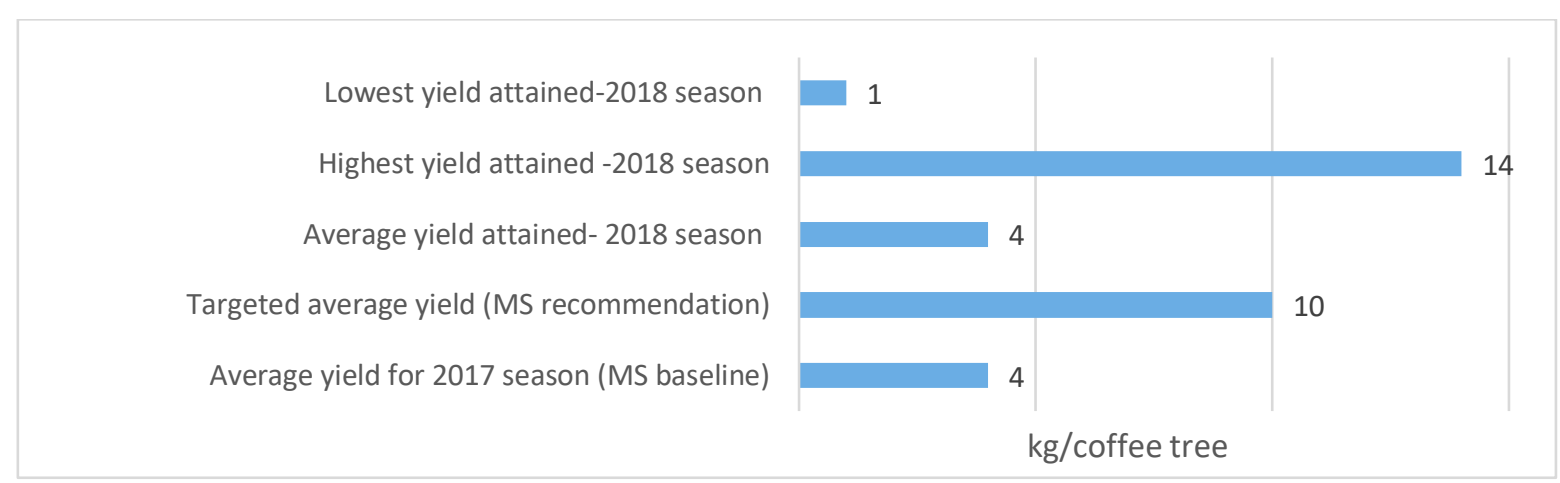

Figure 6: $\quad$ Changes in coffee yields - Mazao Safi 


\subsection{Conclusions and recommendations on MS model}

In this section we refer to the key questions guiding this assessment to draw conclusions and make recommendations.

\subsubsection{Design features and operationalisation of the model}

The value proposition of the MS business model is well articulated; it aims to improve yields, quality and farm profitability. The farm enterprise approach recognises the mixed farming system embraced by targeted farmer clients. Leveraging on the RASTA methodology, MS has configured an innovative model for delivering PES to commercially oriented small- and medium-scale farmers pursuing a diversified farming system. The model has continued to be tweaked even after the pilot phase, perhaps as part of a learning-by-doing approach.

Attention areas identified are:

i. Review key delivery and financing parameters - advisor:client ratio, frequency of contacts and delivery methods (perhaps monthly visits supplemented with non-farm-based methods e.g. digital AEAS approaches); extension user fees should cover costs and add to business revenue; finding an effective payment recovery mechanism is necessary.

ii. Tighten the client recruitment process to attract those with the most entrepreneurial mindsets; explore possibilities of segmenting clients further for targeted service products.

iii. Design a robust farm data management and sharing strategy and system to fully implement the RASTA methodology in enabling decision support of clients; explore the potential of the data collected for the larger business proposition of MS and TradeCare Africa broadly.

iv. Revisit business KPIs to rationalise between over-ambitious targets and most realistic optimal targets on the one hand and a gradual versus radical improvement pathway on the other.

v. Rethink advisor profiles, given that the business model expects advisors to play broader and more entrepreneurial roles besides the technical functions of facilitating farm advice.

\subsubsection{Relevance and effectiveness of extension services to clients}

The value proposition resonates well with targeted farmer clients, since improving farm yields remains a major pathway for improving their economic benefits given the gap between current versus optimal yields. However, the ability of the model to deliver extension services effectively is threatened by financial challenges encountered in its start-up phase. Low uptake of complementary services and recovery of extension services user fees are at the core of these financing challenges and allude to an underlying risk averseness even for entrepreneurial clients targeted. Also, the model had not yet rolled out services aimed at addressing two other key elements of the value proposition (improving quality and farm profitability). Regarding other elements of effectiveness, it is too early to evaluate the effects of AEAS to clients and their farms due to the short period of engagement. However, MS is identified as the most relied-upon source of advice and information by the farmers surveyed, and implementation of advice is rated high both in the survey and in MS's routine monitoring data.

Key attention areas observed are the need to:

i. demonstrate the value of the farm enterprise approach for commodity focused AEAS

ii. address the other two elements of the value proposition (improving quality and farm profitability as well as consider the other services gaps highlighted in the client survey findings (section 2.4.2).

\subsubsection{Inclusiveness, financial sustainability and scalability}

We observe that the model targets commercial small-scale farmers of varying characteristics in terms of farming resources endowment (land size and number of trees) and envisions further segmentation of clients. While the model does not explicitly target youth and women as clients, data suggests a relatively higher proportion of female clients (37\%). Data to determine composition of clients by age was not readily available, while the survey data (as proxy) suggests low outreach, as only $3 \%$ of respondents was in the youth category. 
The financial sustainability of the model depends on its ability to generate profit from AEAS as the leading revenue stream supplemented by other services (soil tests, inputs and commission from produce aggregation and marketing). Despite the limited implementation period at the time of assessment, findings suggest that an underlying risk averseness among clients to pay cash for AEAS services and to use complementary services poses a risk to the financial sustainability of the model.

It is premature to judge the scaling potential of the model. However, it was noted that TradeCare was implementing an ambitious plan of scaling the model in seven more hubs across Kenya, despite the limited period of testing and mixed results in the Embu pilot hub. 


\section{Instaveg outgrower extension services model}

\subsection{About the business}

Instaveg Limited is a new entrant in the successful Kenyan horticultural export industry (http://Instaveg.co.ke/about/about). The firm was established in 2013 to export fresh vegetables to the European markets, with the founder building on his previous experience working with horticultural export firms in Kenya. Instaveg is medium-scale enterprise that at peak season employs an average of 18 regular and 25 casual workers. The firm sources fresh vegetables - French beans, baby corn, green soya, green peas, and courgette - from an estimated 300 small- and medium-scale growers contracted in Mount Kenya region (Kirinyaga and Nyeri counties). The firm has leased the Horticulture Export Directorate's (HCD) pack house and offices in Mwea, Kirinyaga County for its operations. The business considers 720 tons in annual sales volume to be the break-even point.

\subsection{Design of Instaveg's outgrower embedded extension model}

Interviews with the founder-director and two managers (production and technical operations) provided details of the design features and operationalisation of extension services. The business model is characterised as an outgrower production model in which extension services are embedded, where the outgrowers are contracted and supported to produce and supply a variety of fresh produce. Prior to acquiring a direct export licence in 2019, Instaveg initially relied on intermediaries to access export markets. In addition, the firm has ventured into the domestic market for fresh fruit and vegetables.

According to the founder-director, the outgrower business relies on four critical success factors: scheduling production to match seasonal patterns of market demand, coordinating produce handling and marketing logistics, developing and sustaining loyalty from farmer suppliers, and assuring that produce meets the food safety and quality standards for destined markets. Consequently, the value proposition for Instaveg's AEAS can thus be summarised as to recruit growers and support them with knowledge on GAPs, coordinate production to match demand in targeted markets, to provide decision support, and supervise growers to meet stringent standards for niche market segments - currently export markets in the United Kingdom.

\subsubsection{Client targeting, business development, costing and financing}

Two types of growers are contracted to supply fresh produce: group-based and individuals. Groups comprise 15-20 members whose farms should be concentrated within a radius of $3 \mathrm{~km}$. Individual growers should be able to commit at least 2 acres of land to the contracted crops. The criteria for selection as outgrowers include the land-use history (in terms of previous crops) and suitability for intended crops, access to suitable water for irrigation, passable access roads to farms, proof of access to other resources such as labour, and farmers' interest in participating.

Instaveg enters into contractual arrangements with recruited outgrowers typically on a one-year, renewable agreement outlining:

i. the recommended GAPs that outgrowers must adhere to

ii. indicative produce buying prices, payment conditions, and other services to expect from Instaveg

iii. specifications on quality standards expected and production programme allocated

iv. sanctions for failure to adhere to GAPs

v. application procedures for pesticides and chemicals as advised by Instaveg advisors

vi. growers' agreement to not side-sell produce through other outlets. 
As part of the outgrower model, inputs and extension services delivery are embedded in the business. Thus, Instaveg supports outgrowers to access key agro-inputs and services as summarised below:

i. Providing seeds: first-time growers are supplied on cash terms; repeat growers on credit.

ii. Advising about fertiliser: the model advises growers on recommended fertilisers to use

iii. Supplying pest control products (PCPs): the model initially recommended products, but now supplies from a centralised in-house store and retains a contracted team of sprayers. These changes were in response to incidents of produce being rejected for exceeding maximum residue limits (MRL)

iv. Providing a planting programme and training in GAPs and compliance

v. Supporting growers to establish and maintain grading and aggregation centres

vi. Undertaking scheduled and random monitoring and advisory visits

vii. Providing a hotline for growers to communicate with production advisors

viii. Facilitating linkages with financial service providers where growers' payments are channelled; includes considerations for advance payments on a case-by-case basis.

Under the group-based contracts, group leaders monitor and support peers' farms to ensure compliance, taking on Training of Trainers (ToT) roles with backstop support from Instaveg advisors. Contracts with growers are counter-signed by HCD - a state agency mandated to coordinate production and marketing of horticultural crops in Kenya - as a witness, regulator and first call for arbitration.

Growers are charged for the inputs supplied via Instaveg' stores, with the costs deducted from the produce delivered. Extension-related services (see summary in Table 9) are an integral part of the business model, but from the interview with the director we noted that there has not been distinct analysis of their actual costs and value addition. Costs for the services are absorbed by the margin that the business retains between the sale of produce and payments to producers. Extension costs include overheads, such as personnel, and operational costs, such as training, transport and communication. The salary for a production advisor was estimated at KES 20,000-25,000 (gross) per month. While extension is not seen as a revenue generation stream in such an embedded model, the return on investing in AEAS to the core business of the firm needs to be clearly analysed.

Table 9: $\quad$ Summary of Instaveg key extension-related activities

\begin{tabular}{|c|c|c|}
\hline $\begin{array}{l}\text { Land-use } \\
\text { history } \\
\text { assessment }\end{array}$ & $\begin{array}{l}\text { The first visit to prospective growers' farms to assess } \\
\text { suitability: land-use history, road accessibility, water, etc. }\end{array}$ & $\begin{array}{l}\text { Instaveg production } \\
\text { team (agronomists) }\end{array}$ \\
\hline $\begin{array}{l}\text { First group } \\
\text { meeting }\end{array}$ & $\begin{array}{l}\text { Second visit for group-based growers to share information } \\
\text { about rules of engagement, verify the group's authenticity } \\
\text { and confirm consent to contract. }\end{array}$ & $\begin{array}{l}\text { Production team and } \\
\text { other colleagues (e.g. } \\
\text { quality assurance) }\end{array}$ \\
\hline $\begin{array}{l}\text { Planting } \\
\text { programme } \\
\text { meeting }\end{array}$ & $\begin{array}{l}\text { Meeting to share planting programme, train new growers in } \\
\text { key practices (land preparation, spacing, timings), supply } \\
\text { seeds. }\end{array}$ & Mainly production team \\
\hline $\begin{array}{l}\text { Training in } \\
\text { GAPs }\end{array}$ & $\begin{array}{l}\text { Held in central locations, pooling selected growers from } \\
\text { different areas and groups. Main topics: planting hygiene, } \\
\text { safe use of pesticides, crop nutrition, labelling for traceabi- } \\
\text { lity, harvesting hygiene and managing delivery of produce. }\end{array}$ & $\begin{array}{l}\text { Instaveg production } \\
\text { team, and other invited } \\
\text { experts from public and } \\
\text { private actors }\end{array}$ \\
\hline $\begin{array}{l}\text { Scouting/farm } \\
\text { monitoring } \\
\text { visits }\end{array}$ & $\begin{array}{l}\text { Random visits to monitor crop performance, check for pests } \\
\text { and diseases, check compliance (and recommend sanctions } \\
\text { in the case of non-compliance) and advise growers about } \\
\text { actions required, especially on spraying, weeding and } \\
\text { watering. }\end{array}$ & $\begin{array}{l}\text { Production and quality } \\
\text { teams, complemented } \\
\text { by group leaders } \\
\text { (ToTs) }\end{array}$ \\
\hline $\begin{array}{l}\text { Hotline calls- } \\
\text { based contacts }\end{array}$ & $\begin{array}{l}\text { Responding to emergency calls from individual growers } \\
\text { and/or group leaders to attend to observed concerns. The } \\
\text { calls can prompt an unscheduled farm visit and/or an off-site } \\
\text { decision such as sending sprayers or approving harvesting. }\end{array}$ & $\begin{array}{l}\text { Production team, but } \\
\text { often need to liaise } \\
\text { with technical and } \\
\text { quality departments, } \\
\text { depending on issue }\end{array}$ \\
\hline
\end{tabular}




\subsubsection{Advisors' profiles, roles and deployment}

Instaveg comprises five departments (Figure 7). The production team has three agronomists, including the unit manager; this department works the most in extension services (Figure 7). Production advisors have certificates and/or diplomas in general agriculture or related fields, and prior experience in an outgrower firm or agrochemical company is preferred. Agronomists are also employed in areas such as technical operations and quality assurance. Most roles in other departments require secondary education and on-the-job training.

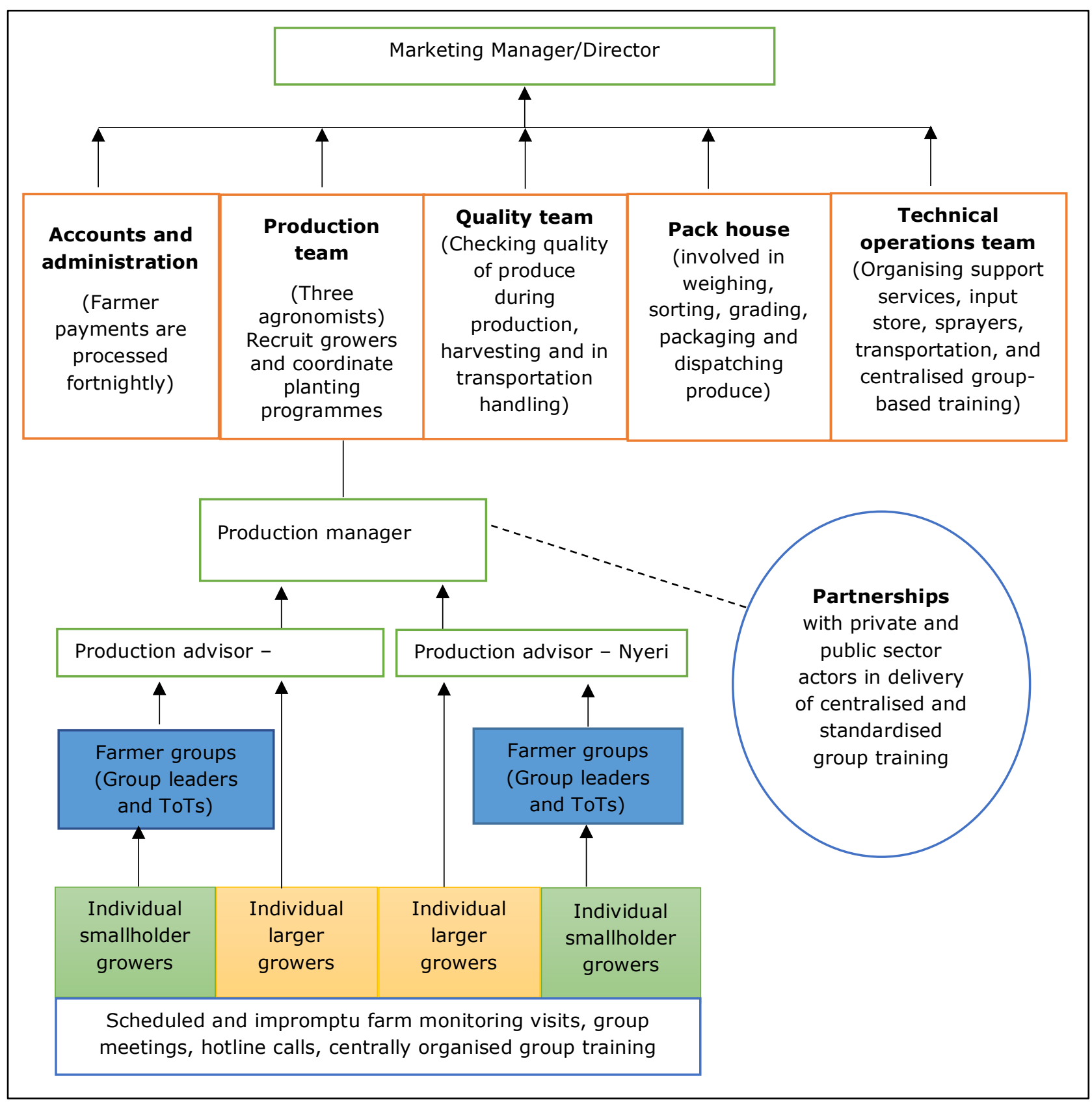

Figure 7: $\quad$ Instaveg business organisational structure

Production team members are each supplied with a motor bike and a post-paid phone to ease communication with growers. They are expected to visit three contractors per day or each contractor at least once per week during growing seasons (a group supplier is considered as a single contractor). There is no benchmark on production advisor:grower/contractor ratio as it depends on grower density and ease of mobility. The Nyeri advisor was coordinating 35 active contractors during the season coinciding with this assessment (note farmers in one group are considered as a single contractor/entity). He estimated that he was covering on average $40 \mathrm{~km}$ per day.

Ideally, every member of staff who has direct contact with the farmers is like an extension advisor ... be it in accounts, quality, pack house or technical operations. However, we are supposed to have three active agronomists serving as production advisors, but we laid off one recently. Each of these production advisors is supposed to visit three entities/suppliers (group is 
treated as one entity/supplier) per day during a growing season, therefore 18 farm visits per week, and file a weekly report on each entity. However, we have not been following these procedures keenly. (Interview with founder-director)

Advisors are also expected to hold weekly meetings and training sessions. They are further supported by colleagues from other departments such as accounts, which calculates growers' deductions and pay-outs; the quality assurance team, which grades produce; and the technical operations team, which manages the stores for PCPs, organises centralised training and schedules sprayers. Demand for advice can be intensified by weather conditions and outbreaks of pests and diseases. Advisors work closely with local public extension officers and suppliers of PCPs, especially to monitor pest and disease outbreaks. Good production advisors meet fresh produce supply targets, address growers' seasonal problems, maintain good relations with growers, and above all are firm on malpractices.

Table 10: Summary of Instaveg partnerships

\begin{tabular}{lll}
\hline Nature & Examples & Main roles \\
\hline Public & PCPB* & Training in safe use of pesticides, regulatory services \\
& Social services & Capacity-building and regulation of farmer groups \\
& HCD/AFA* & Regulatory and licensing services, lease of pack house facility \\
& KEPHIS* & Testing on MRLs \\
& Local hospitals & Training growers in first aid and hygiene \\
\hline Private & Agrochemical companies & Training in agrochemicals and integrated pest management \\
& Food processors & Expertise on food safety and technology \\
& ReAct Africa & Audit and certification services for GLOBALG.P. \\
\hline Industry & AAK* & Coordinating training offered by members (agrochemical \\
associations & & companies) \\
& COLEACP* & Financial support for certification services \\
\hline Non-profit & SNV/HortImpact & Staff and farmer training; co-financing renovation of collection and \\
& programme & grading infrastructure to attain GLOBALG.A.P certification \\
\hline
\end{tabular}

* PCPB: Pests Control Product Board; AFA; Agriculture and Food Authority; KEPHIS: Kenya Plant Health Inspectorate; AAK: Association of Agrochemical Companies in Kenya; COLEACP: Europe-Africa-Caribbean-Pacific Liaison Committee

\begin{tabular}{|c|c|c|c|}
\hline & $\begin{array}{l}\text { 2016-17: More } \\
\text { controls on PCPs }\end{array}$ & & $\begin{array}{c}\text { 2019: Acquires GLOBAL } \\
\text { GAP certification }\end{array}$ \\
\hline $\begin{array}{l}\text { out the business } \\
\text { targeting } \\
\text { outgrowers from } \\
\text { Kirinyaga and } \\
\text { Nyeri counties for } \\
\text { export market. } \\
\text { - 2015: Develops } \\
\text { interests in the } \\
\text { domestic market } \\
\text { segment for fresh } \\
\text { fruits and } \\
\text { vegetables. }\end{array}$ & $\begin{array}{l}\text { - Some } \\
\text { consignments } \\
\text { exceeding MRLs } \\
\text { are intercepted. } \\
\text { - Leading to } \\
\text { centralising } \\
\text { procurement of } \\
\text { PCPs and spraying } \\
\text { activities. } \\
\text { - And investing in } \\
\text { two in-house } \\
\text { business units: an } \\
\text { input store and a } \\
\text { sprayer services }\end{array}$ & $\begin{array}{l}\text { (QMS) adapted to } \\
\text { firm's context. } \\
\text { - Documents a } \\
\text { comprehensive } \\
\text { training curriculum } \\
\text { and SOPs. } \\
\text { - Upgrades technical } \\
\text { capacity of advisors to } \\
\text { implement the QMS. } \\
\text { - Develops a local } \\
\text { traceability } \\
\text { programme. }\end{array}$ & $\begin{array}{l}\text { - Acquires GLOBALG.A.P } \\
\text { certification. } \\
\text { - Acquires a direct licence } \\
\text { to export. } \\
\text { - Moots plans to expand } \\
\text { supply base to Eastern } \\
\text { region to meet the } \\
\text { break-even threshold of } \\
60 \text { tons per month. } \\
\text { - Plans to transfer some } \\
\text { quality check and } \\
\text { spraying roles to } \\
\text { growers to manage } \\
\text { costs. }\end{array}$ \\
\hline $\begin{array}{c}\text { 2013-15: Roll-out } \\
\text { phase }\end{array}$ & te & $\begin{array}{c}\text { 2018: Adapts a quality } \\
\text { management system }\end{array}$ & \\
\hline
\end{tabular}

Figure 8: Key timelines in the growth of the model

\subsubsection{Key partnerships and modifications of the model}

Instaveg has mobilised diverse public, private and civil society actors to contribute to delivering activities related to extension services (see summary in Table 10). Over time, the outgrower model has been modified to change how extension services are delivered. Stringent market requirements on MRLs and traceability and the desire to acquire a direct export licence have been major triggers for these adjustments (see Figure 8 for a timeline of the major events). 


\subsection{Evaluating performance of Instaveg's extension service from the supply-side perspective}

This section presents findings on the performance of the model from the supply-side perspective, where we examined i) uptake of AEAS and complementary services, and ii) financing and benefits of AEAS to the firm.

\subsubsection{Uptake of extension and complementary services}

According to interviews with advisors, the production team had mobilised 300 individual growers, most of them under the group contract type, between inception (2013) and December 2018. However, explicit targets on projected optimal number of contracted growers were unavailable.

Performance assessment of extension and complementary services delivery is constrained by lack of data on KPIs. However, proxy indicators suggest suboptimal performance in terms of contracting the number of growers required to meet projected production. At the time of the assessment, the firm was planning to expand supply catchment beyond the two counties in order to recruit more growers and expand the range of fresh produce. Interviews with the founder-director indicate that the supply of fresh produce has often fallen short of the break-even target of an average of 60 tons per month, sometimes as low as 10 tons per month. Further, advisors who were interviewed indicated that the business bases its production projections on moderate yields rather than on the highest potential yields.

We plan with realistic [lower] yields projections per unit. For instance, while a kilo of French beans seed [requires a plot of 0.05 acres] can potentially yield 500-700 kilos, we normally plan with a lower target yield of say 300 kilos per $\mathrm{kg}$ of seeds in order to be more realistic ... we offer an indicative buying price of KES 50-65 per kilo depending on quality.

(Interviews with a production advisor and founder-director)

This inability to meet optimal supply of produce seems to be a combination of differences between projected and realised yields as well as mismatch in seasonal patterns between prevailing local production conditions and demand for produce in the export market (see section 3.3.2 below). Lack of KPIs and data make it difficult to examine the extent to which suboptimal yields could be attributed to ineffectiveness of AEAS. However, erratic weather and incidences of pests and diseases were cited in both the farmer survey and interviews with advisors to have had negative effects on yields.

\subsubsection{Financing and benefits of extensions services to the export business}

The costs of delivering extension services are internalised in the export business and are seen as part of the operational costs of the business. Farmers therefore pay for extension services indirectly and inexplicitly through the margin retained by Instaveg on the price of sourced produce sold to endmarkets. This margin meets all the operational costs and business surplus. The founder-director indicated that the business has not yet been able to distinguish the costs and benefits of extension services to the core business of the firm.

Do we cost extension (services)? We do not really cost extension; we take it is as part of the business overheads. It is only now that we are trying to upgrade our financial management system in order to improve the financial integrity (analytics) of the business.

(Interview with founder-director)

Matching production with end-market demand is a key business objective driven by the production team. However, according to the founder-director, this objective has been elusive, largely due to a mismatch in seasonal patterns between local production conditions and market demand in Europe. According to the founder-director, the business sets production targets that are cascaded to the production team, but it has proven complex to hold them accountable, owing to external factors such as changes in weather. Another element of mismatch between production and market demand alluded to in the grower survey was incidents of Instaveg's inability to absorb excess produce during some seasons. This was a recurring reason cited by growers for dissatisfaction with Instaveg.

We experience a supply and demand mismatch for export crops ... when demand in the [European] export market is high in February to May, it is the dry season here and local production conditions are not so conducive [unless under effective irrigation system], so we don't get adequate produce ... in February and March this year (2019) we got as low as 10 tons 
per month ... when local production conditions are conducive in June to September, it is summer in Europe and therefore conducive for their own production. We therefore don't access adequate market for our produce.

(Interview with founder-director)

Another role of the production team is to ensure compliance with recommended practices from production to the collection point of fresh produce. Whereas one production advisor rated cases of sanctions in his region as low (on average $5 \%$ of suppliers), the founder-director cited cases supplies exceeding MRL as being serious enough to trigger modifications in the outgrower model. Further, according to the grower survey, $17 \%$ of farmers had an experience of been sanctioned for noncompliance. Such cases were noted to be most rampant among group-based suppliers.

\subsection{Evaluating performance of Instaveg's extension services from the demand-side perspective}

On the demand side we first analyse the profile of surveyed outgrowers, including their sources of farm advice and information, and reflect on the extent to which their characteristics match or do not with design features of the model - mainly client-targeting criteria and the value proposition. We then evaluate how the farmers implemented the advice and what changes in yield were seen on the farms.

\subsubsection{Characteristics of clients}

Forty-seven contracted growers out of a population size of 300 were sampled, drawn from Kirinyaga (74\%) and Nyeri (26\%) counties. They were sampled from villages with the highest density of contracted growers. Youth and female growers were $15 \%$ and $38 \%$ respectively.

Most respondents (83\%) were contracted under the group supply category, and $72 \%$ had three to six years of experience as growers under Instaveg (Table 11). The mean age of the growers interviewed was 47 years; the minimum and maximum were 21 and 68 years respectively. Other surveys on French bean growers in Kirinyaga have reported the mean age of growers ranging between 40.3 years (Murithi, 2008) and 42.6-45.7 years (Kibet et al., 2019).

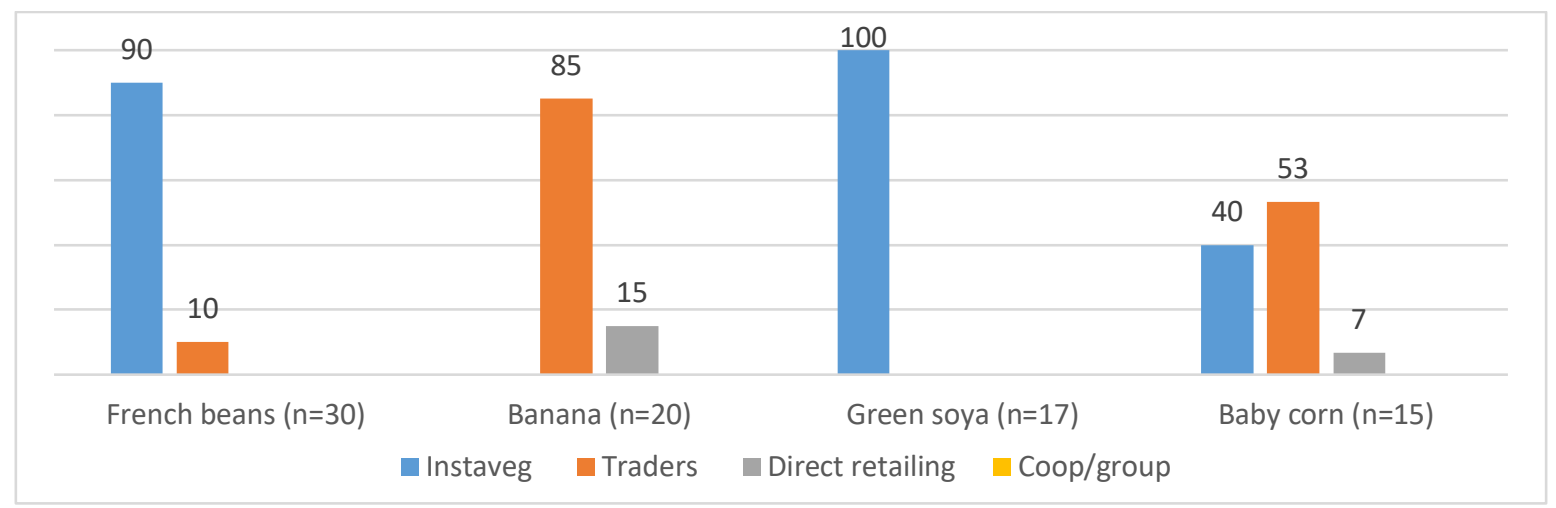

Figure 9: $\quad$ Main market outlets for leading commercial crops by percentage - Instaveg

The level of diversification of economic activities between on-farm and off-farm sources seems low. As shown in Table 11, only 30\% of respondents report engaging in off-farm occupations besides farming. However, for the on-farm activities, most respondents rank French beans (64\%), banana (43\%), green soya $(36 \%)$ and baby corn $(32 \%)$ as the leading commercial commodities. This appears to be a high level of diversification in on-farm activities. Local traders and Instaveg are the dominant offtakers of farm produce (Figure 9). The average experience as French beans growers is estimated at 14 years. Most respondents (55.4\%) had post-primary education. These years of experience as growers coupled with high literacy level implies a cohort with capacity to grasp the technical and managerial GAP content that is required to meet stringent requirements for export markets. Most growers (70.2\%) have access to small plots of land, ranging between 0.25-2.5 acres and averaging 1.5 acres. Overall, the minimum and maximum accessible land is 0.25 and 12 acres respectively, and on average 2.67 acres. All respondents had leased a plot of land, indicating an active engagement with the land 
rental market (Table 11). The average plot size under French beans was 0.88 acres compared to 0.5 acres reported in Kibet et al. (2019). Of the respondents growing French beans at the time of assessment $(n=30), 37 \%$ used plots of 0.25 acres and below (Table 11), while the two largest plots were 3 and 5 acres.

Table 11: Profile of surveyed growers - Instaveg

\begin{tabular}{|c|c|c|c|}
\hline Class & Variable & Category & Per cent \\
\hline \multirow{16}{*}{$\begin{array}{l}\text { Profile of } \\
\text { respondents/growers } \\
(n=47)\end{array}$} & \multirow[t]{2}{*}{ Gender } & Male & 62.0 \\
\hline & & Female & 38.0 \\
\hline & \multirow[t]{4}{*}{ Age (years) } & $\leq 35$ years & 15.0 \\
\hline & & $36-45$ years & 34.0 \\
\hline & & $46-60$ years & 38.0 \\
\hline & & $\geq 61$ years & 13.0 \\
\hline & \multirow[t]{4}{*}{ Education level } & No formal & 2.1 \\
\hline & & Primary & 42.6 \\
\hline & & Secondary & 51.1 \\
\hline & & Post-secondary & 4.3 \\
\hline & \multirow{4}{*}{$\begin{array}{l}\text { Year first contracted as an Instaveg } \\
\text { grower }\end{array}$} & 1 year ago & 17.0 \\
\hline & & 2 years ago & 11.0 \\
\hline & & 3 years ago & 32.0 \\
\hline & & $4-6$ years ago & 40.0 \\
\hline & \multirow[t]{2}{*}{ Supply/grower contract type } & Group-based & 83.0 \\
\hline & & Individual & 17.0 \\
\hline \multirow{16}{*}{$\begin{array}{l}\text { Economic activities and } \\
\text { resources for client } \\
\text { households ( } n=47 \text { unless } \\
\text { otherwise stated) }\end{array}$} & \multirow{3}{*}{$\begin{array}{l}\text { Three main sources of income } \\
\text { (multiple options possible) }\end{array}$} & On-farm & 100.0 \\
\hline & & Off-farm & 29.8 \\
\hline & & Remittances & 2.1 \\
\hline & \multirow{4}{*}{$\begin{array}{l}\text { Percentage of clients engaged in the top } \\
\text { four commercial crops }\end{array}$} & French beans & 64.0 \\
\hline & & Bananas & 43.0 \\
\hline & & Green soya & 36.0 \\
\hline & & Baby corn & 32.0 \\
\hline & \multirow[t]{3}{*}{ Accessible land (acres) } & $0.25-1$ & 14.9 \\
\hline & & $1.25-2.5$ & 55.3 \\
\hline & & $3-12$ & 29.8 \\
\hline & \multirow{3}{*}{$\begin{array}{l}\text { Land access rights (multiple responses } \\
\text { possible for those accessing more than } \\
\text { one plot) }\end{array}$} & Inherited & 91.5 \\
\hline & & Purchased & 38.3 \\
\hline & & Leased & 100.0 \\
\hline & \multirow{3}{*}{$\begin{array}{l}\text { Scale of operation } \\
\text { (size of plot under French beans) } n=30\end{array}$} & $\leq 0.25$ acres & 37.0 \\
\hline & & $0.26-0.99$ acres & 30.0 \\
\hline & & $1-5$ acres & 33.0 \\
\hline
\end{tabular}

\subsubsection{Main sources of farming advice and information accessed by respondents}

Private sector actors are the dominant sources of advice and information about horticulture farming, with Instaveg and private input suppliers taking the lead (Figure 10). Most interviewed outgrowers (89\%) reported they had accessed Instaveg-facilitated extension services, mostly in forms of farm visits and regular group meetings organised by production advisors and centralised group training cofacilitated by Instaveg and partners. However, it would be expected that all outgrowers access extension services as a requirement under the outgrower scheme. This variance is due to two major reasons: first, outgrowers under a group contract are regarded as a single supplier/entity, such that farm visits by Instaveg advisors are made to a sample of plots; second, Instaveg advisors communicate slots for centralised group training to group leaders, who in turn nominate group members. It was reported that under this arrangement a bias has been to nominate group leaders since they are expected to monitor and train members. For most other providers, advice is embedded in the sale of inputs or supply of produce and respondents tend to perceive them as free, since they do not pay directly and explicitly. Most respondents (60\%) reported that they do not use their phones to access farming advice and information.

Accessing a reliable market for produce (positive market signal) is the most cited reason for signing up to the outgrower programme. All growers interviewed were conversant with the terms of engagement outlined in the contract. Farm (scouting) visits and group-based training were reported as the most common extension delivery methods. Most respondents (64\%) reported being satisfied to very 
satisfied with their relationship with Instaveg. The 36\% expressing low levels of satisfaction (neutral/dissatisfied) cited concerns related to buying prices and payment conditions, rejections of produce and gaps in services facilitated by Instaveg (Table 12). Further, concerns were raised about low levels of transparency associated with the practice of keeping aggregated records for group-based suppliers, as compared to individualised grower records. Hotline calls, talks with Instaveg advisors during visits, and petitioning group leaders are the main feedback mechanisms used by respondents.

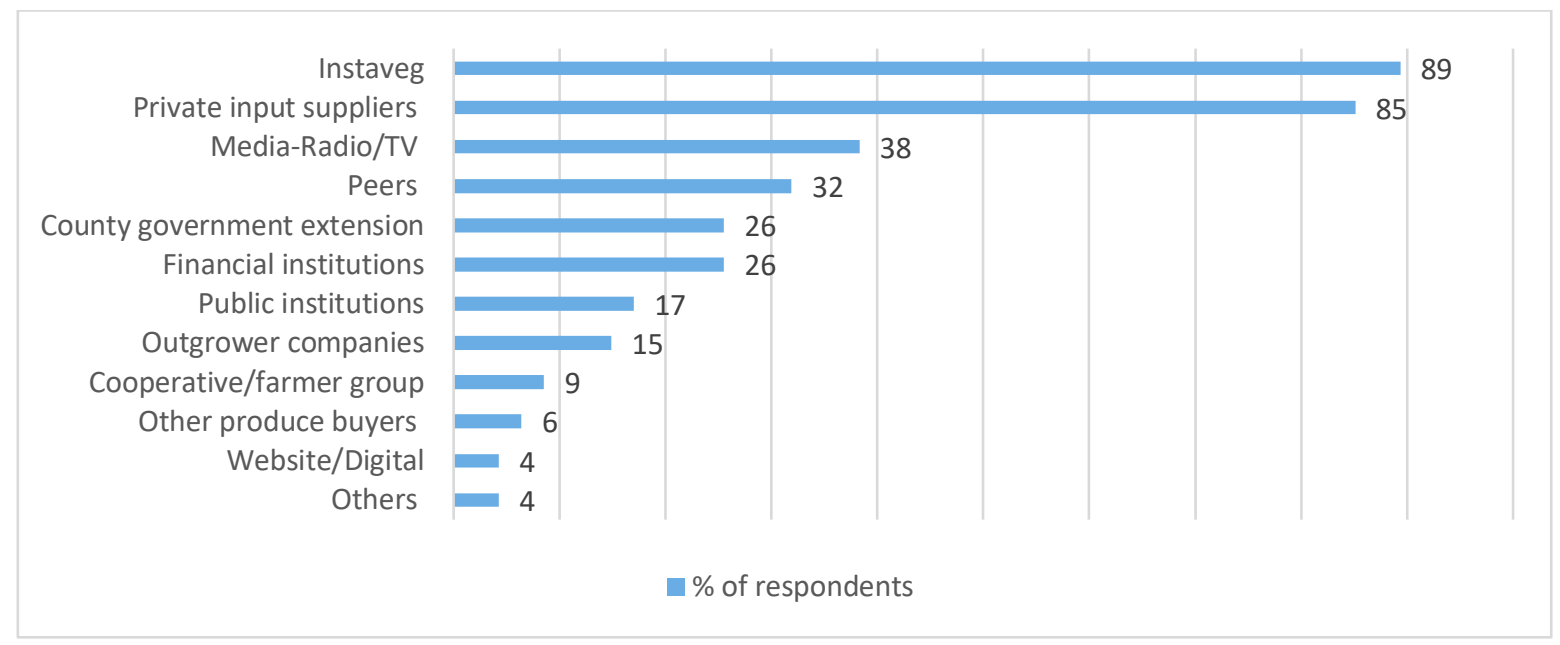

Figure 10: Main sources of advice and information on horticulture- Instaveg $(n=47)$

Table 12: Reasons for low levels of satisfaction with Instaveg services

\begin{tabular}{|c|c|}
\hline Nature of reason & Some of reasons the for being neutral and/or dissatisfied \\
\hline Payment conditions & Occasional delays, unclear deductions \\
\hline Rejections & $\begin{array}{l}\text { Frequent cases of rejection due to 'alleged' poor quality, exceeding supply } \\
\text { quota }\end{array}$ \\
\hline Prices & $\begin{array}{l}\text { Low (perceived), fluctuations, lowering rates allegedly based on quality of } \\
\text { produce }\end{array}$ \\
\hline Gaps in services & $\begin{array}{l}\text { Failure to offer fertiliser on credit, advance payments and on-the-spot grading } \\
\text { at collection; failure to target other key commercial crop enterprises (banana, } \\
\text { tomato, carrot, pepper); failure to address complex problems hindering yields } \\
\text { despite following advice (effects of erratic weather and pests and diseases } \\
\text { outbreak) }\end{array}$ \\
\hline
\end{tabular}

\subsubsection{Implementation of advice}

Most respondents ( $85 \%$ ) report they have improved their farm planning and management practices since they joined the outgrower programme (Figure 11). But there were limitations in adoption of improved practices such as inaccessibility of financing, and rampant incidents of produce being rejected. Some respondents (17\%, most of them group-based suppliers) reported experiencing a temporary suspension in supplying produce due to non-compliance.

Overall, most (62\%) respondents cite improvements in farm use planning in terms of decisions on choice and mix of commodities. Adoption of improved practices related to application of inputs (34\%), crop maintenance $(19.1 \%)$ and harvesting (10.6\%) were noted to be low. These could be due to high costs of input and labour for harvesting, especially in the case of French beans which was reported to be the most intensive, costly and back-breaking activity. Harvesting is mostly undertaken by women who are paid KES 10 per kilo and payment is expected to be done daily. Considering that Instaveg was paying growers KES 50 to 65 per kilo of French beans, the cost of hired labour for harvesting takes $20-15 \%$ of total revenue accruing to growers. To offset this cost, Instaveg offers advance payment to growers on request. Daily wages for other farm maintenance operations were estimated at an average of KES 350 per worker per day. Although cases of group members organising for collective labour arrangements were reported, sourcing hired labour was noted to be inevitable. 


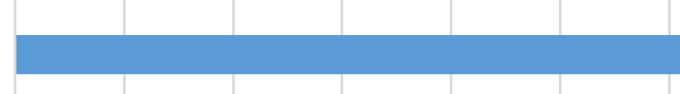

\section{Input application (timeliness) \\ Crop maintenance (weeding, land prep.)}

Harvesting (right time to harvest, handling practices)

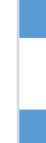

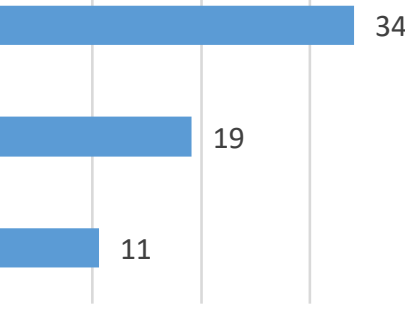

34

[ \% of respondents

(1)

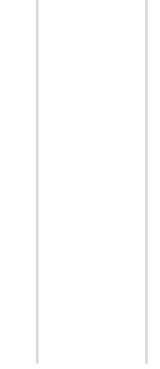

Figure 11: Farmers adoption of improved farm practices - Instaveg $(n=47)$

\subsubsection{Changes in yield and other farm-level outcomes}

From the respondents $(n=37)$ who provided self-reported yield data on the main commercial crops French bean and green soya, 43\% reported an improvement based on their own set targets over two to three seasons from running mid-2018 to early 2019 . Another $22 \%$ reported yields to have fluctuated (i.e. experienced at least an improvement followed by a decline) between the three seasons in reference (Figure 12). Interviews with farmers and Instaveg staff suggested negative effects of erratic weather and outbreak of pests and diseases as major factors for observed poor performance in expected yields.

Most respondents ( $81 \%$ ) attribute positive changes in family wellbeing to participation in the outgrower programme. These are mainly related to increased incomes in terms of amount and frequency of flow, and ability to meet education expenditures. Respondents also affirm that the outgrower programme has contributed positively to farmers working together (98\%) and in linking growers with other agribusiness partners (75\%). Most respondents observe that the outgrower programme does not directly discriminate against men or women as growers $(83 \%)$.

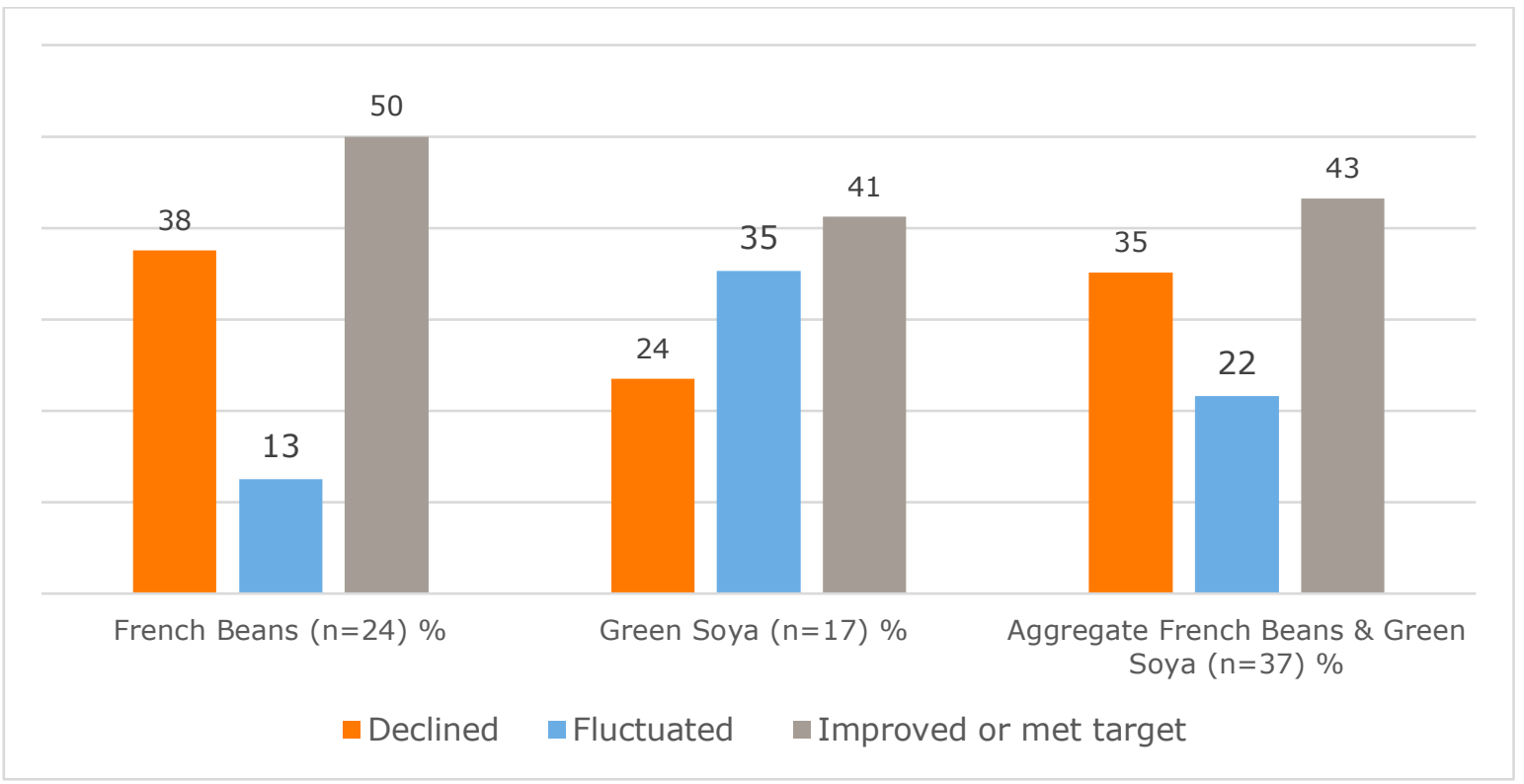

Figure 12: Changes in yield in last three seasons vs own targets - Instaveg 


\subsection{Conclusions and recommendations on the Instaveg model}

In this section we refer to the key questions guiding this assessment to draw conclusions and identify attention areas/recommendations.

\subsubsection{The design and operationalisation of the model}

Instaveg's extension services approach could be considered typical for outgrower models linked to export markets for fresh horticultural produce originating from Kenya. It has enabled an estimated 300 farmers to access export markets, expanding both their economic participation and their knowledge of how to meet stringent quality and food safety requirements. Instaveg has continued to improve the overall design of its business model to improve the relevance and effectiveness of the outgrower model in general, as well as elements specific to delivery of AEAS, including introduction of complementary services such as spraying teams and central stores for PCPs. However, the exact costs and benefits of extension services to Instaveg as a business and the effectiveness of the AEAS remain a blind spot. Improving analytics on the costs and benefits of investing in AEAS is considered a critical step to improving the design and performance of Instaveg's overall business model.

\subsubsection{Relevance and effectiveness of extension services to outgrowers}

Most producers (70.2\%) are smallholders, averaging 1.51 acres, but Instaveg's outgrower model has enabled them to participate in high-value crop markets. While the biophysical conditions in Kirinyaga and Nyeri are suitable for high-value fruit and vegetable production, institutional innovation linking production to markets is required. As noted, these commodities are subject to stringent food quality and safety requirements in the export markets, amid a context of changes in pests and diseases prevalence and weather patterns.

A model, therefore, that links farmers to knowledge and skills that help them keep abreast of the changing production environment and market conditions is highly relevant. Proxy data on farm-level outcomes suggests outgrowers can increase yields and productivity (Figure 12), especially when market signals are positive. Thus, we see that AEAS, linked to inputs and then markets, work in tandem. To further improve knowledge access and use, we point to the need for Instaveg to invest in a robust on-farm data management system that is intended to support farm-level decision support as much as it supports the overall business model. It is important for an integrated system that goes beyond the aggregate business to farmer level outcomes and is considered key in demonstrating the co-shared value of the model between the firm and the outgrowers.

\subsubsection{Inclusiveness, financial sustainability and scalability}

We observe that the model targets individual growers operating at a larger scale and/or small-scale growers if organised in a group. We further noted that leasing land was a common practice and perhaps makes land more accessible to resource-poor growers than purchase. The model does not explicitly target youth and women growers. However, proxy (survey) data suggests a relatively high proportion of youth (15\%) and women (38\%).

The sustainability of the extension services depends on the financial performance of the firm. In turn, this financial performance is influenced by tonnage of produce off-taken and sold in targeted market segments. The business has not been meeting its break-even target of an average of 60 tons of produce per month, sometimes reporting a low of 10 tons per month. Instaveg plans are to expand both product and market segments. These plans entail some elements of scaling in terms of expanding grower catchment areas, recruiting additional growers and expanding the range of crops and production knowledge. 


\section{Case 3: Perfometer's dairy advisory services model}

\subsection{About the business}

The interview with the founder-director of Perfometer Agribusiness Limited (PAL) and review of business reports provided insights about the background and genesis of the model. PAL is a private, independent dairy advisory and consultancy firm registered in 2013 in Nairobi. The firm was set up to offer knowledge and advisory services to medium-scale farms (MSFs) as a potentially niche market for a private advisory business. The firm start-up was supported by SNV's Kenya Market-led Dairy Programme (KMDP), which at the time was keen to stimulate development of a cadre of private dairy advisory service models under a local capacity-building initiative. This recognised the emerging segment of MSFs that were entrepreneurial and seeking trusted knowledge and advisory support to grow their farm enterprises and that would be willing to pay for this support. PAL was supported by KMDP to stimulate demand for private advisory services in the MSFs segment and build capacity of PAL advisors - mainly by pairing them with Dutch experts for coaching and organising training and exchange visits to the Netherlands' advanced dairy industry.

\subsection{Design of PAL's private dairy advisory services model}

Dairy farming is fuelled by knowledge but driven by passion. ( http://perfometer.co.ke/about/)

Interviews with the founder-director and advisors and review of business documents and reports (Creemers, 2017; Perfometer, 2019) provided details on the design and operationalisation features of the PAL model. Since beginning operation slightly more than six years ago, PAL has evolved from its start-up phase into a growing, innovative business. It started as an agribusiness consulting house with interests in a range of agricultural subsectors and commodities, before making a business policy decision to focus on dairy advisory and consultancy services. PAL's value proposition is 'to support practising and start-up investors to run profitable dairy production enterprises by providing professional and independent dairy advisory and consulting services. To deliver this value, PAL developed a suite of connected advisory products. Services are benchmarked against international standards from advanced dairy industries such as the Netherlands. This section describes the services package and other design elements of the model.

\subsubsection{Client targeting, business development, costing and financing}

PAL'S AEAS is an independent, professional and private advisory and consulting services approach that is not linked to input delivery. PAL's services target two client segments: commercial and projects. The latter targets organisations and development projects that subcontract PAL to offer services to their beneficiaries (including small-scale dairy farmers organised into dairy cooperatives). PAL services have no specific geographic coverage but are guided by client demand. At the time of this assessment, PAL had commercial clients spread across 14 counties.

This study focused mainly on the commercial segment, which targets existing or aspiring dairy farm investors operating at an average scale of at least 100 litres per day or 10 lactating cows. For this segment, the business strategy is to retain a portfolio of clients that is manageable for the current set of advisors and organisational capacity. As a result, PAL does not use mass media to advertise its services, but rather relies on referrals. The firm has further tightened its client screening procedures to ensure it attracts serious potential clients. Some of these screening procedures include some pseudo-products or activities such as impression farm visits, reconnaissance visits for some new clients seeking the farm master planning product, and family meetings to gauge the extent of shared vision within a prospective client's family. Perfometer charges at cost recovery rate for these screening activities. The firm observes that serious clients tend to be aged 46-60 years, and as a result has been exploring approaches to engage young dairy investors, as they are perceived to be more speculative. 
Table 13: Profile of the main commercial segment advisory products offered by PAL

\begin{tabular}{|c|c|c|c|c|}
\hline $\begin{array}{l}\text { Product } \\
\text { (year launched) }\end{array}$ & Value proposition and description & Delivery approach and output & $\begin{array}{l}\text { Uptake by } \\
2018\end{array}$ & $\begin{array}{l}\text { Indicative } \\
\text { price (KES) }\end{array}$ \\
\hline $\begin{array}{l}\text { Dairy Farm } \\
\text { Benchmarking (DFB) } \\
(2014)\end{array}$ & $\begin{array}{l}\text { Holistic diagnostic tool for pre-existing farms. } \\
\text { Recommended as entry product for new clients. } \\
\text { Improved recently to include farm KPIs. }\end{array}$ & $\begin{array}{l}\text { Mix of on- and off-farm sessions. A team of five in- } \\
\text { house advisors (specialists for different aspects). } \\
\text { Assessment report (scores, gaps and } \\
\text { recommendations) }\end{array}$ & 53 & $50,000 /$ farm \\
\hline $\begin{array}{l}\text { Dairy Master Plan (DMP) } \\
\text { and Farm Improvement } \\
\text { Plans (FIP) (2016) }\end{array}$ & $\begin{array}{l}\text { Serves as the strategic business plan for a farm. It } \\
\text { analyses the required investments. DMP is ideal for start- } \\
\text { up farms, while FIP is a post-DFB product. }\end{array}$ & $\begin{array}{l}\text { A team of advisors. Currently PAL outsources expertise } \\
\text { for some aspects (e.g. financials). Involves site visits. A } \\
\text { written plan is presented. }\end{array}$ & 55 & $\begin{array}{l}300,000- \\
400,000 / \\
\text { farm }\end{array}$ \\
\hline $\begin{array}{l}\text { Academy of Dairy } \\
\text { Investors (ADI) (2015) }\end{array}$ & $\begin{array}{l}\text { Aims to acquaint practising and aspiring investors with } \\
\text { SOPs for running a successful dairy farm (focus on } \\
\text { investments and returns). }\end{array}$ & $\begin{array}{l}\text { A one-week workshop with a one-day practical session } \\
\text { in a partnering farm. PAL outsources some experts as } \\
\text { trainers and targets } 25 \text { trainees as optimal. }\end{array}$ & $\begin{array}{l}6 \\
\text { sessions }\end{array}$ & $\begin{array}{l}69,500 / \\
\text { person }\end{array}$ \\
\hline $\begin{array}{l}\text { Academy of Dairy } \\
\text { Managers (ADM) (2015) }\end{array}$ & $\begin{array}{l}\text { Practical dairy farm training for farm managers and } \\
\text { aspiring managers. Unlike the ADI, ADM focuses more on } \\
\text { farm routines and supervision. }\end{array}$ & $\begin{array}{l}\text { A one-week workshop in a practical farm setting. } \\
\text { PAL outsources some local and international experts as } \\
\text { trainers and targets } 25 \text { trainees as optimal. }\end{array}$ & $\begin{array}{l}7 \\
\text { sessions }\end{array}$ & $\begin{array}{l}35,200 / \\
\text { person }\end{array}$ \\
\hline $\begin{array}{l}\text { On-Farm Coaching } \\
\text { (OFC) }(2016)\end{array}$ & $\begin{array}{l}\text { Designed to train workers on the job, at the farm setting } \\
\text { and in simple language. It has been used to introduce new } \\
\text { advisory tools, e.g. Rumen8 (on feed rationing), and use of } \\
\text { KPI data to inform advice. }\end{array}$ & $\begin{array}{l}\text { On-farm visits by a specialist PAL advisor. Supported } \\
\text { by other advisors, depending on farm needs. }\end{array}$ & 45 farms & $8,000 /$ farm \\
\hline $\begin{array}{l}\text { Dairy World Magazine } \\
\text { (2017) }\end{array}$ & $\begin{array}{l}\text { Serves as a trading brand for PAL and a platform where } \\
\text { farmers can share their experiences, advisors can } \\
\text { document insights and firms advertise services. }\end{array}$ & $\begin{array}{l}\text { Available in print and online versions. Targets a } \\
\text { regional audience (East Africa). }\end{array}$ & 3 issues & $\begin{array}{l}\text { 300/hard } \\
\text { copy }\end{array}$ \\
\hline $\begin{array}{l}\text { Cow barn design plan } \\
(2015)\end{array}$ & $\begin{array}{l}\text { Targets two main needs that were found to be poorly } \\
\text { addressed: high standards for cow comfort and holistic } \\
\text { farm planning with optimised land use. }\end{array}$ & $\begin{array}{l}\text { Customised plan and costing plan (design). } \\
\text { Construction and/or supervision services (optional). }\end{array}$ & $\begin{array}{l}51(42 \\
\text { design } \\
\text { only) }\end{array}$ & $\begin{array}{l}95,000 / \\
\text { design only }\end{array}$ \\
\hline $\begin{array}{l}\text { International exchange } \\
\text { visits ( } 2014 \text { to } 2015 \text { ) }\end{array}$ & $\begin{array}{l}\text { Exposed farmers and prospecting investors to international } \\
\text { standards and experiences in the Netherlands. }\end{array}$ & $\begin{array}{l}\text { International visits were scaled down in 2016. PAL } \\
\text { instead links clients with peers (in an alumni kind of } \\
\text { setting). }\end{array}$ & 2 & $\begin{array}{l}100,000 \\
\text { subsidised } \\
\text { rate/person }\end{array}$ \\
\hline CowPro app (2019) & Dairy herd management and fodder-sourcing platform/app. & Digital & New & Embedded \\
\hline $\begin{array}{l}\text { Dairy farm accounts } \\
\text { (2019) }\end{array}$ & $\begin{array}{l}\text { Bookkeeping and financial analysis services. Workforce } \\
\text { management and tax compliance. }\end{array}$ & Farm visits and/or records delivered to PAL offices. & New & $\begin{array}{l}120,000 / \\
\text { farm/year }\end{array}$ \\
\hline
\end{tabular}


Table 14: Cost structure for PAL advisors

\begin{tabular}{lcc}
\hline Cost items (average monthly costs) & Current rates (KES) & $\begin{array}{c}\text { \% contribution of } \\
\text { items to total monthly } \\
\text { cost }\end{array}$ \\
\hline Professional fees for an advisor & $75,000-200,000$ & $70.2-86.1 \%$ \\
\hline Subsistence (meals and accommodation) & 20,000 & $18.6-8.7 \%$ \\
\hline Transportation to farms & 12,000 & $11.2-5.2 \%$ \\
\hline
\end{tabular}

Table 13 presents the main dairy advisory products, their value proposition, delivery approach, when they were first launched and indicative pricing. Largely, products have evolved organically, building on findings of initial thematic studies undertaken by KMDP, exposure to the Dutch dairy industry experiences and actual interactions with end users and clients. PAL has relied on international (mainly Dutch) and local dairy experts to validate the content and quality of its advisory products.

Table 14 presents the cost structure for advisors. The overall delivery approach relies on an in-house team of advisors, with most services being offered by a team, advisors rather than a single advisor. The advisor: client ratio under the model is flexible, but with limitations, depending on the number of clients seeking services, the nature of advisory products sought and the geographical spread of client farms. Additionally, PAL teams up, sometimes through an outsourcing arrangement, with local and international experts from academia, research and private providers of dairy inputs and services to deliver some of the inputs. Some advisory products require on-farm delivery, while others are nonfarm advisory products. On-farm advisory products tend to be individualised and offering opportunity for long term support, while non-farm ones tend to be group-based.

Outsourcing of advisory services is mainly done for non-farm advisory products such as ADM and ADI. The frequency and contact time per farm visit and the composition of advisor team required depends on the product(s) being offered. Some visits tend to be diagnostic in nature, collecting either baseline (such as first DFB) or progress data (e.g. KPIs in follow-up on DFB implementation); others are about sharing results and recommendations or tangible outputs such as customised cow barn design layout and DMP (and can be off-farm meetings); while others are scheduled visits to provide advice or support on specific problems/solutions and practices (preparing feed rations, fodder establishment/harvesting or conservation).

Application of media and ICT-based delivery methods seem to be less exploited, though plans to develop videos and animated (online) content were indicated (interview with founder-director). Peer learning methods were scaled down as they were found to be less attractive to urban-based MSFs. PAL had also developed a DairyWise handbook for dairy managers and supervisors and intends to convert most SOPs into handbooks and online resources. Overall, PAL's content has heavily borrowed from the Dutch dairy knowledge system.

\subsubsection{Advisors profiles, roles and deployment}

The team of 12 in-house advisors (seven females) holds a minimum of a bachelor's degree in a mix of disciplines, including livestock/animal sciences, agronomy, economics, finance and accounting, and architecture. The part-time advisor who implements OFC was an exception as a diploma holder with extensive practical experience in commercial dairy farms. In addition, entry-level advisors are expected to successfully go through PAL's three to six months induction and probation process. This includes self-directed reading of recommended reference resources - mostly content drawn from the Dutch dairy industry and other international contexts.

While all AEAS products call for specialisation among advisors, others are the reserve of a cadre of senior advisors (three senior advisors by time of assessment) such as DFM, ADM and ADI. Besides delivering their assigned technical roles satisfactorily, advisors are expected to maintain a good working relationship with clients. Start-up advisors in the first group were mentored by Dutch experts, mainly in the areas of fodder and animal husbandry. PAL holds four staff learning days per year on either technical or functional topics, such as report writing.

Whereas advisors are not explicitly tasked with recruiting clients or product development, their contribution towards growing the business is part of their annual appraisals. The main roles played by 
the director are to lead product development, quality assurance and coaching, introduce new advisors to clients, attend to difficult clients and administration and management.

Some advisory products - such as cow barn design, fodder production and non-farm advisory products - have proven more challenging to develop the requisite skills in (interview with founder-director; Creemers, 2017). For cow barn design, PAL had to expose a local architect to extensive training in the Netherlands. For fodder production, the dilemma has been that local agronomy or horticulture graduates have little background in animal nutrition, while animal science graduates have minimal background in agronomy (crop and soil science) (interview with founder-director). According to Creemers' 2017 assessment, the development and marketing of most non-farm advisory products need capacity development, as they require different advisory skill sets from on-farm advisory.

\subsubsection{Key partnerships, modifications and lessons in operationalising the model}

According to the founder-director, PAL has relied on partnerships with public and private sector actors to commercialise dairy advisory as a business service (Table 15), with SNV/KMDP being a unique and unparalleled partner in the category of non-profit collaborators.

KMDP has treated us with gloves, unlike most other project segment clients who have tended to use bare knuckles in our business relationship ... some project segment clients have penalised us for unsatisfactory service delivery ... they have treated us as a mature business in cases where KMDP would choose to support us to improve the delivery and in the process enhance our capacity.

(Interview with founder-director)

Table 15: Summary of main public and private partnerships established by PAL

\begin{tabular}{|c|c|}
\hline Partners & Description of areas of collaboration \\
\hline SNV/KMDP & Start-up support - financial and technical \\
\hline Dutch private sector & Explore business-to-business partnerships (e.g. Cow Signals, The Friesian) \\
\hline $\begin{array}{l}\text { Dutch dairy } \\
\text { knowledge actors }\end{array}$ & Coaching and mentoring PAL advisors (e.g. PUM, under KMDP) \\
\hline CTA & $\begin{array}{l}\text { Implementation of Dairy PROFIT Project, support in development of CowPro } \\
\text { app }\end{array}$ \\
\hline $\begin{array}{l}\text { Strathmore } \\
\text { University Business } \\
\text { School }\end{array}$ & $\begin{array}{l}\text { PAL serves as an advisor on dairy in Strathmore's business school of dairy } \\
\text { enterprises and co-organises short training courses on dairy }\end{array}$ \\
\hline $\begin{array}{l}\text { Clients' farms } \\
\text { (Oloosian, Joy, } \\
\text { MEVED) }\end{array}$ & $\begin{array}{l}\text { For hosting practical training sessions (ADI/ADM), piloting new tools } \\
\text { (Rumen } 8 \text { ) and hosting trainee farm workers participating in PAL's coaching } \\
\text { programmes for on-the job training sessions }\end{array}$ \\
\hline University of Nairobi & PAL outsources expertise on animal nutrition \\
\hline $\begin{array}{l}\text { Development } \\
\text { projects and other } \\
\text { organisations } \\
\text { (are mainly project } \\
\text { segment clients but } \\
\text { are not the end } \\
\text { users of PAL } \\
\text { advisory services) }\end{array}$ & $\begin{array}{l}\text { Mainly subcontract PAL to provide advisory support to smallholder dairy } \\
\text { farmers and cooperatives and/or value chain related studies, for example: } \\
\text { East Africa Dairy Development Programme, Cooperative Federation for } \\
\text { German Cooperatives, Ministry of Commerce in Rwanda, Forum for } \\
\text { Agriculture Research in Africa in Ghana and VI-Agroforestry (Eastern Africa), } \\
\text { DairyBISS (Ethiopia), Cooperative Alliance of Kenya, Eastern Africa Farmers } \\
\text { Federation, Tanzania Federation of Cooperatives }\end{array}$ \\
\hline
\end{tabular}

Considered a unique and innovative start-up, PAL has a suite of advisory products (targeting commercial clients) that has evolved organically in response to identified and stimulated needs and problems in targeted clients and their farms - with a focus on dairy husbandry and fodder. Admittedly, the model's focus during the start-up period has been more on product development and client activation than on generating surplus (interview with founder-director). These products have been found to be effective tools in starting to create awareness and trigger attitude and behaviour change in the Kenya dairy sector (Creemers, 2017). The model is transitioning towards a more robust on-farm data-driven approach to deepen the quality of advisory services. Table 16 in the following section presents a summarised analysis of how experiences with initial advisory products have influenced the refinement and evolution of some of the key products and tools. 
The found-director highlighted that a key lesson has been the limited availability of dairy advisors who were able to work immediately in the model. This has been attributed to:

1. Lack of a pool of ready-to-hire graduates: "There are no ready-to-employ graduates like say, in the accounting profession, and as pioneers we have limited organisations where we can poach advisors meeting our requirements." (Interview with founder-director)

2. High costs of developing an entry-level graduate to a senior advisor with the high levels of professionalism and specialist knowledge increasingly demanded by the client base. "It takes us on average three years to orient and transform the most motivated entry-level advisors into full-fledged advisors." (ibid).

3. Advisor attrition for the model was $50 \%$. The common routes for attrition were poaching by Dutch inputs and services providers or the entrepreneurial drive of advisors to set up their own business operation.

\subsection{Evaluating performance of PAL's advisory services from the supply-side perspective}

This section presents findings on the performance of the model from the supply-side perspective, where we examined i) uptake of AEAS and complementary services, and ii) financing and benefits of AEAS to the firm.

\subsubsection{Uptake of dairy advisory and complementary services}

Review of PAL's business documents (Perfometer, 2018, 2019) and the interview with the founderdirector revealed that uptake of services has grown over the years both in terms of the number of clients taking up specific service products and in the diversity of those products (Figure 13). By the end of 2018, PAL had served 205 MSFs in Kenya. However, lack of targets on projected uptake hinders critical evaluation of this performance.

As a business policy, PAL has been reluctant to engage in facilitating access to dairy inputs and other complementary services in order to safeguard the independence and neutrality of advisory and consulting services offered. However, this position has posed dilemmas over the years as clients request guidance on where to access quality inputs and other support services, they need to implement the dairy advice provided. This has seen PAL get involved in, for example, facilitating linkages between commercial fodder producers/suppliers and client farmers and moving beyond provision of design and advisory services on cow barns to actual implementation of the civil

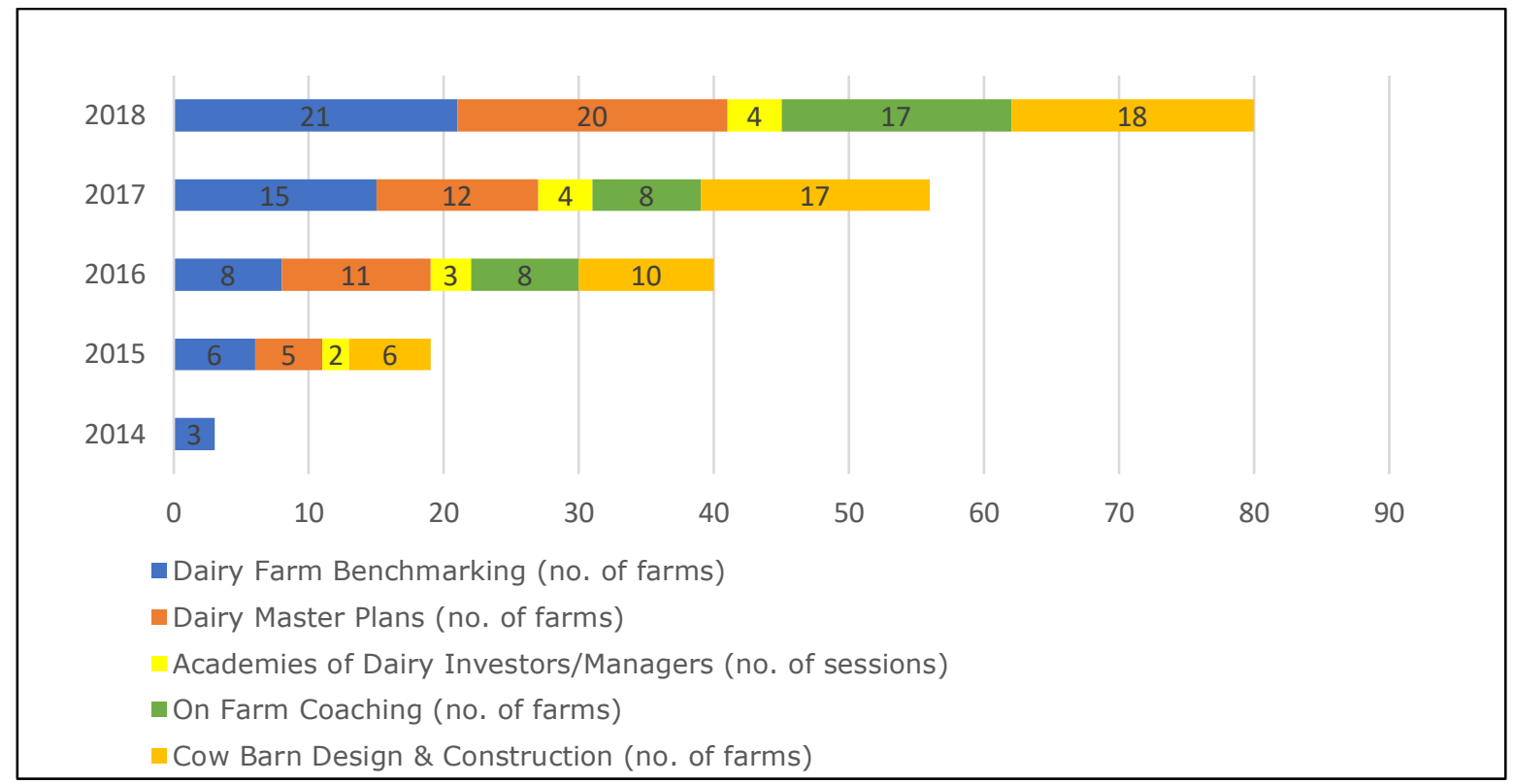

Figure 13: Trends in uptake of selected advisory service products per year - PAL 
links dairy farms with quality-assured sources of fodder. The involvement in input delivery has created works/construction phase (the turnkey option). One of PAL's recent advisory tools - the CowPro app some tensions. Some clients interviewed expressed dissatisfaction with the quality of fodder accessed via PAL's recommendation, and another client indicated that they had discontinued their relationship with PAL due to poor workmanship in the construction of a cow barn. These sentiments perhaps point to the inherent risks of bundling complementary inputs and services in the context of the PAL model. In response to these tensions, PAL's founder-director indicated that a decision had been taken to form a subsidiary company that would provide complementary services.

Table 16: How assessment of PAL's advisory products has influenced service modifications

\begin{tabular}{|c|c|c|c|}
\hline Product/theme & Observed effects & Attention areas & $\begin{array}{l}\text { Improvements } \\
\text { taken }\end{array}$ \\
\hline DFB & $\begin{array}{l}\text { - Has served as a mirror } \\
\text { and trigger for } \\
\text { behaviour change } \\
\text { - An effective tool for } \\
\text { structuring advisor- } \\
\text { client engagement } \\
\text { - Effective in rating } \\
\text { technical performance } \\
\text { of farms } \\
\text { - The farm } \\
\text { profile/glance page is } \\
\text { a useful dashboard }\end{array}$ & $\begin{array}{l}\text { Post-DFB follow-up is critical } \\
\text { and will require: } \\
\text { - specialised advice } \\
\text { - continuous monitoring } \\
\text { - regular farm data collection } \\
\text { and analysis. } \\
\text { Tool needs to incorporate: } \\
\text { - financial data } \\
\text { - on-farm fodder production } \\
\text { - guidance on "ideal farm" } \\
\text { concept }\end{array}$ & $\begin{array}{l}\text { Incorporation of } \\
\text { the KPI tool to } \\
\text { address weakness } \\
\text { of data and } \\
\text { analytics }\end{array}$ \\
\hline FIP & $\begin{array}{l}\text { A useful product in } \\
\text { guiding post-DFB support }\end{array}$ & $\begin{array}{l}\text { Should indicate specific } \\
\text { activities, time frames, } \\
\text { expertise needed and KPIs }\end{array}$ & Upgraded to DMP \\
\hline $\begin{array}{l}\text { Cow barn design } \\
\text { and construction }\end{array}$ & $\begin{array}{l}\text { - Clients are likely to } \\
\text { take shortcuts, e.g. } \\
\text { hire less experienced } \\
\text { architects and } \\
\text { contractors } \\
\text { - The few farms that } \\
\text { have adhered to } \\
\text { advice have noticed } \\
\text { the results (e.g. high } \\
\text { roof = high cow } \\
\text { comfort and high } \\
\text { performance) }\end{array}$ & $\begin{array}{l}\text { - New structures need to be in } \\
\text { line with a farm's holistic } \\
\text { plan } \\
\text { - This consultancy requires PAL } \\
\text { advisors to be involved from } \\
\text { start to end to minimise } \\
\text { avoidable mistakes } \\
\text { - Exposure to different farming } \\
\text { systems and cow barn } \\
\text { designs }\end{array}$ & $\begin{array}{l}\text { Expansion to } \\
\text { provide contractor } \\
\text { services (turnkey } \\
\text { approach) and } \\
\text { construction } \\
\text { supervision role }\end{array}$ \\
\hline $\begin{array}{l}\text { Fodder and } \\
\text { feeds }\end{array}$ & $\begin{array}{l}\text { Most farms sampled } \\
\text { (6/8) were implementing } \\
\text { DFB and had improved } \\
\text { their feeding regimes } \\
\text { (though sample size is } \\
\text { small } 8 / 53 \text { ) }\end{array}$ & $\begin{array}{l}\text { Expanding the module to } \\
\text { include: } \\
\text { - quality analyses of existing } \\
\text { feeds } \\
\text { - ration calculation } \\
\text { - } 1-2 \text { years feed planning } \\
\text { advice }\end{array}$ & $\begin{array}{l}\text { Led to piloting of } \\
\text { Rumen } 8 \text { as a feed } \\
\text { planning tool in } \\
2018\end{array}$ \\
\hline $\begin{array}{l}\text { Herd } \\
\text { management }\end{array}$ & $\begin{array}{l}\text { Most farms sampled } \\
(6 / 8) \text { implementing DFB } \\
\text { had made good steps in } \\
\text { herd management } \\
\text { aspects }\end{array}$ & $\begin{array}{l}\text { To deepen the quality of } \\
\text { advice, historical sets of farm } \\
\text { data and analysis will be key } \\
\text { going forward }\end{array}$ & $\begin{array}{l}\text { Led to launch of } \\
\text { CowPro app in } \\
\text { June } 2019\end{array}$ \\
\hline $\begin{array}{l}\text { Workforce } \\
\text { management }\end{array}$ & $\begin{array}{l}\text { Some farms had a more } \\
\text { stable and skilled } \\
\text { workforce than others }\end{array}$ & $\begin{array}{l}\text { ADM/ADI are relevant products } \\
\text { and need to be scaled to more } \\
\text { farms }\end{array}$ & $\begin{array}{l}\text { Led to OFC } \\
\text { product }\end{array}$ \\
\hline Record-keeping & $\begin{array}{l}\text { Has not picked up as } \\
\text { expected; low uptake of } \\
\text { herd management } \\
\text { systems }\end{array}$ & $\begin{array}{l}\text { Reasons for low uptake: } \\
\text { - high costs of software } \\
\text { - inadequate skills } \\
\text { - limited data analysis } \\
\text { expertise within PAL }\end{array}$ & $\begin{array}{l}\text { Led to piloting of: } \\
-\quad \text { KPI tool } \\
-\quad \text { CowPro app } \\
-\quad \text { dairy } \\
\quad \text { accounts }\end{array}$ \\
\hline
\end{tabular}

Source: Creemers (2017); column on remedial measures is based on observations for this assessment. 


\subsubsection{Financing of AEAS and benefits of AEAS to PAL's business}

PAL has experienced growth in turnover while gradually diversifying revenue streams, moving from depending on KMDP as the primary source of financing by increasing contributions from commercial clients and other project segments. Figure 14 presents these annual changes in revenue contribution from different sources/segments. PAL's strategy has been to charge a lower margin for commercial clients compared to project clients. Internal business data accessed for this assessment suggest that revenue contribution from the commercial segment has grown from 2\% in 2014 to $16 \%$ in 2018 (Figure 14). Data for the 2015-2017 business years was not readily available. This would have provided more robust analytics.

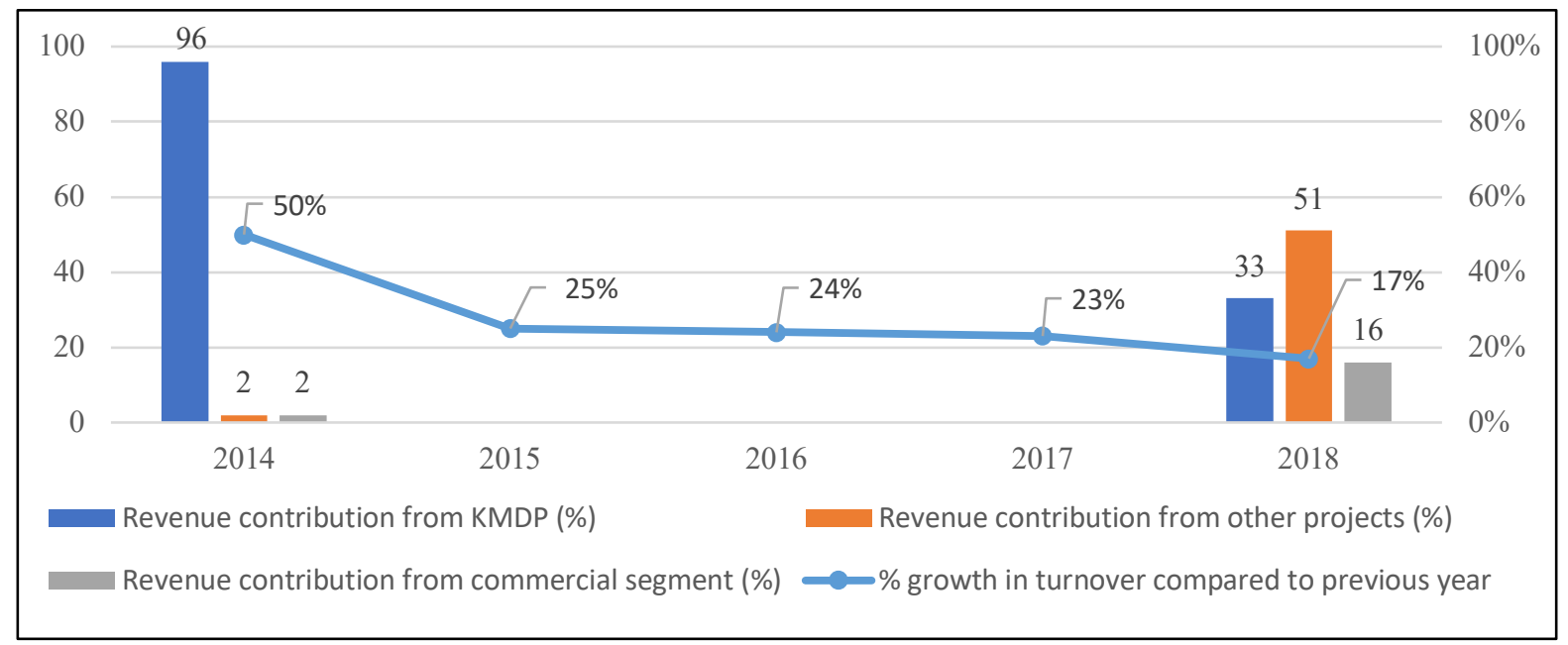

Figure 14: $P A L$ 's Financial performance over time

\subsection{Evaluating performance of PAL's advisory services from the demand-side perspective}

On the demand side we first analyse the profile of surveyed client dairy farms, including their sources of farm advice and information, and reflect on the extent to which their characteristics match or do not with design features of the model - mainly client-targeting criteria and the value proposition. We then evaluate how the clients implemented the advice and what changes in yield were seen on the farms.

\subsubsection{Characteristics of clients}

Seventeen client farms drawn from nine counties were sampled from the 205 MSFs that PAL had supported by the end of 2018 . Of the sampled farms, Nandi was the farthest from ( $300 \mathrm{~km})$ and Kiambu the nearest to $(50 \mathrm{~km})$ PAL's Nairobi hub office. Three of the 17 farms were owned by institutions: a catholic agricultural college, a catholic church farm and a private high school farm. While the 17 farms were sampled under the commercial segment, most had also received some of PAL's services under the KMDP (project segment) subsidy.

Table 17 summarises the profiles of the farms in terms of respondents, farm managers, owners and farm-related characteristics. Most respondents were hired farm managers, since owners live away from the farms. Most farm managers had served for three years or more at the time of interview. The fact that most farm owners could not be interviewed limited the scope of insights that this survey was able to draw. The mean age of farm managers was 34 years; the minimum and maximum were 24 and 45 years respectively. According to data provided about one of the farm co-owners (PAL's register of clients tends to capture two contacts/co-directors, and mainly spouses as applicable), most were aged between 46 and 60 years (mean age is 53.5 years), and most ( 8 out of 14) were female. All possessed post-secondary education.

Dairy farming is the main on-farm economic activity, implying a high level of specialisation in terms of family farming ventures. Most dairy farms were five years old or less. Average herd size was 61 dairy animals, with a minimum and maximum of 24 and 169 respectively. Average accessible land was 38 acres, with a maximum of 92 acres. Leasing land for fodder production was cited as common, 
indicating a growing engagement with the land rental market. The main milk market channels are diverse: direct supply to processors $(29.4 \%)$, via cooperatives $(17.6 \%)$, ATM operators $(17.6 \%)$, and retailing to sister institutions (17.6\%) (Table 17). High turnover and scarcity of skilled and non-skilled workers are the most cited labour availability challenges. In terms of dairy farm structures and other physical assets, all 17 farms report that they have invested in improved cow housing structures over the last three years. Other commonly cited assets invested in were related to fodder and feed processing ( $100 \%$ of farms), milking and milk-handling machinery/equipment ( $58.5 \%$ of farms), and fodder storage structures (52.9\% of farms).

Table 17: Profile of PAL's client farms sampled

\begin{tabular}{|c|c|c|c|}
\hline Class & Variable & Category & Per cent \\
\hline \multirow{4}{*}{$\begin{array}{l}\text { Profile of respondents } \\
(n=17)\end{array}$} & \multirow[t]{2}{*}{ Gender } & Male & 76.5 \\
\hline & & Female & 23.5 \\
\hline & \multirow[t]{2}{*}{ Role in the farm } & Hired manager & 70.6 \\
\hline & & Co-director/owner & 29.4 \\
\hline \multirow{10}{*}{$\begin{array}{l}\text { Profile of farm managers } \\
(n=17)\end{array}$} & \multirow{2}{*}{$\begin{array}{l}\text { Hired manager's experience in a } \\
\text { commercial dairy farm }\end{array}$} & No previous experience & 41.2 \\
\hline & & Had previous experience & 58.8 \\
\hline & \multirow{4}{*}{$\begin{array}{l}\text { Qualification of hired manager in } \\
\text { a relevant profession }\end{array}$} & Degree & 23.5 \\
\hline & & Diploma & 17.6 \\
\hline & & Certificate/Craft & 29.4 \\
\hline & & No relevant training & 29.4 \\
\hline & \multirow{4}{*}{$\begin{array}{l}\text { Years served in the farm as } \\
\text { manager }(n=12)\end{array}$} & 1 & 16.7 \\
\hline & & 2 & 25.0 \\
\hline & & 3 & 33.3 \\
\hline & & $4-6$ & 25.0 \\
\hline \multirow{8}{*}{$\begin{array}{l}\text { Profile of registered } \\
\text { owner or one co-owner } \\
\text { ( } n=14 \text { family farms) }\end{array}$} & \multirow[t]{4}{*}{ Age (years) } & $\leq 35$ years & 7.0 \\
\hline & & $36-45$ years & 0.0 \\
\hline & & $46-60$ years & 85.7 \\
\hline & & $\geq 61$ years & 7.0 \\
\hline & \multirow[t]{2}{*}{ Education level } & Post-secondary & 21.4 \\
\hline & & University & 78.6 \\
\hline & \multirow[t]{2}{*}{ Residence } & Owner and spouse live away & 92.9 \\
\hline & & Female spouse lives on-farm & 7.1 \\
\hline \multirow{15}{*}{$\begin{array}{l}\text { Profile of the farm } \\
(n=17)\end{array}$} & \multirow{3}{*}{$\begin{array}{l}\text { Years commercial dairy farm has } \\
\text { been established }\end{array}$} & $\leq 5$ years & 58.8 \\
\hline & & $6-9$ years & 5.9 \\
\hline & & $\geq 10$ years & 35.3 \\
\hline & \multirow[t]{4}{*}{ Main milk marketing channel } & Dairy processor & 29.4 \\
\hline & & Coop processor & 17.6 \\
\hline & & ATM operator/milk dispenser & 17.6 \\
\hline & & Sister institutions & 17.6 \\
\hline & \multirow[t]{5}{*}{ Accessible land (acres) } & $\leq 10$ & 23.5 \\
\hline & & $11-20$ & 11.8 \\
\hline & & $21-30$ & 23.5 \\
\hline & & $31-50$ & 11.8 \\
\hline & & $51-92$ & 29.4 \\
\hline & \multirow[t]{3}{*}{ Herd size $(n=16)$} & $21-50$ & 56.3 \\
\hline & & $51-99$ & 25.0 \\
\hline & & $\geq 100$ & 18.8 \\
\hline
\end{tabular}

\subsubsection{Main sources of dairy farming advice and information}

Besides PAL, other sources of dairy farming advice and information cited by respondents were peers, private veterinarians, input dealers, online sources, other independent private advisors and public vets (Figure 15). Farm owners interviewed cited scarcity of well-managed peers' farms to benchmark against as the main challenge they encounter with the peers' option. Public veterinarians were acknowledged for their role in disease surveillance and vaccinations, private advisors (mainly nutritionists) for ability to increase milk yield in a short period, and private veterinarians for ease of accessibility as they are locally based. Online sources were acknowledged in terms of ease of access, though the credibility of content was cited as a concern. 
The main delivery methods experienced were individualised, group-based training, print and online reference materials, exchange visits and field days, in that order. Most advice exchanges (55\%) were reported to be fee-based, and most (67\%) were embedded in the sale of tangible inputs. 'Free' advice had been received from sources such as Meru Dairy Union, online sources, mass media and PAL.

Regarding PAL's services, the 17 sampled farms reported they had accessed, on average, three advisory products. The most patronised were DFB, OFC and ADM. Some farms reported they had taken up some products more than once. When asked about the support they valued most, farm managers said ADM and OFC, as well as the support by PAL's advisors in convincing farm owners to make certain decisions. Referral by peers was the leading mechanism that farms found out about PAL. Other links were outreach by PAL advisors (during profiling of MSF farms), the farm managers networks, Facebook and referral by international Dutch organisations (such as NUFFIC).

All farms reported they had benefited from a post-product/service follow-up visit and input and service linkages facilitated by PAL. Most were satisfied (53\%) or very satisfied (29\%) with services. Two $(12 \%)$ were neutral and one $(6 \%)$ dissatisfied. Reasons cited for low satisfaction were poor workmanship on cow barn construction, tendency to collect farm data repeatedly with little feedback, tendency not to use local measurement tools and simple language, the fact that PAL did not operate its own practical dairy farm, and the observation that farm advice needs to be more customised to individual farm contexts (operationalising the 'ideal farm' concept).

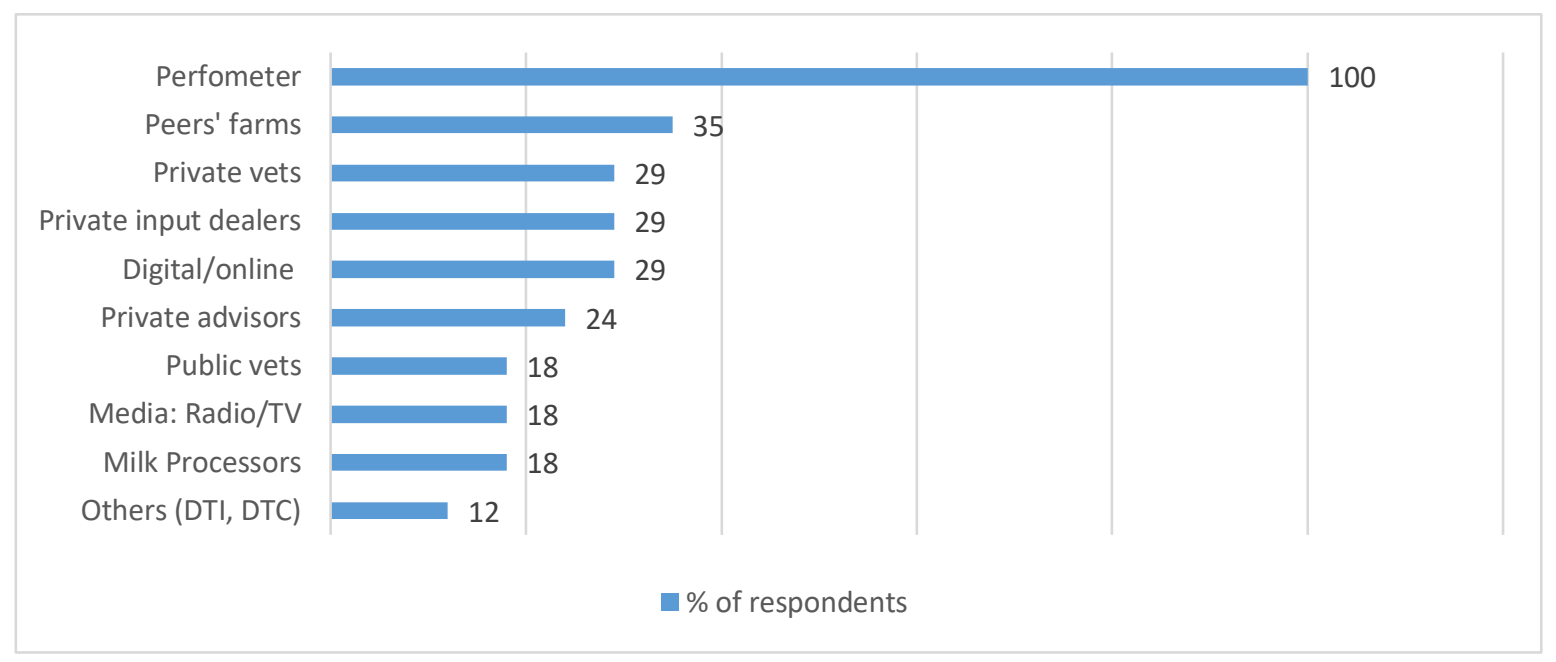

Figure 15: Main sources of dairy farming advice and information- PAL (=17)

Note: DTI: Dairy Training Institute-Kenya; DTC: Dairy Training Centre-Netherlands

\subsubsection{Implementation of advice}

Most respondents (94\%) reported an improvement in farm planning and management practices courtesy of PAL's advisory support. Most changes related to feeding, use of management tools and new husbandry practices (frequency of milking) (Figure 16). In addition, all farms report to have made some dairy farming investments as part of implementing the advice provided by PAL (Figure 17). All farms reported that they keep both manual and computer-aided records. Most kept records related to breeding, milk output and disposal, herd health, and finance. The main barriers cited to implementation of advice were limited availability of skilled labour with good work ethics, effects of drought and scarcity of water, and unstable and poor prices for raw fresh milk.

In the responses to the question 'What is the vision of the farm?', several themes emerged. Value addition/vertical integration is the most cited vision, followed by the desire to improve technical and/or economic performance of the farm. Others would like to transform their farm into a breeder's farm or a training farm, drive the succession strategy within the family, reduce herd size while increasing milk productivity, or venture into commercial mechanised fodder production. Interactions with PAL advisors were cited as a source for inspiring confidence in these dreams.

The encounter with PAL has made me change my mind, I had decided to do away with dairy farming before I met PAL. (Interview with farm owner 1)

When you make decisions based on data, you feel confident that you are focusing on the right thing. I want to increase the herd to 200 by 2022 (the year I am planning to retire from civil 
service); that is why you can see I am putting up a new cow barn. (Interview with farm owner 2)

PAL makes you see options; for now, we are confident with our strategy to rely on leasing land in Narok county for fodder production. (Interview with farm owner 3)

Feeding (feed planning, fodder production, making own ration)

Use of management tools (setting targets, keeping records, use SOPs etc)

Increasing frequency of milking

Cow comfort structures

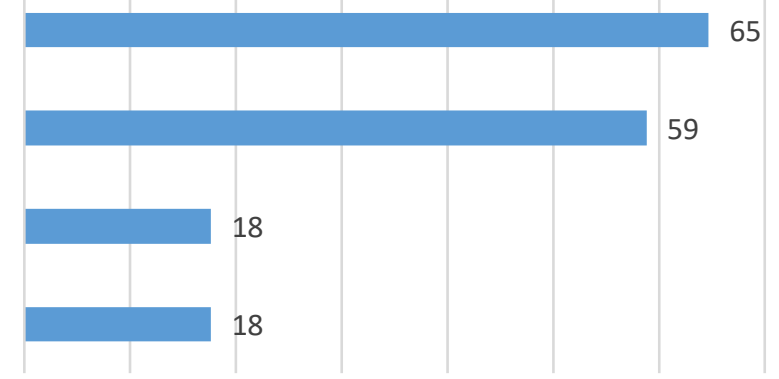

— $\%$ of respondents

Figure 16: Clients adoption of improved dairy farm practices - PAL $(n=17)$

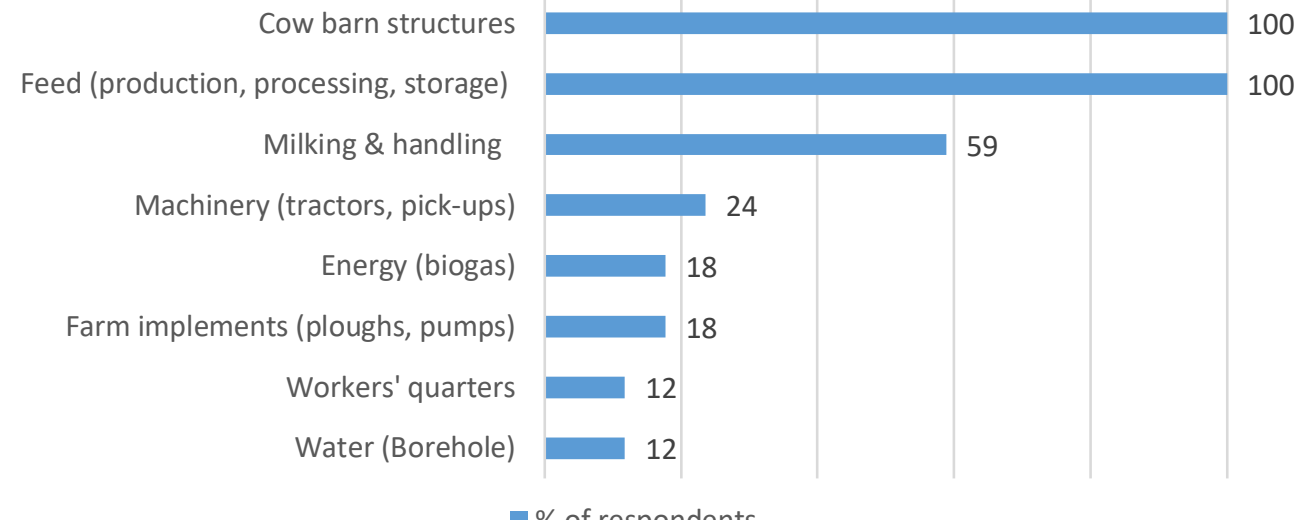

$\%$ of respondents

Figure 17: Types of investments made to improve the dairy farms - PAL $(n=17)$

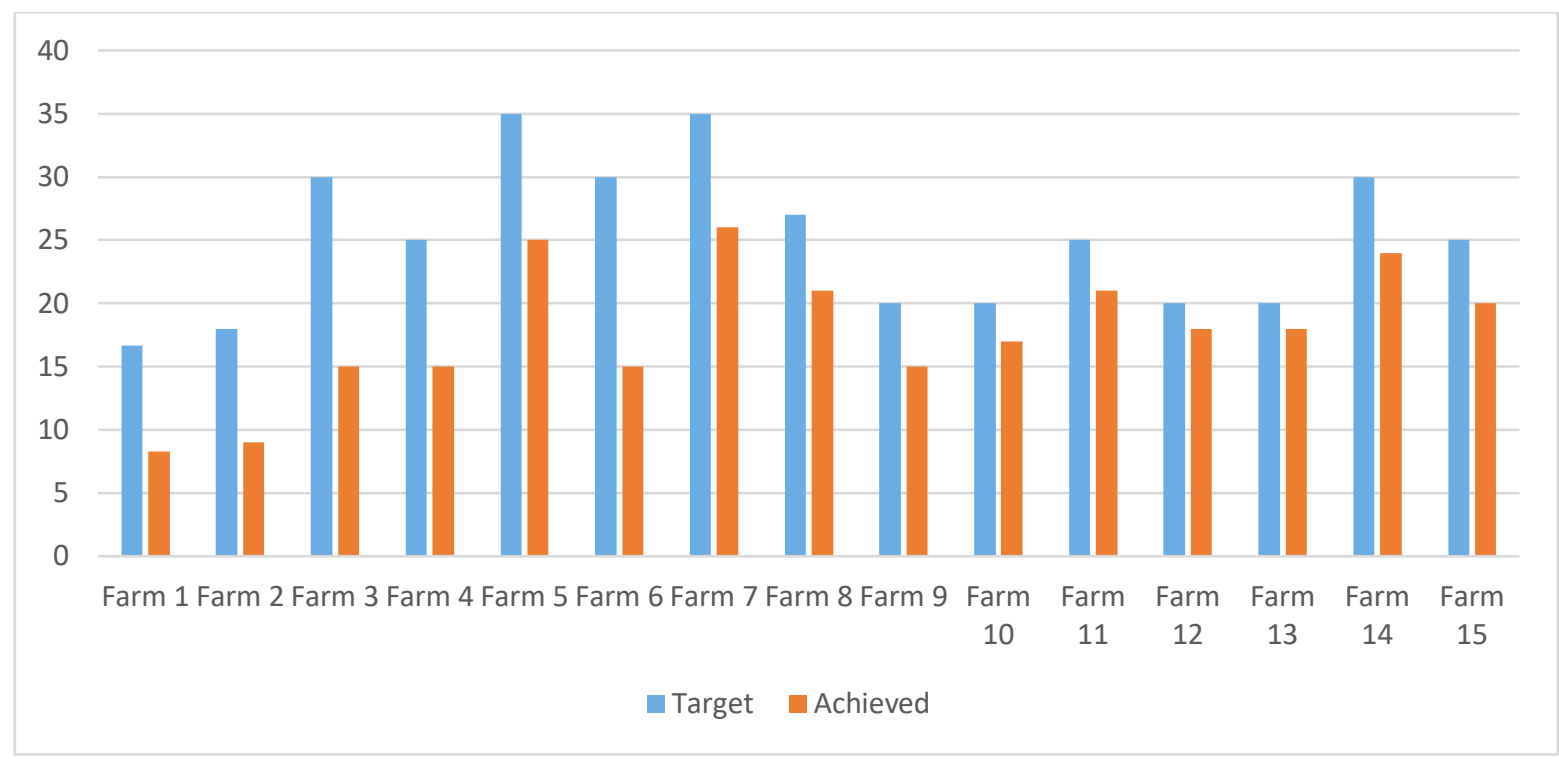

Figure 18: Performance in average daily liters per cow vs. own targets - PAL $(n=15)$ 


\subsubsection{Changes in yield and other farm-level outcomes}

Although self-reported milk yield data for 15 farms suggests that clients were yet to achieve their daily milk yield target per cow, the achieved average yields of 18 litres per cow (compared to a target of 25 litres) are double the national average (Figure 18). In addition, an independent assessment (Creemers, 2017) of eight client farms that had taken up DFB saw positive changes/improvements in all six of the farms that had implemented the DFB recommendations. However, this sample size is too small to guarantee generalisation of such findings.

\subsection{Conclusions and recommendations on the PAL model}

In this section we refer to the key questions guiding this assessment to draw conclusions and make recommendations.

\subsubsection{The design and operationalisation of the model}

PAL has been able to develop a suite of dairy advisory products targeting MSFs, giving them a unique niche as AEAS providers. These products have been found to be useful to the target clients, enabling the business to grow its client base (both commercial and project segments), improve revenue generation streams and, above all, increase turnover. Sustaining the professional attributes associated with its value proposition is emerging as one of the most critical areas that need attention, particularly as clients improve and aspire to further professionalise their dairy enterprises. Aligning advice with farm data and analytics, upgrading capacity of advisors, and sustaining linkages with knowledge systems from advanced dairy industries are some of the key pathways to professional, independent and internationally benchmarked dairy advisory services. Absence of key business KPIs for PAL in terms of service delivery and revenue generation also needs to be addressed. The value proposition for the project segment seems less articulated, yet the segment is predicted to remain an indispensable component of PAL's financing model.

\subsubsection{Relevance and effectiveness of advisory services to commercial segment clients}

Findings under section 4.4 underscore the relevance of PAL's services to the MSF segment. Attention areas to improve the relevance and effectiveness of services to clients relate to challenges to deepening the quality and professionalism of advisory services, especially as demand for specialised advice is projected to rise. The areas that need attention include:

i. poor record-keeping at farm level

ii. lack of historical technical and financial data and analytics at farm level

iii. the need to blend benchmarking against international standards with farm-specific contextual factors when defining and charting the overall farm improvement plan (operationalising the 'ideal farm' concept).

\subsubsection{Inclusiveness, financial sustainability and scaling}

We observe that PAL has made a strategic choice to target MSFs as a niche client segment and thus remains a model exclusively for smallholder dairy farmers, except under the project segment. We observe that while the model has grown and diversified its sources of revenue, the commercial AEAS segment is yet to take lead. In addition, the model's current business policy is currently against upscaling the commercial segment due to limited services delivery infrastructure. However, the model has proven its viability for scaling under certain conditions through its ability to attract donor start-up support, establish linkages with knowledge systems from advanced industries and identify and stimulate a potential MSF segment. 


\section{Case 4: New Kenya Cooperative Creameries' dairy advisory model}

\subsection{About the business}

New Kenya Cooperative Creameries (NKCC) Limited is one of the oldest and largest dairy processors in Kenya. It sources raw milk across the country from small-, medium- and large-scale dairy farms, either through individual or group-based supply contracts. From around 2010, NKCC has expanded its processing capacity from 850,000 to 1.5 million litres per day (NKCC, n.d.). NKCC has a network of 18 milk collection centres (MCCs) spread across the five clusters that supply the five processing plants, which are in the major milk sheds of Kenya. Kapsabet MCC, in Nandi county was the focus of this study.

The NKCC supply chain, like most dairy processors, relies on the dominant small-scale producers' segment. This poses huge challenges related to efficient production, collection, cooling, transportation and processing. These challenges are exacerbated by seasonal fluctuations, with high milk production in wet seasons that can result in a glut, and dry seasons being characterised by low production. This has led to stiff competition for raw milk among formal and informal market players. This happens in a climate of increased consumer demand that is driving investment in processing and emergent alternative milk-retailing outlets such as the ATM dispensers.

In response to these milk supply chain dynamics, NKCC decided to integrate delivery of dairy advisory services as part of its raw milk procurement strategy to boost and sustain milk intake through stronger relationships with suppliers. This was an improvement on the previous approach, which relied on the functions of a lean field services department reaching out to their supplier farms to mobilise milk supply. The field services team organised irregular farmer training, field days and meetings to gather feedback. During these meetings (around 2010/2011) farmers voiced their wish for NKCC to change tactic in its milk procurement strategies and develop a stronger relationship with suppliers (interview with NKCC extension team, Kapsabet MCC).

The Kapsabet MCC has a daily collection capacity of 100,000 litres of raw milk but operates at about $40 \%$ capacity on average. At the time of the study (March 2019), the MCC was at about $10 \%$ capacity (interview with Kapsabet MCC Manager).

\subsection{Design of the NKCC milk supply chain-embedded advisory model}

The interview with the NKCC extension team in Kapsabet and review of some business documents (NKCC, n.d.) provided details about the design and operationalisation features of the extension model. In 2012, NKCC hired a new manager to head the newly revamped Milk Procurement and Extension Services Department. The manager had extensive experience working in dairy development programmes and led the conceptualisation and testing of the extension services delivery model (Figure 19) that was rolled out in all 18 MCCs in 2014.

In the model, NKCC enters into a supply contract for milk with farmers/producer groups/cooperatives and offers to facilitate linkages to an array of inputs and services providers, in order to secure a reliable supply of high-quality raw milk. The model's package of services includes access to four types of products (outlined in Table 19). The model offers different value propositions to different actors:

i. For private providers of inputs and services, the model will stimulate a solid client base.

ii. For dairy advisors, the model will offer a launching pad for entrepreneurial graduates to establish a profession and business portfolio as private dairy advisors.

iii. For dairy groups/coops, the model will provide a mechanism for offering members advice.

iv. For dairy development NGOs and programmes, the model will provide an opportunity for partnerships to scale innovative dairy advisory models. 
v. For county governments, the model will provide opportunities for synergies in dairy services.

In each of the $18 \mathrm{MCCs}$, an Extension Committee is created that draws representatives from key value chain actors and enablers. A representative of the leading milk supplier within the MCC - often a dairy group/cooperative - chairs the committee. The committee hires an Extension Coordinator (secretary to the Extension Committee [EC]) and Extension Agents (EAs) who were later renamed Dairy Farm Assistants (DFAs). The DFAs are the links between NKCC and its long-term milk suppliers and services providers.

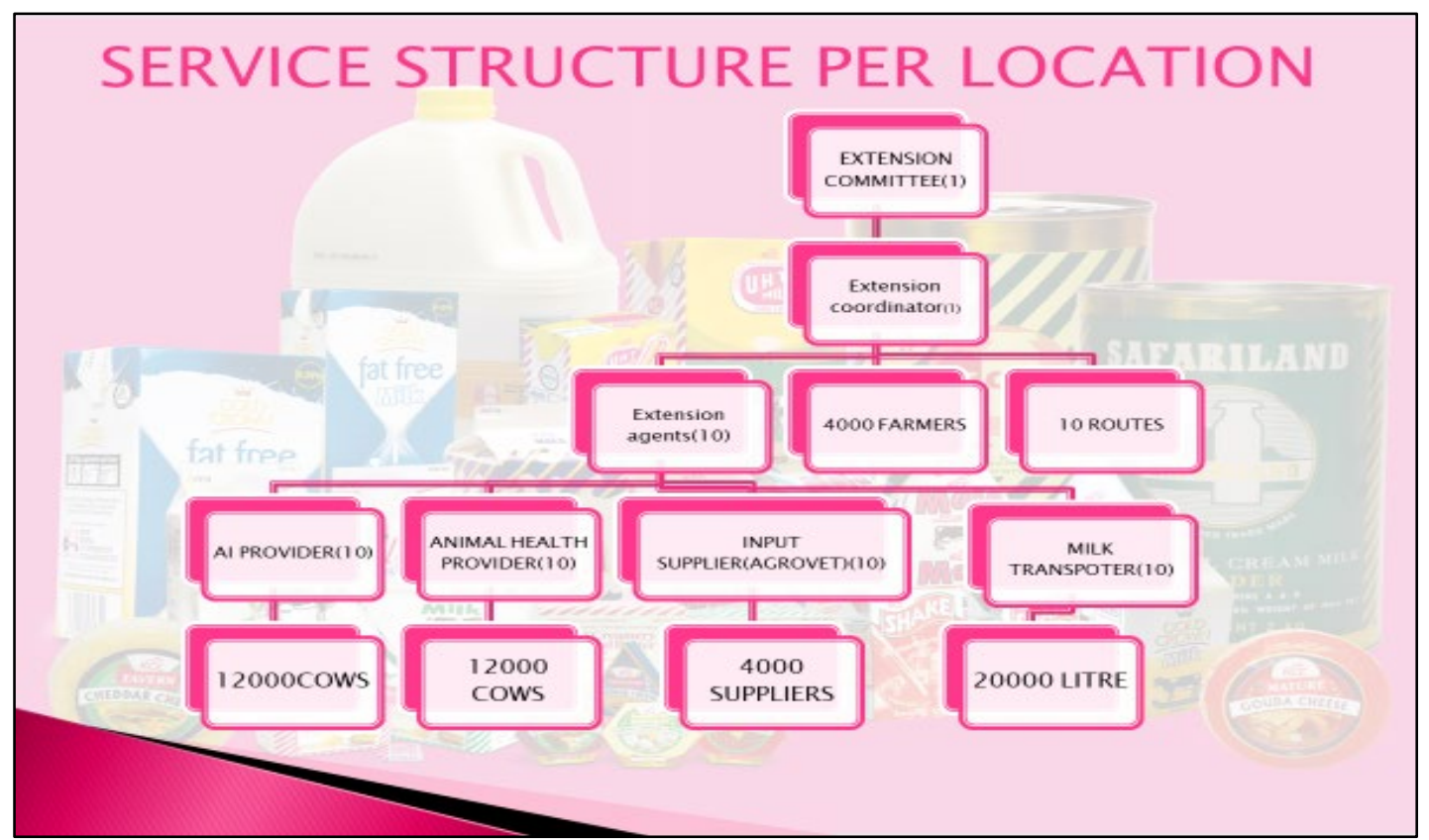

Figure 19: Conceptual illustration of NKCC extension model

Source: NKCC (n.d.)

\subsubsection{Client targeting, business development, costing and financing}

NKCC's milk procurement strategy envisions three types of suppliers of raw milk (NKCC, n.d.) as summarised in Table 18. All long-term suppliers are eligible to access the full package of extension and other services, while medium- and short-term suppliers are eligible to reduced service packages. Table 19 presents key operationalisation features of the model as observed in the Kapsabet MCC.

Table 18: Categorisation of NKCC milk suppliers

\begin{tabular}{lll}
\hline $\begin{array}{l}\text { Supplier } \\
\text { categories }\end{array}$ & Characterisation & Services eligibility \\
\hline Long term & $\begin{array}{l}\text { These supply a consistent } \\
\text { amount of milk despite } \\
\text { seasonal fluctuations in yields } \\
\text { and prices offered by NKCC }\end{array}$ & $\begin{array}{l}\text { Long-term supply contract ( } \geq 1 \text { year) } \\
\text { Complete support services package (Table 19) } \\
\text { Fixed price for one year, adjusted to average out } \\
\text { seasonality } \\
\text { Cattle registration and insurance } \\
\text { Prompt payment by the } 10^{\text {th }} \text { of every month }\end{array}$ \\
\hline term & $\begin{array}{l}\text { Seasonal suppliers reduce or } \\
\text { withdraw supply when NKCC }\end{array}$ & $\begin{array}{l}\text { Quarter-term contract ( } \leq 3 \text { months) } \\
\text { Access to minimum package of support services }\end{array}$ \\
& $\begin{array}{l}\text { producer prices decline. } \\
\text { Provide a plan to supply milk }\end{array}$ & $\begin{array}{l}\text { Six months' probation if they wish to be upgraded to long- } \\
\text { term conditions }\end{array}$ \\
& for three months to the & \\
\hline processor & Walk-in suppliers who are & No supply contracts but have supply numbers \\
& source of unplanned milk & Access to basic services (e.g. cooling facilities) \\
& supply & Minimum base milk price reflects supply and demand \\
\hline
\end{tabular}

Source: Adapted from NKCC (n.d.) and interviews with the team in Kapsabet MCC 
Table 19: NKCC service package, client targeting and business development aspects

\begin{tabular}{|c|c|c|}
\hline Services by type & $\begin{array}{l}\text { Client targeting, business development, } \\
\text { costing and financing }\end{array}$ & $\begin{array}{l}\text { Modifications observed } \\
\text { under Kapsabet MCC }\end{array}$ \\
\hline $\begin{array}{l}\text { Type 1: Milk collection, } \\
\text { transportation, and } \\
\text { cooling centre services }\end{array}$ & $\begin{array}{l}\text { 4,000 long-term suppliers per MCC. } \\
\text { Each MCC served by an average of } 10 \text { milk } \\
\text { transporters, targeting } 20,000 \\
\text { litres/MCC/day. } \\
\text { Milk must meet set standards, and prices are } \\
\text { subject to adjustment. } \\
\text { Long-term suppliers consent to a levy of } \\
\text { KES } 50 \text { cents/litre of milk to finance } \\
\text { extension. }\end{array}$ & $\begin{array}{l}\text { DFAs mandated to re-scout } \\
\text { and recruit high potential milk } \\
\text { suppliers. }\end{array}$ \\
\hline $\begin{array}{l}\text { Type 2: Extension } \\
\text { (farm visits) }\end{array}$ & $\begin{array}{l}\text { Each EA is assigned to } 400 \text { farmers and paid } \\
\text { on a commission basis. } \\
\text { Each EA to mobilise } 5 \text { litres/day/supplier } \\
\text { (=2000 litres/day/EA) } \\
\text { Each farmer is estimated to own } 3 \text { dairy cows } \\
\text { ( } 1200 \text { cows per EA) } \\
\text { On average } 10 \text { EAs per MCC }\end{array}$ & $\begin{array}{l}\text { EAs employed (salaried } \\
\text { KES } 7,000-10,000 \text { ) as DFAs. } \\
\text { DFAs assigned to support } 50 \\
\text { farms to increase milk from } 4 \\
\text { to } 12 \text { litres/cow. } \\
\text { Make } 1 \text { visit/week/farm. } \\
\text { On average } 80 \text { DFAs per MCC. }\end{array}$ \\
\hline $\begin{array}{l}\text { Type 3: Access to } \\
\text { knowledge exchange } \\
\text { events }\end{array}$ & $\begin{array}{l}\text { Exchange visits are financed by the } \\
\text { KES } 50 \text { cents/litre milk levy, while field days } \\
\text { are co-organised and co-financed with other } \\
\text { actors }\end{array}$ & $\begin{array}{l}\text { Decline in international } \\
\text { exchange visits due to decline } \\
\text { in funds for extension. }\end{array}$ \\
\hline $\begin{array}{l}\text { Type 4: Linkages for } \\
\text { inputs and other } \\
\text { services through the } \\
\text { ICT (AgriLife) platform } \\
\text { that would facilitate } \\
\text { credit mechanisms }\end{array}$ & $\begin{array}{l}\text { Platform to host economic data of key actors } \\
\text { and to enable financing (akin to a blockchain). } \\
\text { On average } 30 \text { providers per MCC. } \\
\text { DFAs tasked to promote and monitor } \\
\text { linkages. } \\
\text { Linkages through contracts and/or MoUs } \\
\text { Public livestock officers to regulate quality }\end{array}$ & $\begin{array}{l}\text { Inputs and services businesses } \\
\text { that are owned by the dairy } \\
\text { cooperatives/groups are } \\
\text { eligible to provide } \mathrm{AI}^{*}, \mathrm{AH}^{*}, \\
\mathrm{AV}^{*} \text { services on check-off } \\
\text { mechanisms. }\end{array}$ \\
\hline
\end{tabular}

Sources: Interviews with NKCC team in Kapsabet MCC and review of business documents (NKCC, n.d.)

* Note AI: Artificial Insemination; AH: Animal Health; AV: Agrovet stores

Interviews with the NKCC Kapsabet team and review of business documents (NKCC, n.d.) provided insights about the costing and financing arrangements. The model is designed to operate on a costrecovery approach through a voluntary levy, where consenting long-term milk suppliers are deducted KES 50 cents/litre of milk supplied. According to NKCC (n.d.), the per litre rate is based on a projection of 162 million litres of raw milk per year from 54,000 long-term suppliers across the 18 MCCs. This translates to an average daily supply of 8 litres per long-term supplier, 3,000 long-term suppliers per MCC and an extension kitty amounting to KES 4.5 million per year (375,000 per month at the MCC level). Other sources of financing have been limited; even NKCC does not contribute. The partnership between NKCC and Heifer Project International under the Kenya Market-led Dairy Supply Chain Project (KEMDAP) was the only major alternative source of financing leveraged at the time of this assessment. A standard budget template has been developed with 10 budget lines to guide ECs. The budget lines include activities such as local and international tours, salaries, EC meetings, supplier mobilisation activities, communication and mobility, participation in agricultural shows, committee allowances, farmer barazas, and training for other actors.

\subsubsection{Advisors' profiles, roles and deployment}

Extension agents (EAs) were like milk campaigners; the change of title to DFAs meant working closely with farmers to improve milk yields from an average of 4 to 12 litres per cow for the three most promising cows per farmer. (Interview with extension team member, Kapsabet MCC)

The entry requirements for advisors are a certificate or diploma (for DFAs) and degree (for Extension Coordinators) in an agriculture/livestock field. Previous experience is desirable but not mandatory other than for the Extension Coordinators. NKCC managers provide technical and administrative support. The local livestock and veterinary officers from the local county government are expected to provide oversight and backstopping. The profile of DFAs would have been different had the model continued with the original idea of EAs as either input providers embedding dairy advisory services in 
sale of inputs or as brokers of inputs and services and therefore paid on commission basis. Table 20 offers a summary of the profile of advisors in Kapsabet MCC.

According to interviews with the NKCC extension team in Kapsabet, the model anticipates a mixed delivery approach for dairy advisory services, involving an in-house team of DFAs and leveraging on other providers drawn from private dairy input and support services actors and local public livestock and veterinary officers. The DFAs are expected to play different roles, as well as those directly related to providing dairy advice and training events (Table 21). The Extension Coordinator provides technical backstopping to the DFAs and acts as the managerial/administrative link to the EC and NKCC managers. Generally, DFAs view these additional roles as complementary to the model's overall value proposition. In terms of mobility and field facilitation, the norm was to provide a daily field allowance (of KES 600 per day) to cater for public transport, meals and telephone credit ('airtime') during farm visits. Use of smartphones to digitise data was envisioned. Capacity development strategies for the advisors include in-house training organised by NKCC; interactions with the local public livestock and veterinary officers, training and research institutions (e.g. KALRO, Egerton); and events organised by NGOs (TechnoServe, Heifer/KEMDAP, SNV) and input suppliers. Working closely with the members of the EC or cooperative committees is also a mechanism for onboarding new DFAs. Also, the committee members are relied on in communicating non-technical messages to farmers.

Table 20: $\quad$ Profile of advisors in NKCC Kapsabet MCC

\begin{tabular}{|c|c|c|c|c|}
\hline $\begin{array}{l}\text { Professional } \\
\text { qualification }\end{array}$ & $\begin{array}{l}\text { Areas of } \\
\text { study }\end{array}$ & $\begin{array}{l}\text { Training } \\
\text { institutions }\end{array}$ & $\begin{array}{l}\text { Summary of previous } \\
\text { experiences }\end{array}$ & $\begin{array}{l}\text { Age, gender, } \\
\text { experience with } \\
\text { the model }\end{array}$ \\
\hline $\begin{array}{l}\text { Diplomas and } \\
\text { certificates } \\
\text { (DFAs) } \\
\text { Degree } \\
\text { (Extension } \\
\text { Coordinator) }\end{array}$ & $\begin{array}{l}\text { General } \\
\text { agriculture } \\
\text { Agribusiness } \\
\text { management } \\
\text { Dairy } \\
\text { technology }\end{array}$ & $\begin{array}{l}\text { - Kaiboi and } \\
\text { O'l Lessos } \\
\text { - technical } \\
\text { training } \\
\text { institutes in } \\
\text { Nandi (TVETs) } \\
\text { - Egerton } \\
\text { University }\end{array}$ & $\begin{array}{l}\text { - Most are young without } \\
\text { previous experience } \\
\text { - One NKCC milk clerk was } \\
\text { promoted after completing a } \\
\text { certificate in general } \\
\text { agriculture } \\
\text { - Extension Coordinator had } \\
\text { worked as a milk quality officer } \\
\text { for three years in a dairy } \\
\text { cooperative supported by the } \\
\text { East Africa Dairy Development } \\
\text { programme }\end{array}$ & $\begin{array}{l}\text { - All (five) are } \\
\text { locals } \\
\text { - Most (60\%) are } \\
\text { males } \\
\text { - Age: } 26-52 \\
\text { years } \\
\text { - Most joined at } \\
\text { inception of the } \\
\text { model in } \\
2013 / 2014\end{array}$ \\
\hline
\end{tabular}

Table 21: Main types of roles played by DFAs - NKCC

\begin{tabular}{ll}
\hline Main roles by type & Activities \\
\hline Provide dairy advice and training & $\begin{array}{l}\text { Weekly farm visits, co-organise group training, field days and exchange } \\
\text { tours, respond to hotline calls from assigned farms }\end{array}$ \\
\hline Mobilise milk supply & $\begin{array}{l}\text { Scout } 50 \text { most promising farms in milk supply, scrutinise milk supply } \\
\text { records at MCC or coop, organise barazas and door-to-door milk } \\
\text { campaigns }\end{array}$ \\
\hline Mobilise groups & Organise assigned farmers into dairy interest groups \\
\hline Link farmers to input providers & $\begin{array}{l}\text { Monitor existing linkages } \\
\text { Share farm intelligence with services providers } \\
\text { Co-organise joint farmer events with service providers }\end{array}$ \\
\hline Administrative and management & $\begin{array}{l}\text { Collect farm profile data, cow registration data, and monitoring and } \\
\text { progress data per provided templates; fill in extension delivery data } \\
\text { and reports }\end{array}$ \\
\hline
\end{tabular}




\subsubsection{Key partnerships and modifications on the model}

The model has sought to mobilise partnerships with diverse actors involved in providing dairy input and support services as summarised in Table 22 below. Changes in advisor roles and ratio to farmers are the most prominent modifications to the model. The EA/DFA:farmer ratio has changed from 1:400 to 1:50. Also, the KEMDAP project in Kabiyet Dairies (Cooperative)-the leading milk supplier to Kapsabet MCC-adapted a ratio of $1: 100$. KPIs for DFAs were originally related to volume of milk brokered, but this was later broadened to include farm-level outcomes and functioning of the network of linkages facilitated.

Table 22: Types of partnerships envisaged under NKCC model

\begin{tabular}{ll}
\hline \multicolumn{1}{c}{ Type of partners } & Areas of collaborations \\
\hline $\begin{array}{l}\text { Dairy input dealers and } \\
\text { suppliers }\end{array}$ & $\begin{array}{l}\text { Linkages for easing access to dairy inputs and services } \\
\text { Sources of embedded dairy advice and information }\end{array}$ \\
\hline Dairy groups and & As primary aggregators of milk supplied to the processor \\
cooperatives & To enhance mobilisation of dairy producers and coordination for services \\
\hline $\begin{array}{l}\text { Dairy development } \\
\text { programmes and NGOs }\end{array}$ & $\begin{array}{l}\text { Sources of additional financing for advisory services (Heifer International) } \\
\text { Supplementary sources of dairy advisory and support services (e.g. } \\
\text { TechnoServe, SNV/KMDP) } \\
\text { Capacity-building of DFAs and developing content and reference materials } \\
\text { (Heifer International) }\end{array}$ \\
\hline $\begin{array}{l}\text { Insurance and financial } \\
\text { services providers consenting Linkages for easing financing both to farmers and local input dealers } \\
\text { to participate in the AgriLife } \\
\text { platform }\end{array}$ & $\begin{array}{l}\text { (commercial banks: KCB, NBK; microfinance: Rafiki); and savings and credit } \\
\text { cooperatives/financial services associations }\end{array}$ \\
\hline County governments & $\begin{array}{l}\text { Linkages for provision of dairy advisory services and farmer training } \\
\text { Providing quality assurance on advisory services and inputs } \\
\text { Capacity-building of DFAs and developing content and reference materials }\end{array}$ \\
\hline
\end{tabular}

\subsection{Evaluating performance of the NKCC model from the supply-side perspective}

This section presents findings on the performance of the model from the supply-side perspective, where we examined i) uptake of AEAS and complementary services, and ii) financing and benefits of AEAS to the firm.

\subsubsection{Uptake of dairy advisory and complementary services}

Secondary data accessed for Kapsabet MCC and interviews with the extension team provide insights about the performance of the model in delivering dairy advisory services. By the time of the field survey (March 2019), the number of DFAs had been downsized from 10 (who were serving in the last half of 2018) to six. However, the optimal target should have been 80 DFAs, according to the modifications made to the model. Of the six DFAs, four were serving under Kabiyet Dairies, where further modifications to the model had been introduced under the KEMDAP project. By the last half of 2018 , the model was served by $8 \%$ of projected DFAs and covered $300(8 \%)$ of the 4,000 targeted long-term suppliers. The team interviewed indicated that the frequency of farm visits had declined tremendously (to $30 \%$ ) following lack of funds to finance field mobility, and that a pattern to serve farms supplying larger volumes of milk had emerged spontaneously (Figure 20). Other extension services activities had been scaled down, such as international exchange visits.

Performance data accessed shows progress was made through the newKCC model in linking milk suppliers with providers of complementary dairy inputs and services (Figure 20). However, interviews with the extension team revealed that the performance of such linkages was mixed. The credit (checkoff) arrangements initiated with six agrovets were reported to have been disabled in 2017 after three years of operation. The main reasons cited were delays in NKCC remitting payments to service providers (meant to be by the $10^{\text {th }}$ of every month), and that most providers were concentrated 
around Kapsabet town and suburbs and did not have a deep reach into the villages where a significant number of farmers were. The credit (check-off) system is, however, reported to have worked well under dairy groups/cooperatives that operate their own in-house agrovet businesses. It was also anticipated that most of the DFAs would be running dairy inputs and services provision businesses but attracting DFAs with such a profile proved difficult. Another factor that was noted to have hindered linkages is the delay in launching the Agrilife business platform and more importantly the integrated management information system that was meant to enable the platform (akin to a blockchain). Some of the unique services anticipated under the Agrilife platform were cow registration and livestock insurance services.

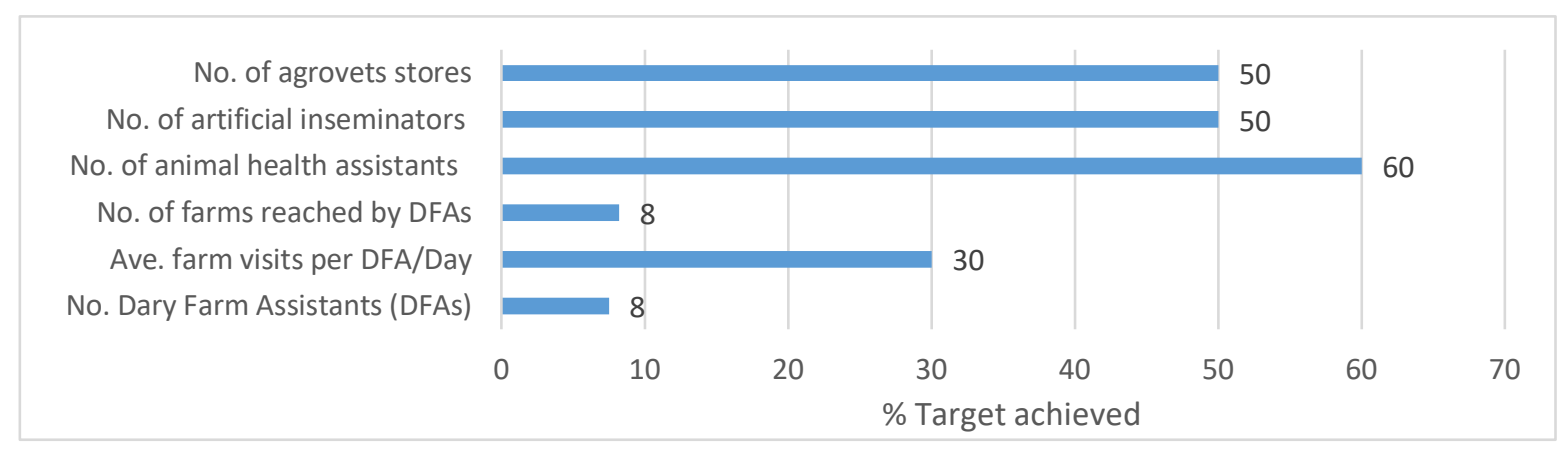

Figure 20: Performance on linkages with inputs and services by end of 2018- NKCC Kapsabet

\subsubsection{Financing of AEAS and benefits of AEAS to NKCC}

According to snapshot performance data accessed, all KPIs for consistent supply of raw milk had experienced frequent changes and generally decreased by the time of this assessment (Table 23). This implies that progress towards achieving the overall value proposition for the firm proved elusive. According to extension team members interviewed at Kapsabet MCC, the model performed better in the initial years (2014-2016) and started under-performing from 2017 onwards.

I remember we were doing well in 2014 and 2015 when we managed on average KES 2 million per year from the extension levy ... there was a month we got KES 750,000 from the milk levy ... last year (2018) the levy netted only KES 700,000 ... and the lowest month I have seen is in this year (2019) when we got KES 40,000. (Interview with extension team member, Kapsabet MCC)

Table 23: Performance in milk intake by volume and number of suppliers - NKCC Kapsabet MCC

\begin{tabular}{lcccc}
\hline Period & \multicolumn{2}{c}{ Average daily milk intake (litres) } & \multicolumn{2}{c}{ No. of long-term milk suppliers } \\
\cline { 2 - 5 } & Target & \% achievement & Target & \% achievement \\
\hline Nov 2016 & 12,810 & $118 \%$ & 2,562 & $85.0 \%$ \\
Sept 2017 & 25,000 & $48 \%$ & 5,000 & $14.6 \%$ \\
Feb 2018 & 25,000 & $9 \%$ & 5,000 & $5.1 \%$ \\
\hline
\end{tabular}

Advisors are the most expensive resources in the model, which needs to cover their salaries and field mobility expenses. Indeed, field mobility expenses seem to be higher than salaries. With the current low advisor:farmer ratio of 1:50, each long-term milk supplier needs to deliver on average at least 25 litres per day in order to recover the full costs of their respective DFA (Table 24). This implies that the model might not be suitable for small-scale dairy farmers who cannot raise a marketable volume of 25 litres per day. Alternatively, a higher DFA:farmer ratio and lower frequency of contact/farm visits may be a remedy if the objective is to target small-scale farms. Other challenges associated with low milk intake were weak milk collection and transportation strategies (some milk collection routes had been discontinued by the time of this assessment, leaving suppliers stranded), and inability of NKCC to sustain attractive prices and related incentives.

Our work is difficult. You can do your best and get good results at the farm level, including increases in milk yield ... but then NKCC slashes the prices of raw milk and your farmers decide to look for other market outlets. (Interview with DFA, Kapsabet MCC) 
Table 24: Advisor costs vs. milk intake required to meet them - NKCC Kapsabet MCC

\begin{tabular}{lllll}
\hline Advisor type & $\begin{array}{l}\text { Total monthly } \\
\text { costs (TMC) } \\
\text { KES }\end{array}$ & $\begin{array}{l}\text { Field } \\
\text { mobility } \\
\text { costs as } \\
\text { \% of TMC }\end{array}$ & $\begin{array}{l}\text { Milk from long-term } \\
\text { suppliers required to meet } \\
\text { TMC of one advisor (kg) }\end{array}$ & $\begin{array}{l}\text { Av. daily milk intake } \\
\text { per long-term } \\
\text { supplier to meet } \\
\text { advisor costs (Its) }\end{array}$ \\
\cline { 1 - 2 } DFA & $19,000-22,000$ & $63-55 \%$ & $38,000-44,000$ & $25-29$ \\
\cline { 1 - 2 } $\begin{array}{l}\text { Extension } \\
\text { Coordinator }\end{array}$ & $27,000-32,000$ & $44-38 \%$ & & \\
\hline
\end{tabular}

\subsection{Evaluating performance of the NKCC dairy advisory model from the demand-side perspective}

On the demand side we characterise the farmer clients $(n=46)$, including their sources of farm advice and information, and reflect on the extent to which their characteristics match or do not with design features of the model - mainly client-targeting criteria and the value proposition (i.e. relevance). We then evaluate how the farmers implemented the advice, and what changes in yield were seen on the farms.

\subsubsection{Characteristics of clients}

Forty-six long-term milk suppliers were sampled (out of the 300) drawn from milk collection routes served by the six DFAs that were active by the time of the assessment. They were drawn from Chesumei (59\%), Emgwen (28\%) and Mosop (13\%) subcounties. The majority (56\%) were under group supply contracts. Youth and women suppliers were $13 \%$ and $22 \%$ respectively. The mean age of suppliers was 53 years, with a minimum and maximum of 25 and 78 years. Most clients (59.6\%) have post-primary education (Table 25).

The level of diversification of households' economic activities (on-farm and off-farm) seems to be high. All suppliers engage in on-farm activities, and $61 \%$ in off-farm activities. This seems higher than the $40 \%$ off-farm engagement reported in a recent study in the same area by van der Lee et al. (2018). Under on-farm activities, dairy and tea were the most common commercial commodities cited. This appears to be a high level of specialisation under on-farm economic activities. Mean years in dairy farming was 23.

Most suppliers (56.5\%) had access to 3-10 acres of land and a dairy herd of five animals or fewer $(56.5 \%)$. At the time of the assessment, $42 \%$ of the herd was estimated to be lactating. Minimum and maximum accessible land was 1 and 80 acres respectively, with an average of 11.4 acres. Inheritance $(96 \%)$ is the leading land access method, followed by purchase $(65 \%)$. About $20 \%$ engaged in the land rental market. According to the County Government of Nandi official statistics, most people (80\%) have titles to their land (CGN, 2018).

\subsubsection{Main sources of farming advice and information}

Results in Figure 21 indicate that for the sampled farmers NKCC is an important source of advice and information regarding commercial dairy farming, followed by media (radio and TV), then peers. The main extension and advisory delivery methods experienced were farm visits, field days, group-based training events, and mass media. While there is a levy of KES 50 cents/litre that NKCC deducts for the purpose of extension, the respondents tend to perceive the services as free, indicating some level of information asymmetry. Almost half (43\%) of the respondents reported that they have smart phones, and $37 \%$ have used their phones to access dairy farming advice and information.

When asked what they dislike about the identified sources of advice, $45.7 \%$ of respondents who gave neutral, dissatisfied and very dissatisfied ratings cited the attributes summarised in Table 26. 
Table 25: Profile of suppliers surveyed $(n=46)-$ NKCC Kapsabet

\begin{tabular}{|c|c|c|c|}
\hline Class & Variable & Category & Per cent \\
\hline \multirow{12}{*}{$\begin{array}{l}\text { Profile of respondents/ } \\
\text { clients }(n=46)\end{array}$} & \multirow[t]{2}{*}{ Gender } & Male & 78.0 \\
\hline & & Female & 22.0 \\
\hline & \multirow[t]{4}{*}{ Age (years) } & $\leq 35$ years & 13.0 \\
\hline & & $36-45$ years & 15.0 \\
\hline & & $46-60$ years & 43.0 \\
\hline & & $\geq 61$ years & 28.0 \\
\hline & \multirow[t]{4}{*}{ Education level } & No formal & 4.4 \\
\hline & & Primary & 37.0 \\
\hline & & Secondary & 21.7 \\
\hline & & Post-secondary & 37.9 \\
\hline & \multirow[t]{2}{*}{ Supply contract type } & Individual & 43.0 \\
\hline & & $\begin{array}{l}\text { Group/coop- } \\
\text { based }\end{array}$ & 56.0 \\
\hline \multirow{17}{*}{$\begin{array}{l}\text { Economic activities and } \\
\text { resources for clients' } \\
\text { households }(n=46)\end{array}$} & \multirow[t]{3}{*}{ Main sources of income } & On-farm & 100.0 \\
\hline & & Off-farm & 61.0 \\
\hline & & Remittances & 4.4 \\
\hline & \multirow[t]{2}{*}{ Top commercial commodities } & Dairy & 100.0 \\
\hline & & Tea & 52.0 \\
\hline & Member of a farmer group & Yes & 85.0 \\
\hline & \multirow[t]{4}{*}{ Dairy cattle herd size } & $<5$ & 56.5 \\
\hline & & $6-10$ & 15.2 \\
\hline & & $11-20$ & 21.7 \\
\hline & & $>20$ & 6.5 \\
\hline & \multirow[t]{4}{*}{ Accessible land } & $<3$ acres & 13.0 \\
\hline & & $3-10$ acres & 56.5 \\
\hline & & $11-20$ acres & 19.6 \\
\hline & & $>20$ acres & 10.9 \\
\hline & \multirow[t]{3}{*}{ Land access method } & Inherited & 95.7 \\
\hline & & Purchased & 65.2 \\
\hline & & Leased & 19.6 \\
\hline
\end{tabular}

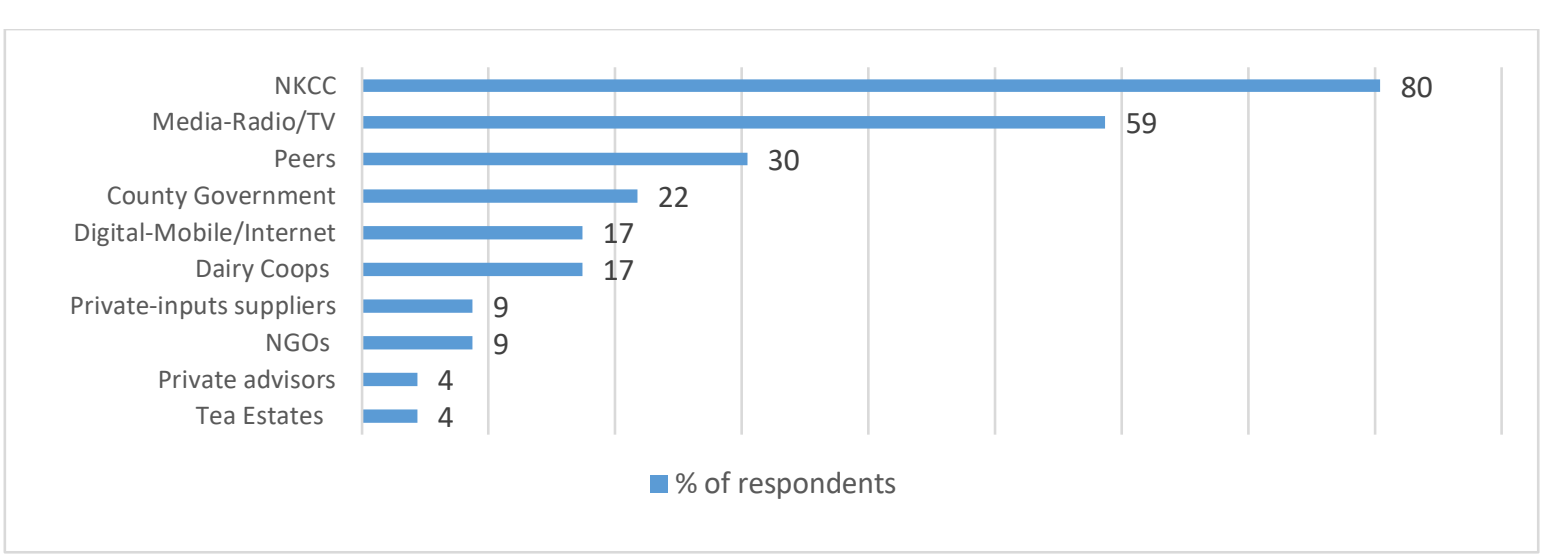

Figure 21: Farmers main sources of dairy advice and information- NKCC Kapsabet $(n=46)$

Table 26: Negative attributes about key providers of dairy advice - NKCC Kapsabet

\begin{tabular}{|c|c|c|}
\hline County government & Media and digital platforms & NKCC \\
\hline $\begin{array}{ll}- & \text { No longer available } \\
\text { - } & \text { Irregular in } \\
\text { - } & \text { provision } \\
\text { Repetitive } \\
\text { messaging }\end{array}$ & $\begin{array}{ll}- & \text { Problems with clarity of message } \\
\text { - } & \text { Fear of exaggeration, impractical } \\
& \text { information } \\
\text { - } & \text { Inability to verify information }\end{array}$ & $\begin{array}{ll}- & \text { Disconnected messages - } \\
\text { promoting increased production } \\
\text { yet reducing prices for raw milk } \\
\text { - Termination of services without } \\
\text { notice }\end{array}$ \\
\hline
\end{tabular}


The individual suppliers interviewed cited several reasons for signing up to NKCC's long-term milk supply programme and dairy advisory services. They include historical sentiments of their longstanding relationship with the processor, albeit punctuated by highs and lows; NKCC's association with the state (as a state corporation) provides suppliers with confidence that, despite any bad experiences, dues are eventually paid. Other reasons are proximity to NKCC's milk collection and cooling facilities, consolidated payments, linkages with financial services and input providers, and guarantee to take all milk delivered. As one of the largest processors with extensive MCC infrastructure, NKCC is a leading off-taker of milk that suppliers can turn to irregularly depending on market conditions.

According to the survey data, the main weakness associated with NKCC's dairy advisory services was the observed decline in frequency of farm visits, and it was felt that group-based training events accommodated too many participants to meet individuals' specific needs. For field days, low frequency and distance to venue were the main challenges cited, and there was a perceived lack of fairness in selecting participants for planned exchange visits. More cooperative-owned agrovet stores were wanted to improve access to quality inputs and favourable prices and incentives (e.g. bonus payments) for raw milk supplied. When asked about the qualities of a good DFA, most respondents identify both technical and functional attributes, such as being knowledgeable about dairy science and able to relate to farmers.

According to respondents, NKCC extension services have contributed positively to farmers working together $(67 \%)$ and to linking growers with other agribusiness partners (67\%). Collective effects have been achieved mainly through group-based knowledge exchange events, such as field days, tours, training and dairy groups. Most agribusiness partners linked are input dealers and financial actors such as SACCOs and banks, and the mechanisms for linking are collaborative events (field days) and credit (check-off) arrangements. Most respondents (93\%) feel that service delivery does not directly discriminate against men or women.

\subsubsection{Implementation of advice}

Most respondents report having adopted new dairy farm practices as a result of advice they have accessed through NKCC's extension model. As summarised in Figure 22, most practices relate to fodder and feeding, shifting from free range or zero to semi-zero grazing, record-keeping, deworming and spraying, and use of AI services. Reasons commonly cited as hindering adoption of improved practices are cost and labour implications, dependence on rainfall for fodder production, declining milk prices, low proximity of well-stocked stores, incidents of drought and outbreak of diseases.

Most respondents reveal that their future plans are to improve the technical performance of the dairy enterprise through increasing herd size, investing in improved physical assets (e.g. cow barns, fodder storage, fodder-processing equipment), improving husbandry practices (fodder planning, hay- and silage-making, own fodder production), improving breeds and reproduction management for better yields, and improving yields per cow. A few cite economic aspects such as diversifying the enterprise, monitoring trends in milk price and acting accordingly, paying attention to record-keeping and other non-milk dairy revenue streams (e.g. sale of heifers), and reducing herd size while increasing milk yields.

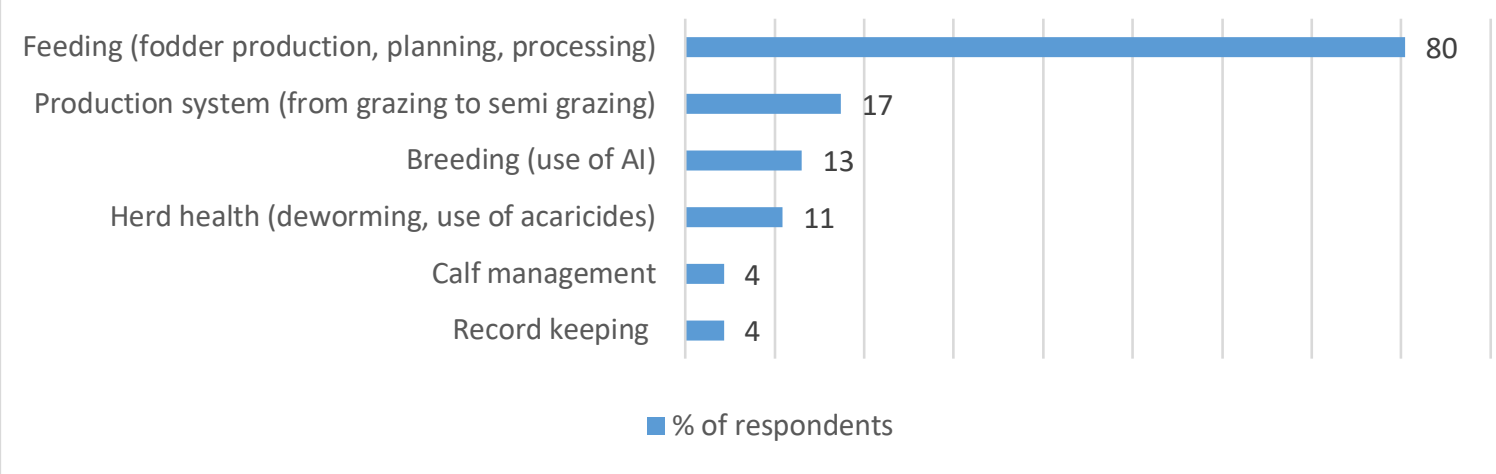

Figure 22: Percentage of suppliers adopting improved dairy practices - NKCC Kapsabet $(n=46)$ 


\subsubsection{Changes in milk yield}

The NKCC AEAS model recommends average milk yield of 12 liters per day per cow, and thus set this as the target to be achieved by their suppliers. Although from interviews we found that individual farmers seem to have set their own targets based on their own circumstances. The baseline reference point used to arrive at the target was the national average of five to eight liters per cow (nKCC, nd).

The survey data that was captured $(n=31)$ shows that majority $(74 \%)$ of suppliers had not attained the milk yield improvement target as recommended under NKCC's AEAS model (figure 23). The average yield reported for the best performing cow during the time of the study was found to be 9 litre \cow, although the minimum reported was as low as 4 litre per day \cow, while the maximum was 30 litres per day \cow). These findings suggest a marked diversity among suppliers in terms of milk productivity targets and performance. It was reported that the region had experienced drought that had adversely affected access to feed for the cows and affected production. Whereas there is a carder performing above the recommended milk productivity targets, majority seem to belong a category struggling to attain reasonable production improvements.

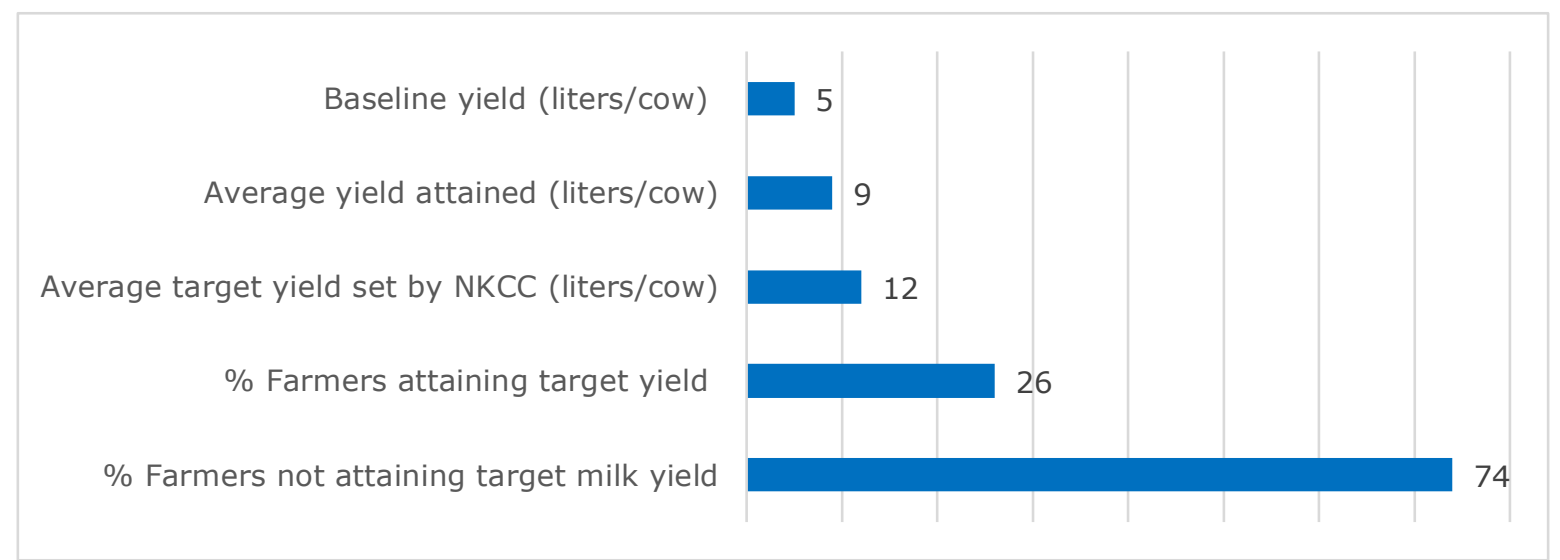

Figure 23: Farmers attainment of milk yield targets - NKCC Kapsabet $(n=31)$

\subsection{Conclusions and recommendations}

In this section we refer to the key questions guiding this assessment to draw conclusions and identify attention areas/recommendations.

\subsubsection{Design and operationalisation of the model}

The model's value proposition (VP) is considered quite ambitious and in line with the broadened expectations that AEAS will target not only farmers but also other actors that are key for the effectiveness of AEAS - such as dairy groups, an array of private inputs and service providers, and public players; in that sense, it is an ecosystem-level VP. The VP for NKCC (as the focal actor in the ecosystem) is to improve milk volume, quality and consistency of supply to its MCCs. To the farmer client, the VP is to improve milk productivity and loyalty to supply NKCC as the off-taker of choice. The model seeks to address farmer clients' needs for milk production knowledge, market access and linkages to other dairy production support inputs and services.

In terms of design and implementation, this assessment concludes the following.

i. Considerable efforts have been expended to roll out the model, with significant field-informed modifications and the promising results realised in 2014-2016.

ii. Key design oversights seem to have undermined the effectiveness of the model, such as weaknesses in costing and financing analysis; weakly defined criteria for long-term suppliers; and the decision to roll out without piloting in a few promising MCCs to learn and build capacity, confidence and buy-in within NKCC and with clients.

iii. Additionally, some key critical success factors (incentives for the model) that are relatively within NKCC's control seem not to have attracted adequate attention during implementation, such as milk prices offered, milk collection and transportation strategies, prompt payments to 
input dealers offering check-off to clients, and subjecting adjustments to a system-wide scenario analysis (e.g. shifts from EAs to DFAs, change from commission-based to salarybased remuneration, and changes in advisor ratio).

\subsubsection{Relevance and effectiveness of extension services to milk suppliers}

The survey findings described in section 5.4 underscore the role of dairy in the livelihood strategies of the farming community in Nandi. Thus, an increase in milk productivity provides significant scope to improve economic returns (alongside capturing better market conditions) for dairy farmers. By embedding dairy advisory services as part of securing milk supply, the NKCC model is well contextualised. Linking these services to addressing key farm-level constraints and supporting good farm practices (solutions) to improve milk productivity seem to be commonly shared goal. Under such conditions what matters is effectiveness in the implementation of the model. From a delivery approach perspective, the NKCC model blends advisory methods of individualised farm visits and group-based activities (training events, field days, local and international tours). However, areas of weakness observed were limited use of farm data and analytics to improve decision support. Also, advisors have basic qualifications and limited scope for specialisation. From a financial perspective, the sustainability of advisory services faces real threats following a decline in milk intake at NKCC in Kapsabet, which has led to low outreach and unreliable delivery.

\subsubsection{Inclusiveness, financial sustainability and scalability}

The model accommodates individual milk producers of various scales if they can manage a daily supply of 5 litres of milk on a long-term basis. The model does not explicitly target youth and women as milk producers, and most clients are predominantly male and aged 46 years and above. Further, we observe that due to resources constraints, advisors tend to favour larger milk suppliers.

As observed in the Kapsabet MCC case, financing the model faces challenges related to revenue collection through levying of supplies but with gaps in accountability of how funds are allocated and disbursed. Relatedly, loyalty of their supplies is affected by unstable raw milk prices and linkages to dairy inputs and support services. Decline in milk intake has led to low outreach and unreliable delivery. Overall, the scalability of the model is contingent on addressing these critical success factors that are largely within the control of the processor, such as those highlighted in part iii of 5.5.1 above. 


\section{Synthesis of the case studies}

This section presents a concluding cross-case analysis of the four case studies, reflecting on commonalities, differences and trends in design, operationalisation and performance of the four privatesector delivered AEAS models and ends with some recommendations.

\subsection{Design and operationalisation features}

Overall, we observe similarities and differences in the design and operationalisation features of the models (Table 27). We observe that all cases target commercial, entrepreneurial farmers, though of varying scales (small, mixed and medium) and either as individuals and/or as cooperatives/groups. The importance of clearly delineating client segments is noted to be key in innovating business models (Teece, 2010). However, this targeting does not include all producers; there are concerns that private sector enterprises that seek to stimulate market mechanisms to deliver AEAS are disadvantaging marginal (e.g. youth and women) or poor farmers (Birner et al., 2009; Feder et al., 2011). However, the models do have some women and youth as their clients, suggesting the need for more nuanced understanding of inclusion and exclusion.

In all cases, personalised on-farm visits is the dominant delivery method for advice, with generally low advisor:farmer ratios and frequency of visits. The models aim to use data-driven decision support methods and tools to provide an entire--farm advisory system that reinforces producers' capacities to manage their farms as enterprises. Accountability in supporting improvements can be part of the value proposition of these business models (Birner et al., 2009). However, all cases experienced challenges in operationalising the envisaged ICT/digitally enabled advisory tools and services, which has also been noted elsewhere (DLEC, 2019). Effective integration of ICT tools and systems still needs improvement. Finally, all models are designed to deliver a blend of complementary services and inputs, although the permutations vary.

Overall, the advisor:farmer ratios are observed to be low (ranging between 1:50 and 1:150) for the two cases that used a fixed ratio (MS and NKCC). The models set own qualification standards that are deemed as requisite for advisors to offer technical and managerial support to the clients. However, there has been a growing call for professional certification of advisors (GOK, 2017). Advisors are also expected to play additional roles related to growing the business, such as collecting extension fees, pushing uptake of inputs and sanctioning growers for non-compliance. For some, these roles stretched their capacities and illustrate that growing these business models requires entrepreneurship, which is not always part of advisors' professional training. This is an area for further consideration.

Another similarity is that all the cases mobilise diverse actors in an innovation ecosystem-like setting to contribute to the overarching value proposition. This partnership is pronounced in activities such as developing advisory content and tools, strengthening the capacity of advisors and enhancing horizontal coordination among clients. The actors mobilised span private, non-profit and public sectors. This indicates the business partners' appreciation of the dispersed nature of knowledge, technologies and other expertise among different actors.

We note that some models are more explicit in costing and pricing, which is critical in understanding the cost-effectiveness of the services offered. There was a mix of financing mechanisms: direct commercial fees, indirect user charges (levies or inbuilt in produce pricing) and subsidies, mainly involving development project (donor) projects. We observed that the cost of AEAS per client is not necessarily calculated at a rate commensurate with individual use, save for PAL. This confirms the lumpy nature and problems of AEAS noted by Carney (1998) that make it difficult to price services relative to use. 
Table 27: Comparative analysis of design features and performance of the four models

\section{Design features: provisioning/value creation}

Clients and targeting

Product/service development and delivery$$
\begin{aligned}
& \text { Small-scale mixed-crop } \\
& \text { (mainly as individuals) }
\end{aligned}
$$

Personalised, regular farm advice/support package; envisages use of historical set of farn data; facilitates access to quality complementary inputs; plans to facilitate access to produce markets

Profile of advisors Degree/diploma holders; low ratio 1:150 (advisor:farmer require blend of technical and business ratio, roles vs. skill development roles sets)

Key partners

Agrochemicals, universities and TVETs, Coops agrifood associations (GLOBALGA.P., NGOs COLEACP), management firms, research

\section{Design features: financing/value capture}

\begin{tabular}{ll} 
Costing & Intent is to make profit \\
pricing & Standard user charges (monthly) \\
Main sources of & Donors, own capital/revenue, \\
financing & clients/commercial segment \\
\hline
\end{tabular}

\section{Performance from the supply-side perspective}

\section{Uptake of AEAS \& High for AEAS; below targets for} complementary complementary services

services

Financing of AEAS Poor due to low recovery of and extended discount on AEAS fees and low uptake of complementary inputs against ambitious KPIs

Small-scale mixed crops commercial farmers (as individuals and in groups)

Personalised and group-based comanagement support to meet export market requirements; limited use of historical farm data; supplies and prefinances inputs and aggregates produce

Certificate/diploma holders; ratio not explicit; require mainly technical, business and grower relation roles

Agrochemicals, agrifood associations (GLOBAL extension, grower groups

\section{Not explicit}

Not explicit

Donors, own capital/revenue, growers/commercial segment

Moderate for AEAS, complementary services hampered by lack of targets

Difficult to analyse due to lack of explicit costing, but proxy indicators suggest poor performance

Proxy indicators suggest suboptima performance (i.e. volume exported)

Benefits of AEAS Model still at start-up phase, but financial

\section{Performance from the demand-side perspective}

Implementation of High and associated with increased demand advice for external inputs and labour

Changes in yield Early to evaluate changes; however, data indicate higher than national average results
Moderate and associated with high demand and right use of external inputs

Data suggest most growers experienced some improvements

Commercial medium-scale dairy farms Commercial dairy farmers, mixed (as individual farms) scales (as individuals and in groups)

Distinct advisory products (on-farm or Personalised regular farm visits and off-farm); shifting towards historical set group-based approaches; envisages of farm data and KPIs; intended to be use of historical set of farm data; neutral on complementary services but facilitates linkages for inputs and gradually facilitates linkages aggregates (raw milk) produce

Degree holders in diverse fields; ratio is Certificate/diploma holders initially flexible; attempts an internal professional certification; require on commission basis; low ratio specialisation related roles

International knowledge partners from Public extension, NGOs, dairy ic Dutch dairy industry, local universities, coops, agri-input companies, public research and NGOs. research, universities and TVETs

Intent is to make profits

User charges based on extent of use Levy-based milk supplied Donors, own capital/revenue, institutional and farmer segments Extension levy/milk suppliers, donors

Increasing but analysis hampered by lack of targets

Growth in revenue and sources however, KPIs are missing and farmer segment does not meet full costs Positive trend in turnover but unable to sustain the firm financially

High, though based on a small sample Rated as high

Average yield of 18 liters is more than Average yield of 9 liters is slightly double the national average, but falls above national average range, short of own targets
Decline for AEAS; below target for complementary services

Poor due to decline in milk levy and costing and fund management issues in accountability and delays

Poor due to variations in raw milk intake and a net decline over time falls short of models' targets. 


\subsection{Performance from the focal firms' business perspective}

Overall, the assessment findings suggest mixed and inconclusive results on the key business performance parameters evaluated (Table 27). However, the robustness of analysing such performance was challenged mainly due to lack of KPIs, arbitrary (and ambitious) targets and lack of consistent data sets.

In terms of uptake of AEAS and other complementary inputs and services being facilitated, MS and PAL reported progress in uptake of AEAS with a growing client base, NKCC experienced a good start followed by a decline, and Instaveg had no clear indication of uptake performance due to limited data.

The findings suggest suboptimal performance in financing and revenue generation, which is linked to costing of services, across all cases. For independent models (MS and PAL), the ultimate KPI is growth in profits; for chain-embedded models (NKCC and Instaveg) it is increased and more stable supply of fresh produce. The financial sustainability of the AEAS models is arguably dependent on the performance of the focal firms' core businesses, and the scalability of the AEAS on sustainability of the financing mechanisms. Overall, the key drivers of high costs of provisioning are low advisor:farmer ratios, high frequency of visits (two per month) and limited progress in leveraging digital technologies to reduce delivery costs. Costing and pricing of AEAS seems to be a blind spot except for PAL's approach of pricing distinct products. The full costs of delivering services that include the cost of advisors, their mobility and their communication costs are high - $14 \%$ to $65 \%$ of total advisor costs yet this seems overlooked. The costing and financing aspects are less transparent in chain-embedded models, as costs are recovered either indirectly and/or are disproportionate to usage. Direct user charges seem a challenging strategy to implement, particularly if there is no link to output markets through which cost can be recovered through modalities such as check-off.

\subsection{Performance from farmer clients' perspective}

Surveyed clients report moderate to high rates of implementing the advice provided by the focal firms. Implementation of recommended advice is associated with increased demand for external inputs and labour, especially in the horticulture models. Moreover, some of the improvements in farm management practices reported by survey respondents relate to adoption of precision farming practices, such as use of farm-specific diagnostics (e.g. use of on-farm data, soil analysis) to inform decisions, proper use of inputs, timely harvesting and traceability mechanisms (for Instaveg model), formulating on-farm feed rations and switching to milking machines. However, use of mobile phones to access farming advice was reported to be low to moderate, especially among smallholder-focused models. Limitations cited for low uptake relate to proficiency, access to smart phones, operating costs, low levels of being able to trust authenticity of information and hidden costs of access.

Closing the yield gaps between field averages and recommended potential targets is widely acknowledged as offering the most immediate pathway to achieving farm-level economic efficiency gains. Most clients surveyed for this assessment report either some improvements in yield or yield levels that are above national averages. Most, however, reported that they have not achieved the recommended yield targets.

\subsection{Recommendations}

The assessment illustrates examples of diverse private sector AEAS models that have emerged as part of the transforming agrifood sector in Kenya. The synthesis of the four cases highlights similarities and differences in the design and operationalisation of the models. Performance of these private-sector market-led models is mixed. From the perspective of business model innovation literature, the findings indicate that the models still need to work towards an optimal balance between value creation and value capture. From the perspective of AEAS, it means an optimal balance between provisioning modalities and financing mechanisms.

Based on the above insights we present several recommendations that can inform efforts to fine-tune the design and performance issues of the models, if scaling and sustainability are to be achieved. We 
group them into two categories: issues that the focal firms can address, and issues that require the intervention of the public sector and development partners/donor community.

\section{Recommendations for the focal firms}

1. Get the financing model right and adjust provisioning modalities accordingly: Unlike conventional business models that are based on commercial revenue streams from clients, these AEAS models have to explore a hybrid between commercial financing and alternative financing mechanisms (public-private partnerships, private partnerships, donor funding). Getting the financing (model) mechanisms right should be the most critical element driving the design and evolution of AEAS business models. Generally, the independent models seem more attuned to anchoring their business model innovation process on financing than the chain-embedded models. Based on the findings of this assessment, key attention areas under this recommendation are:

a. Invest in robust costing and pricing mechanisms for AEAS and other bundled services to fully cover costs and generate revenue (profit) where necessary.

b. Articulate the key financing mechanisms to be pursued and use measurable implementation and performance targets.

c. Continuously monitor and reconfigure provisioning modalities to align with financing opportunities and dilemmas (realities). This assessment finds low advisor:farmer ratios and regular farm-based advisory visits as key drivers of cost of delivery.

d. Devise effective mechanisms for capturing value, especially for the commercial segment. Direct user charges are not very effective except for PAL, with its MSF focus. For chainembedded cases (where indirect user charges and levies are applied) these mechanisms should also prioritise transparency and accountability measures.

2. Explore opportunities in stronger integration of digital extension technologies, to reduce costs of delivery and improve quality and outreach: The dividends of the unfolding digital revolution are expected to offer far-reaching opportunities for accelerating agricultural transformation (Klerkx et al., 2019). It has been suggested that digitising AEAS offers prospects for greater cost-effectiveness and privatisation of advisory services (Anderson, 2020). However, this assessment finds slow progress in leveraging ICT-enabled advisory tools and services.

3. Linking farmer/clients to stable and gainful output markets matters: A lesson from the dramatic decline in performance of the NKCC model is that uncertainties in prices and market conditions can drastically undermine a hitherto promising AEAS model even though assuring markets for farmers' produce is a specific entry point for embedding AEAS in output aggregation firms.

\section{Recommendations for the public sector and development partners}

4. The public sector needs to carve out its unique role in addressing some of the challenges that have been echoed in this assessment, primarily in regulation, development and vetting of advisory content, investment in human resource development systems that can produce extension agents fit for purpose, in financing, and in enactment of responsive policy and institutional frameworks.

5. Arrange for structured rather than one-off financial and technical support from development partners, so that public-private partnership models can positively influence the design and performance of private AEAS models. 


\section{References}

Anderson, R. J. (2020). Agricultural Extension Policy: A 2020 Re-Vision. Rutgers University Feed the Future Policy Consortium.

Bebe, B. O., Mwangi, J. G., \& Ozor, N. (2016). Changes in Agri-Business Outcomes among the Dairy Beneficiaries of Contracted Extension Services Delivery Model in Kenya. Journal of Agricultural Extension 20 (1).

Birner, R., Kristin, D., John, P., Ephraim, N., Ponniah, A., Janvier, E., ... Marc, C. (2009). From Best Practice to Best Fit: A Framework for Designing and Analyzing Pluralistic Agricultural Advisory Services Worldwide. The Journal of Agricultural Education and Extension 15, 314-355.

Boma Safi. (2019). Preliminary Results of Design and Delivery of High Quality Enterprise Based Extension Services to Farmers in Embu County. Boma Safi, Extension Program.

Carney, D. (1998). Changing Public and Private Roles in Agricultural Service Provision. London: Overseas Development Institute.

CGE. (2019). County Integrated Development Plan (CIDP 2018-2022). Embu: County Government of Embu.

CGN. (2018). County Integrated Development Plan-2018-2023. Kapsabet: County Government of Nandi.

Creemers, J. (2017). Assessement of Interventions under SNV/KDMP 2017: Perfometer Agribusiness Limited. Nairobi: SNV.

DLECP--Developing Local Extension Capacity Project. (2019). Strengthening private sector extension and advisory services portfolio review. Washington DC: Developing Local Extension Capacity Project, USAID.

Faure, G., Toillier, M. H., Rebuffel, P., Moumouni, M. I., Pierre, G., \& Tallon, H. (2018). Advice to farm to facilitate innovation: between supervision and support. In G. Faure, Y. Chiffolean, F. Goulet, L. Temple, \& J.-M. Touzard, Innovation and development in agricultural and food systems. Montpellier: CIRAD.

Feder, G., Birner, R., \& Anderson, R. J. (2011). The private sector's role in agricultural extension systems: potential and limitations. Journal of Agribusiness in Developing and Emerging Economies 1 (1), 31-54.

Gautam, M., \& Anderson, J. R. (1999). Reconsidering the evidence of returns to T\&V extension in Kenya: Policy Research Working Paper 1098. Washington DC: the World Bank.

GOK-- Government of Kenya. (2017). Guidelines and standards for agricultural extension and advisory services. Nairobi: Ministry of Agriculture, Livestock and Fisheries.

GOK--Government of Kenya. (2012). National Agricultural Sector Extension Policy (NASEP 2). Nairobi: Government of Kenya.

Haggblade, S. (2011). Modernizing African agribusiness: reflections for the future. Journal of Agribusiness in Developing and Emerging Economies 1 (1), 10-30.

IDH--The Sustainable Trade Initiative. (2016). Service Delivery Models (SMDs): Insights for continous improvements and farm impact. The Sustainable Trade Initiative.

IFC--International Finance Corporation. (2014). Working with smallholders: a handbook for firms building smallholders supply chains - Version 1, Draft. Washington DC: The World Bank.

Kabasa, J. D., Kirsten, J., \& Minde, I. (2015). Implications of changing agri-food system structure for agricultural education and training in Sub-saharan Africa. Journal of Agribusiness in Developing and Emerging Economics 5 (2), 190-199.

Kibet, N., Lagat, J., \& Obare, G. (2019). Logistic regression analysis on factors influencing incomepoverty among smallholder French bean farmers in Kirinyaga County, Kenya. Journal of Development and Agricultural Economics 11 (12), 272-285. 
Kilelu, C. W., Klerkx, L., Leeuwis, C., \& Hall, A. (2011). Beyond knowledge brokering: an exploratory study on innovation intermediaries in an evolving smallholder system in Kenya. Knowledge Management for Development Journal 7 (1), 84-108.

Klerkx, L., Jakku, E., \& Larbarthe, P. (2019). A review of social science on digital agriculture, smart farming and agriculture 4.0: New contributions and future research agenda. NJASWageningen Journal of Life Sciences 90-91 (2019), 100315.

Lee van der, J., Klerkx, L., Bebe, B. O., \& Oosting, S. (2018). Intensification and upgrading dynamics in emerging dairy clusters in the East Africa Highlands. Sustainability 10 (11), 4324.

Mazao Safi. (2019). Mazao Safi Company Profile. Nairobi: TradeCare.

McCullough, E. P., \& Stamoulis, K. (2008). The transformation of agri-food systems globalization, supply chains and smallholder farmers. London: Earthscan and FAO.

Minai, J. M., Nyairo, N., \& Mbataru, P. (2014). Analysis of socio-economic factors affecting the coffee yields of smallholder farmers in Kirinyaga County, Kenya. Journal of Agricultural and Crop Research 2 (12), 228-235.

Murithi, W. B. (2008). 'Compliance with EUREPGAP standards: determinants, costs and implications on profitability among smallholder French beans exporters in Kirinyaga District, Kenya.' Master Degree Thesis, Agricultural and Applied Economics, Egerton University.

Muyanga, M., \& Jayne, S. T. (2008). Private Agricultural Extension System in Kenya: Practice and Policy Lessons. The Journal of Agricultural Education and Extension 14 (2), 111-124.

NKCC--New Kenya Cooperative Creameries. (n.d.). NKCC Milk procurement infrastructure, extension services, linkages to financial institutions and dairy service provision. Nairobi: NKCC.

Ngeywo, J., Basweti, E., \& Shitandi, A. (2015). Influence of gender, age, marital status and farm size on coffee production: A case of Kisii County, Kenya. Asian Journal of Agricultural Extension, Economics and Sociology 5 (3), 117-125.

Osterwalder, A., \& Pigneur, Y. (2010). Business model generation; A handbook for visionaries, game changers and challengers. Hobken, New Jersey: John Wiley \& Sons Inc.

Perfometer. (2018). Company Profile. Nairobi: Perfometer Agribusiness Limited.

Perfometer. (2019). Annual Report 2018 to KMDP: Performeter Agribusiness Limited. Nairobi: Perfometer Agribusiness Limited.

Poulton, C., \& Kanyinga, K. (2014). The Politics of Revitalising Agriculture in Kenya. Development Policy Review 32 (S2), 151-172.

Rosca, E., Arnold, M., \& Bendul, J. (2016). Business models for sustainable innovation: an emprirical analysis of frugal products and services. Journal of Cleaner Production 162 (Suppl.), S133S145.

Talmar, M., Walrave, B., Podoynitsyana, S. K., Holmstrom, J., \& Romme, L. G. (2018). Mapping, analyzing and desiging innovation ecosystems: the Ecosystem Pie Model. Long Range Planning.

Teece, D. J. (2010). Businesss models, business strategy and innovation. Long Range Planning 43, $172-194$.

Veldhuizen, L. R., Rappoldt, A., Bitzer, V., \& Mur, R. (2018). Understanding agribusiness-based advisory services: Findings of a learning trajectory. Amsterdam: KIT Royal Tropical Institute.

Yin, R. K. (2009). Doing case study research. 4th ed. Thousand Oaks: SAGE.

Zhou, Y. (2015). Kenya Horticultural Exporters: Linking Smallholders to Market. In Y. Zhou, \& C. S. Babu, Knowledge-Driven Development (Chapter 5). Switzerland: Syngenta Foundation for Sustainable Agriculture. 


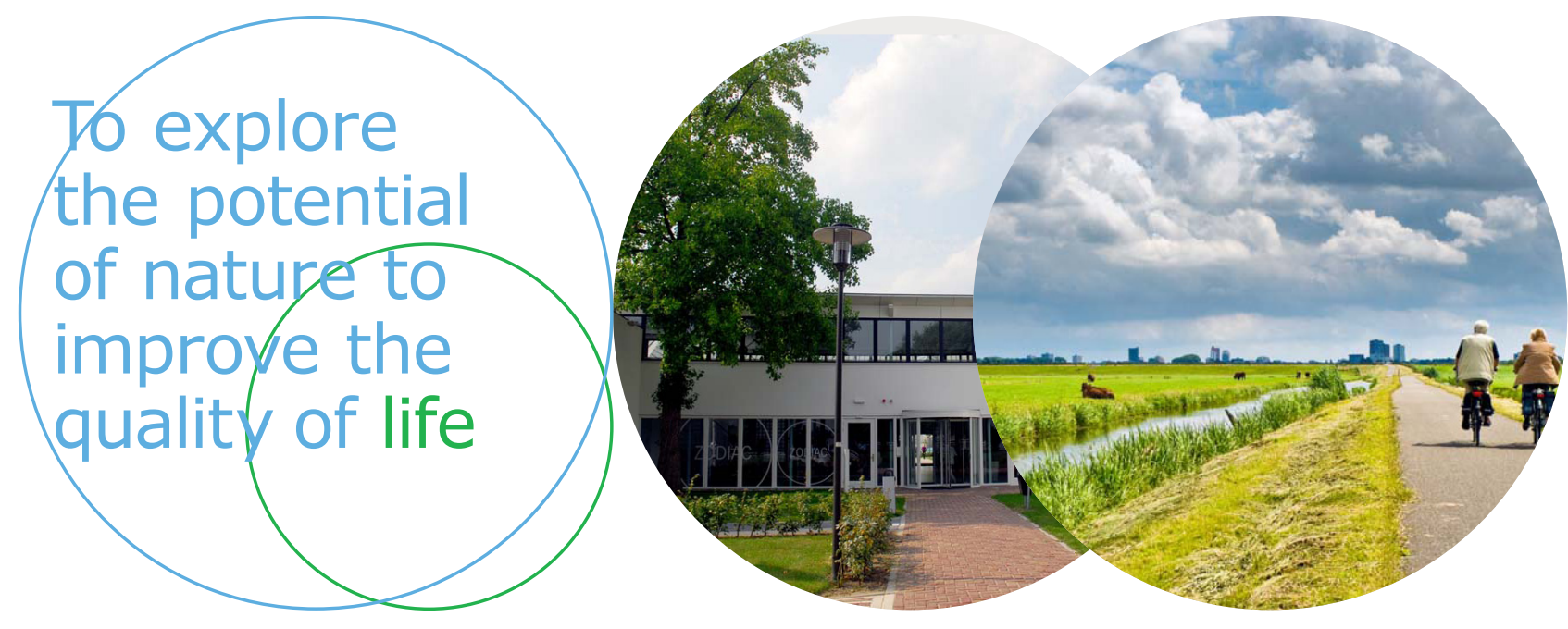

Wageningen Livestock Research P.O. Box 338

6700 AH Wageningen

The Netherlands

$\mathrm{T}+31(0) 317483953$

E info.livestockresearch@wur.nl

www.wur.nl/livestock-research

Wageningen Livestock Research creates science based solutions for a sustainable and profitable livestock sector. Together with our clients, we integrate scientific knowledge and practical experience to develop livestock concepts for future generations.

Wageningen Livestock Research is part of Wageningen University \& Research. Together we work on the mission: 'To explore the potential of nature to improve the quality of life'. A staff of 6,500 and 10,000 students from over 100 countries are working worldwide in the domain of healthy food and living environment for governments and the business community-at-large. The strength of Wageningen University \& Research lies in its ability to join the forces of specialised research institutes and the university. It also lies in the combined efforts of the various fields of natural and social sciences. This union of expertise leads to scientific breakthroughs that can quickly be put into practice and be incorporated into education. This is the Wageningen Approach. 